\title{
REDUCING INEQUALITY IN THE PEOPLE'S REPUBLIC OF CHINA THROUGH TAX AND FISCAL REFORMS
}

Dominik Peschel

NO. 46

December 2021
ADB EAST ASIA WORKING PAPER SERIES 


\section{ADB East Asia Working Paper Series}

\section{Reducing Inequality in the People's Republic of China through Tax and Fiscal Reforms}

Dominik Peschel

No. 46 | December 2021
Dominik Peschel is head of the Economics Unit at the Asian Development Bank's Resident Mission in the

People's Republic of China. 
(C) 2021 Asian Development Bank

6 ADB Avenue, Mandaluyong City, 1550 Metro Manila, Philippines

Tel +632 8632 4444; Fax +63286362444

www.adb.org

Some rights reserved. Published in 2021.

Publication Stock No. WPS220008-2

DOI: http://dx.doi.org/10.22617/WPS220008-2

The views expressed in this publication are those of the authors and do not necessarily reflect the views and policies of the Asian Development Bank (ADB) or its Board of Governors or the governments they represent.

ADB does not guarantee the accuracy of the data included in this publication and accepts no responsibility for any consequence of their use. The mention of specific companies or products of manufacturers does not imply that they are endorsed or recommended by ADB in preference to others of a similar nature that are not mentioned.

By making any designation of or reference to a particular territory or geographic area, or by using the term "country" in this document, $A D B$ does not intend to make any judgments as to the legal or other status of any territory or area.

This work is available under the Creative Commons Attribution 3.0 IGO license (CC BY 3.0 IGO)

https://creativecommons.org/licenses/by/3.0/igo/. By using the content of this publication, you agree to be bound by the terms of this license. For attribution, translations, adaptations, and permissions, please read the provisions and terms of use at https://www.adb.org/terms-use\#openaccess.

This CC license does not apply to non-ADB copyright materials in this publication. If the material is attributed to another source, please contact the copyright owner or publisher of that source for permission to reproduce it. ADB cannot be held liable for any claims that arise as a result of your use of the material.

Please contact pubsmarketing@adb.org if you have questions or comments with respect to content, or if you wish to obtain copyright permission for your intended use that does not fall within these terms, or for permission to use the ADB logo.

Corrigenda to ADB publications may be found at http://www.adb.org/publications/corrigenda.

Notes:

In this report, "\$” refers to United States dollars, and "CNY" refers to Chinese yuan.

ADB recognizes "China" as the People's Republic of China.

The ADB East Asia Working Paper Series is a forum for stimulating discussion and eliciting feedback on ongoing and recently completed research and policy studies undertaken by the East Asia Department of the Asian Development Bank (ADB) staff, consultants, or resource persons. The series deals with key economic and development problems, as well as conceptual, analytical, or methodological issues relating to project/program economic analysis, and statistical data and measurement. The series aims to enhance the knowledge on Asia's development and policy challenges; strengthen analytical rigor and quality of ADB's country partnership strategies, and its subregional and country operations; and improve the quality and availability of statistical data and development indicators for monitoring development effectiveness.

The ADB East Asia Working Paper Series is a quick-disseminating, informal publication whose titles could subsequently be revised for publication as articles in professional journals or chapters in books. The series is maintained by the East Asia Department. 


\section{CONTENTS}

Tables and Figures $\quad$ iv

$\begin{array}{lcl}\text { Acknowledgments } & \text { vi }\end{array}$

Currency Equivalents vii

Abbreviations $\quad$ vii

Executive Summary viii

$\begin{array}{ll}\text { I. Introduction } & 1\end{array}$

II. Inequality in the People's Republic of China 4
A. Overview
B. Income Inequality 5
C. Wealth Inequality 12
D. Regional Differences 16
$\begin{array}{ll}\text { E. Reform Needs } & 18\end{array}$

III. Tax Reforms to Reduce Inequality $\quad 19$
A. Taxes to Reduce Inequality 19
B. Personal Income Tax 21
C. Recurrent Property Tax $\quad 22$
D. Inheritance and Gift Taxes $\quad 25$

$\begin{array}{ll}\text { IV. } & \text { Reforming Intergovernmental Fiscal Relations }\end{array}$

A. A Bird's-Eye View of Fiscal Arrangements 28

B. Mounting Reform Pressure $\quad 31$

C. Fiscal Expenditure Responsibilities $\quad 34$

D. Fiscal Transfers 36

E. Local Government Fiscal Revenue $\quad 40$

F. Implementing Fiscal Reforms 46

$\begin{array}{ll}\text { V. Summary of Recommendations } & 47\end{array}$

$\begin{array}{ll}\text { References } & 49\end{array}$ 


\section{TABLES AND FIGURES}

\section{Tables}

1 Recommended Further Personal Income Tax Reforms 22

2 Summary of Recommended Steps for a Recurrent Property Tax 25

3 Recommendations on Inheritance and Gift Taxes 27

4 Summary of Recommendations for Tax and Fiscal Reforms 47

\section{Figures}

1 Inequality and Policy Interventions 2

2 Income Inequality before and after Redistribution 5

3 Top 10\% and Top 1\% Pretax National Income Share, 1980-2019 6

4 Income Gini Coefficient 6

5 Income Distribution, 1980-2015

6 Pretax National Income by Decile, 2000, 2010, and 2015

7 Disposable Income Per Capita by Income Level, 2013-2020 8

8 Share of Population Ages 15-59 and Labor Force, 2005-2020 9

9 Average Wage Growth for Workers in High- and Low-Skill Sectors, 2004-2020 9

10 Growth in Disposable Income Per Capita, 1980-2020 10

11 Ratio of Urban to Rural Per Capita Disposable Income, 1980-2000 10

12 Disposable Income of Urban and Rural Residents by Source, 2013 and 202010

13 Wealth Gini Coefficient, 1981-2020 12

14 Wealth Distribution, 1995-2015 12

15 Top 10\% and Top 1\% Wealth Share, 1980-2015 13

16 Price Increases for Newly Constructed Homes, 2011-2021 14

17 Average Selling Price Increase of Residential Property in Tier 1 and 2 Cities 14

18 Home Purchase Price-to-Income Ratio in Selected Cities, 2015 and 2019

19 Real Growth in Gross Regional Product by Region, 2000-2020 16

20 Gross Regional Product Per Capita, 2000, 2010, and 201916

21 Fiscal Expenditure by Province and Gross Regional Product Per Capita, 2019

22 General Government Fiscal Revenue, 2019 (\% of GDP) 19

23 Marginal Personal Income Tax Rate 20 
24 Average Personal Income Tax Rate 20

25 Government Fiscal Expenditure and Revenue, 1980-2020 28

26 General Government Fiscal and Tax Revenue versus Fiscal Expenditure, 1985-2020 29

27 Local Government Fiscal Imbalance, 1980-2020 29

28 Central and Local Government Fiscal Balance before Transfers, 1980-2020 29

29 Central Government Fiscal Transfers to Local Governments, 1990-2020 30

30 Local Government Fiscal Balances after Transfers, 201930

31 Government Debt, 2006-2020 31

32 Outstanding Local Government Debt by Province, 2019

33 Fiscal Transfers as Percentage of Local Government Fiscal Gap, 1994-2020 32

34 Fiscal Transfers as Percentage of Fiscal Revenue and Expenditure, 2007-2020 32

35 Central Government Fiscal Revenue and Transfers versus Nominal Gross 32 Domestic Product, 1995-2000

36 Public Debt and Gross Regional Product Per Capita by Province, 201933

37 Public Debt and Fiscal Balance after Transfers by Province, 201933

38 Breakdown of Local Government Fiscal Expenditure, 2007-2019 35

39 Top 10 Central Government Fiscal Expenditure, 2020 (\% of total expenditure) 35

40 Fiscal Transfers to Provinces and Gross Regional Product Per Capita, 2019

41 Breakdown of Central Government Fiscal Transfers by Type, 1995-2018 38

42 Breakdown of Central Government Fiscal Revenue, 2019 (\% of GDP) 40

43 Breakdown of Local Government Fiscal Revenue, 2019 (\% of GDP) 40

44 Tax Revenue by Province and Gross Regional Product Per Capita, 201942 


\section{ACKNOWLEDGMENTS}

Insightful comments were provided by Yolanda Fernandez Lommen, country director, People's Republic of China Resident Mission, Asian Development Bank (ADB); Safdar Parvez, advisor, Akiko TeradaHagiwara, principal economist, and Peter Rosenkranz, economist, East Asia Department, ADB; Marcel Schroder, economist, Economic Research Department, ADB. Valuable research assistance was provided by Wen Qi, associate economics officer, People's Republic of China Resident Mission, ADB, and Huiyan Du, former ADB consultant. 


\section{CURRENCY EQUIVALENTS}

(As of 30 November 2021)

Currency unit - CNY

CNY1.00 $=\$ 0.157$

$\$ 1.00=$ CNY 6.388

\section{ABBREVIATIONS}

$\begin{array}{ll}\text { CIT } & - \text { corporate income tax } \\ \text { COVID-19 } & - \text { coronavirus disease } \\ \text { IMF } & - \text { International Monetary Fund } \\ \text { GDP } & - \text { gross domestic product } \\ \text { GRP } & - \text { gross regional product } \\ \text { NBS } & - \text { National Bureau of Statistics } \\ \text { OECD } & - \text { Organisation for Economic Co-operation and Development } \\ \text { PIT } & - \text { personal income tax } \\ \text { PRC } & - \text { People's Republic of China } \\ \text { US } & - \text { United States } \\ \text { VAT } & - \text { value-added tax } \\ \text { WTO } & - \text { World Trade Organization }\end{array}$




\section{EXECUTIVE SUMMARY}

Income inequality after redistribution remains high in the People's Republic of China (PRC), as does wealth inequality. No gift and inheritance taxes are in place and personal income tax (PIT) focuses on wage income, thereby neglecting capital income. High and rising housing prices, and the absence of a nationwide recurrent property tax, aggravate the issue. One reason for the high level of inequality is a lack of redistribution: at the individual level, redistribution through PIT and public transfers is very limited; at the regional level, fiscal arrangements have left many local governments with increasing fiscal imbalances and rising debt. The level of fiscal-expenditure decentralization in the PRC is one of the highest in the world. It manifests itself in sizable regional differences in the delivery of public services and social security benefits.

This paper discusses policy options for taxes and fiscal transfers to tackle income, wealth, and interprovincial inequality.

On the tax side, recommendations relate to three areas: (i) further PIT reforms, (ii) rolling out a nationwide recurrent property tax, and (iii) introducing inheritance and gift taxes.

(i) PIT reforms include measures to strengthen the tax base as well as to improve PIT progressivity and compliance. Recommendations to strengthen the tax base include limiting special deductions while including individual business income, pensions, annuities, and capital gains into comprehensive income. The inclusion of more categories of income into comprehensive income would also increase PIT progressivity. Tax withholding and reporting needs strengthening.

(ii) A nationwide rollout of a recurrent property tax needs a legal basis that delegates specific taxation power and responsibility to local governments. A nationally standardized tax base must be defined and a moderate tax rate set (with few exemptions). Local governments must gain the capacity to use the property registry for valuation purposes.

(iii) As income is currently taxed but wealth is not, inheritance and gift taxes should be introduced at progressive rates beyond specific tax-free amounts for close relatives. For these taxes, the property tax registry could be used to determine the tax base.

Given the significant and growing gap between fiscal expenditure and revenue at the local level, reforms of central-local government fiscal relations should focus on (i) revisiting and, where adequate, reassigning fiscal expenditure responsibilities, (ii) enhancing the fiscal transfer system, and (iii) strengthening local government fiscal revenue. Recommendations include:

(i) Responsibility for public pensions and unemployment insurance should be elevated to the level of central government in line with international best practices. More broadly, fiscal expenditure responsibilities should be clearly delineated, and the scope of joint responsibilities reduced.

(ii) Higher transfers from the central government to poorer local governments are needed with a strong focus on increasing transfers to poorer provinces to limit the financial burden for the central government. While shared-function transfers for basic public services should be increased, budget management at the local level and the evaluation of these services must be strengthened. In addition, subprovincial transfers should be formalized.

(iii) Local government fiscal revenue must be strengthened by a recurrent local property tax as own-source revenue at the local level, broadening the PIT base, and introducing gift and inheritance taxes. Levying a local surcharge on PIT should also be considered or the tax sharing system could be revisited to fine-tune local government revenue. 


\section{INTRODUCTION}

Inequality remains relatively high in the People's Republic of China (PRC), and, without policy intervention, will likely rise in the future. ${ }^{1}$ This paper analyzes income and wealth inequality, and per capita gross regional product (GRP) at the provincial level. It discusses policy options for different taxes and fiscal transfers to tackle inequality. Income inequality peaked at the end of the first decade of the 2000s and has lessened somewhat since then, but lack of data has made it harder to get a clear picture of the situation since the mid-2010s. A challenge specific to the PRC is the absence of effective redistribution via taxes and public transfers. Personal income tax (PIT) needs further reforms to become more effective in reducing inequality and for raising more revenue, which was the equivalent of $1.1 \%$ of GDP in 2019, far below the average of Organisation for Economic Co-operation and Development (OECD) countries, at 8.1\% in 2018 (OECD 2020).

Wealth inequality is high in the PRC and the absence of taxes keeping the concentration of wealth in check-inheritance and gift taxes, capital gains taxes, and nationwide recurrent taxes on immovable property-facilitates this concentration. These taxes need to be implemented.

Since the mid-2000s, some gradual regional convergence has taken place as economic growth in the central and western regions outpaced the wealthier eastern region. At the same time, regional differences in the delivery of basic public services and social security benefits remain pronounced. Reforms of intergovernmental fiscal relations are needed to ensure that poorer provinces continue to catch up and do not fall behind in economic development and living standards.

This paper's recommendations on reforming both taxation and intergovernmental fiscal relations provide a roadmap for reforms and highlight the connection between proposed reforms, which should help foster policy consistency.

Tackling inequality is complex. Income and wealth inequality cannot be separated-high-wealth individuals tend to have higher income as capital generates income. High property prices and rising rents in the PRC's big cities have become a social issue. In the labor market, wage polarization has contributed to inequality in recent years, while manufacturing jobs are on the decline as rising wages have resulted in some outsourcing to countries in Asia with lower labor costs. Population aging will increase the need for more health and other care services and put pressure on public pensions, which are a local government responsibility in the PRC. And local governments, for their part, face severe funding gaps and rapidly rising debt.

Tackling inequality needs a more comprehensive approach than simply adjusting PIT rates at the margin. Policy adjustments are needed in many areas, which must be consistent and, ideally, reinforce each other. For taxation and intergovernmental fiscal relations, this paper offers a set of inequality-reducing reforms that complement each other. Taxes not only redistribute income (or tax wealth) but also account for the bulk of fiscal revenue. Higher tax revenue is needed to fund transfers. In the context of the PRC, one way of transfers is improving the provision of public health services, education, and social security-all of which affect income. Because local governments are mainly responsible for these services and also provide social security benefits, fiscal transfers to poorer regions are needed to help fund these services and benefits.

\footnotetext{
Income inequality in the PRC is high for a country approaching high-income status according to World Bank (2021).
} 
Figure 1 gives an overview of the mechanisms (thin arrows) and policy interventions (thick arrows), mostly mitigation measures, discussed in this paper. ${ }^{2}$ The color coding corresponds to sections II, III, and IV in this paper that examine inequality (red), taxation (blue), and transfers (green).

\section{Figure 1: Inequality and Policy Interventions}

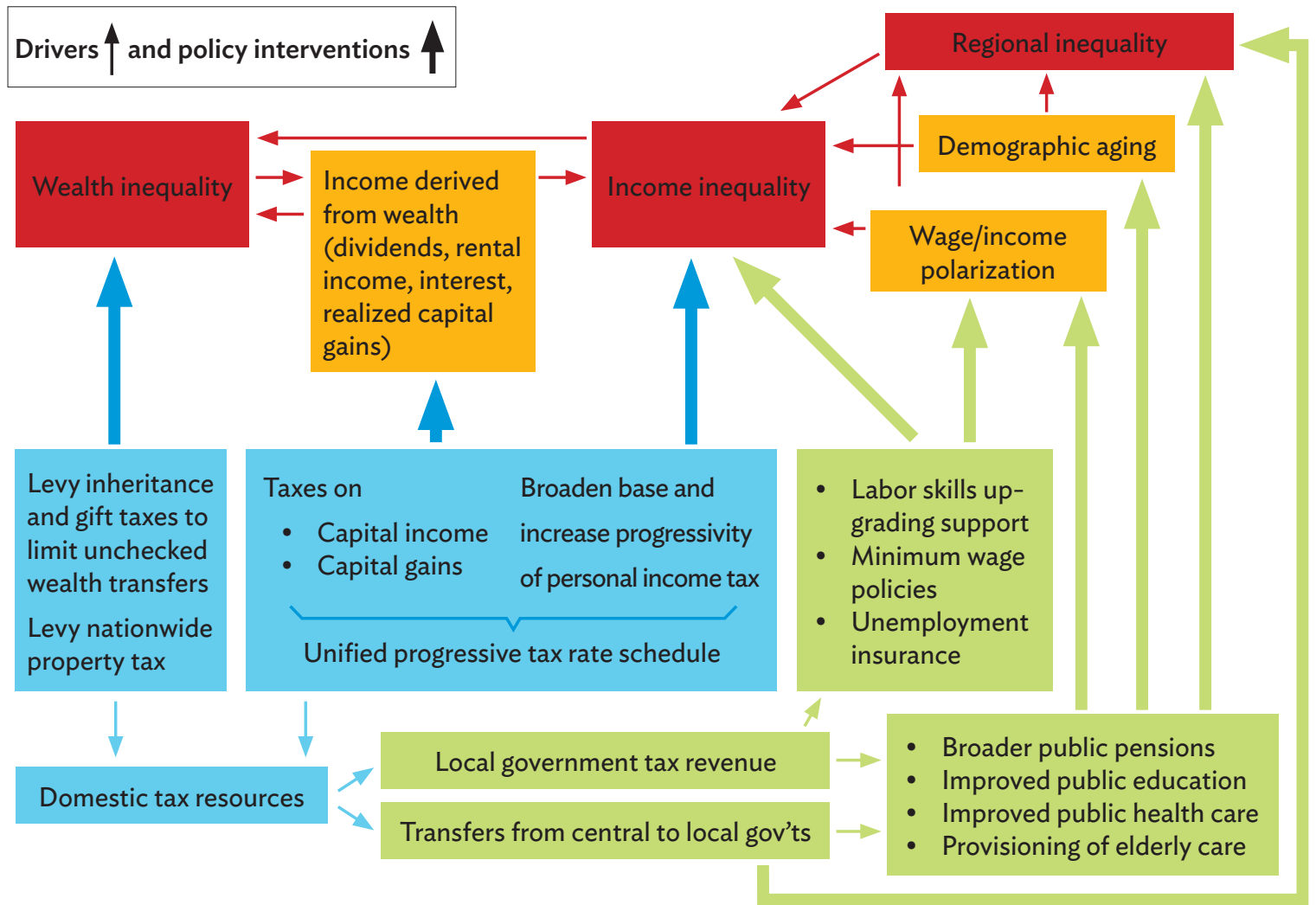

Source: Author.

Several factors, including skills and education, occupation, regional differences, demographics, and wage policies, contribute to income inequality (Figure 1). Taxation and public transfers can reduce this inequality, with progressive PIT mitigating inequality at the top and public transfers at the bottom. Income inequality can be exacerbated by wealth inequality, especially via nonwage income derived from wealth. Taxing wealth accrued from inheritance and levying nationwide recurrent property tax would mitigate wealth inequality, as would the progressive taxation of capital income-all of which are currently not in place in the PRC.

The PRC is highly decentralized in terms of fiscal expenditure, with local governments accounting for about $85 \%$ of total fiscal expenditure. Their revenue, however, has not been sufficient to cover their expenditure, resulting in a fiscal gap that is being partially filled by transfers from the central government. Local governments also shoulder almost the entire cost of providing basic public services, including

2 Some effects, such as the impact of demographics and wage polarization on regional inequality, are acknowledged, but they are not analyzed in depth in this paper because of data constraints. Wage polarization and population aging will affect some regions more than others given ongoing internal migration and geographic clusters of innovative industries. Central government employment assistance transfers to local governments are negligible. 
education and health care. And contrary to international practice, local governments are responsible for public pensions and unemployment benefits. Because of this, regional inequality affects individual income inequality beyond the job market via disparities among local governments in the delivery of basic public services and income maintenance. Thus, fiscal transfers from the central government to poorer regions can help mitigate income inequality, at least indirectly, at the individual level when these transfers are used to improve basic public service delivery and social security. ${ }^{3}$ Enhancing public health and education services provided at the local level to disadvantaged groups can help improve their income opportunities. General government expenditure on health is particularly low in the PRC compared with other upper-middle-income countries, and it is slightly below these countries on education expenditure (World Bank 2018).

Tax revenue, equivalent to $16 \%$ of GDP in 2019 , is shared between the central government and local governments. It not only finances fiscal expenditure at the local level but also provides the central government revenue needed to finance fiscal transfers to provincial administrations. ${ }^{4}$

The rest of this paper is structured as follows: Section II discusses the development of income and wealth inequality in the PRC, analyzes the drivers of this over the past decades, and examines differences between provinces. Section III discusses tax reforms to reduce inequality, particularly the further PIT reforms needed to tackle income inequality and the need to levy property, gift, and inheritance taxes to tackle wealth inequality. Section IV examines intergovernmental fiscal relations-focusing on expenditure responsibilities, fiscal transfers, and local government fiscal revenue-and the need for reform in this area. Section $\vee$ summarizes the paper's policy recommendations.

3 For example, Lardy and Huang (2020) point out the weakness of the PRC's unemployment insurance system: limited coverage, modest benefits, and few recipients, as only a tiny share of the unemployed receive benefits.

4 Province-level administration in this paper includes 22 provinces, five autonomous regions, and four centrally administered municipalities (Beijing, Chongqing, Shanghai, Tianjin). The PRC is administratively divided into four levels below the central level: provincial, prefectural, county, and township. See Wang and Herd (2013) for a detailed description of this. 


\section{INEQUALITY IN THE PEOPLE'S REPUBLIC OF CHINA}

\section{A. Overview}

Measuring inequality in the PRC is fraught with three main challenges. The first is the availability and quality of data. For income inequality, the time series of the Gini coefficient ${ }^{5}$ from the National Bureau of Statistics (NBS) starts only in the early 2000s and detailed income distribution data are not available from the NBS for the entire 2010s. Some scholars argue that the official data understate the income share of top earners, resulting in higher income inequality in reality (Piketty, Yang, and Zucman 2019; $\mathrm{Li}$, Li, and Wan 2020). Scholars working on inequality in the PRC also frequently use different data sets, thus potentially arriving at different conclusions. ${ }^{6}$

The time lags in the available data are the second challenge. Many findings on inequality in the PRC are derived from household surveys, which are only conducted after gaps of some years. While other countries face similar issues, this seems to affect findings for the PRC since the time series tend to be shorter, which makes it difficult to determine long-term trends. Kanbur, Wang, and Zhang (2020), using the Gini coefficient and cross checks, show that income inequality peaked at the end of the first decade of the 2000s. After a retreat in the first half of the 2010s, the Gini coefficient edged up in the second half of the decade. How inequality unfolded in the second half of the 2010s cannot be fully explained yet, but analysis of wage dynamics provides a piece of the mosaic (Rozelle et al. 2020), as discussed in section B.

For making policy recommendations, not only the level but also the trend in inequality is important. While there is sufficient evidence that income inequality after redistribution is high and warrants more redistribution, the trend is also important to determine the necessity and extent of policy interventions. In this context, demographics and wage polarization are the potential drivers of inequality in the future, which deserves analysis. Furthermore, the COVID-19 shock and its expected bigger impact on poorer households could deepen inequality.

The third challenge is the absence of reliable up-to-date data on wealth distribution. Wealth distribution is frequently difficult to estimate. In the PRC, the absence of related tax data is another hurdle. The country has no inheritance or gift taxes and no nationwide recurrent property tax. Capital gains by individuals are also generally not taxed. Hence, no respective tax data exist that can support findings on wealth distribution. But thanks to Piketty, Yang, and Zucman (2019), using combinations of available data, wealth distribution estimates are available until 2015. For after 2015, it is likely that a new wave of house-price increases affected wealth inequality (section C).

Inequality between different regions in the PRC is pronounced. Beijing and Shanghai have reached standards of living comparable to cities in developed countries, but other regions, especially in the poorest areas, still lag significantly behind in development. Because fiscal expenditure is extremely decentralized in the PRC, fiscal transfers need to be increased for lagging regions for them to be able to improve basic public services (section D).

5 The Gini index is a measure of inequality. A value of 0 indicates perfect equality; a value of 1 perfect inequality.

6 Kanbur, Wang, and Zhang (2020) provide a survey of inequality studies and their findings. Gustafsson, Li, and Sato (2014) compare different data sources. 


\section{B. Income Inequality}

This section compares income inequality in the PRC with that in other countries, discusses developments in and the drivers of inequality in the PRC, and examines demographic change and wage polarization as future drivers of inequality in the country.

\section{International perspective on income inequality}

When redistribution is taken into account, income inequality in the PRC is high compared with developed economies (Figure 2). The limited scope of PIT and the regressivity of social security contributions in the PRC contribute to this (Lam and Wingender 2015; Ahmad and van Rijn 2020). Many taxpayers only pay PIT at a low rate and anyway only the top quintile pay PIT, which helps explain the low degree of redistribution via taxes. ${ }^{7}$

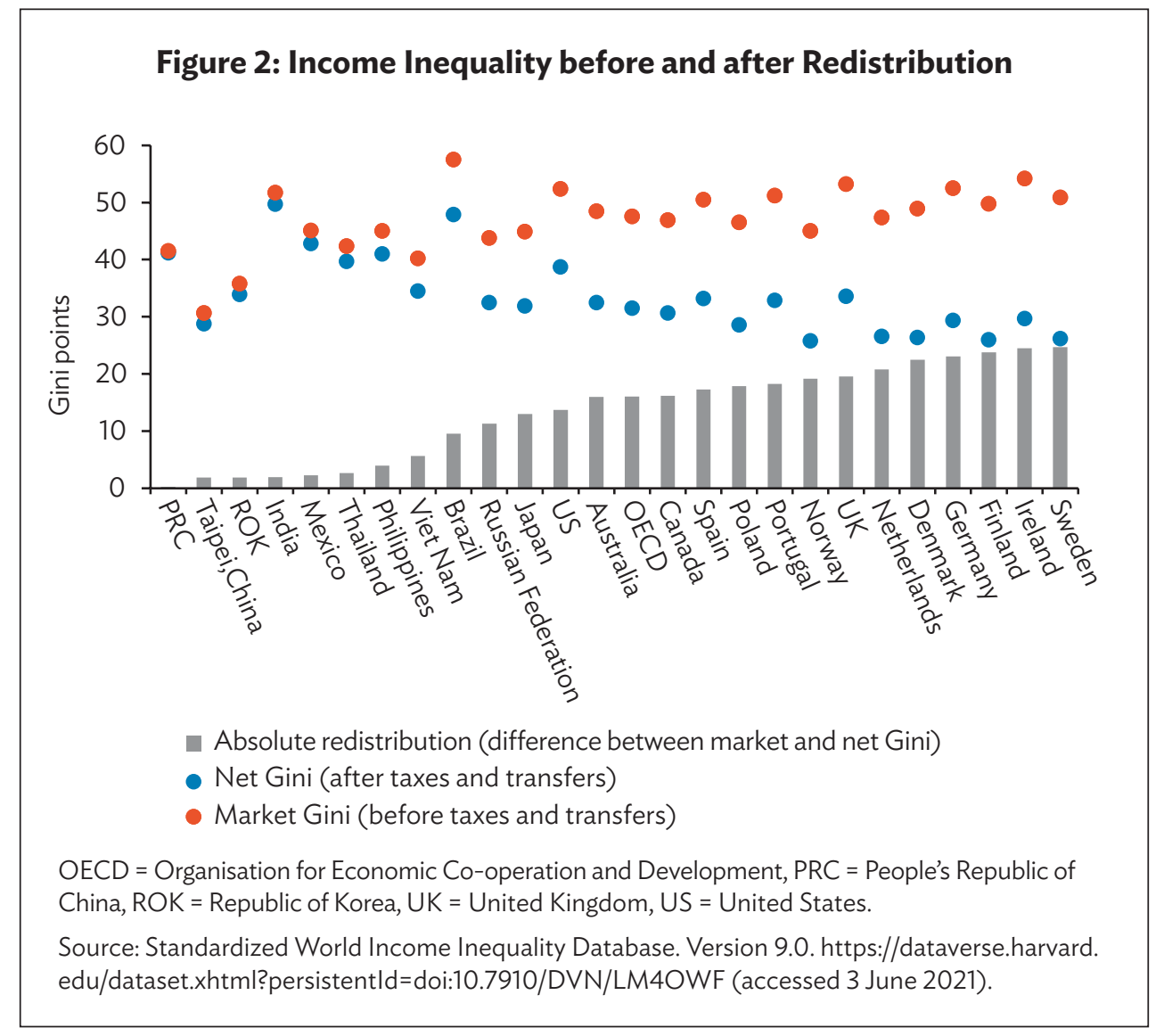

Advanced economies, as Figure 2 suggests, tend to redistribute income more than developing and emerging market ones (Bastagli, Coady, and Gupta 2015). A more progressive PIT regime can mitigate inequality at the top, while public transfers can reduce inequality at the bottom (BIS 2021). Empirical evidence suggests the inequality-reducing effect of transfers is frequently stronger than that of taxes. ${ }^{8}$

\footnotetext{
7 Applying the PIT rates after the 2018 reform to a 2013 household data set, OECD (2019) estimates that less than 1\% of taxpayers pay PIT at a rate of more than $10 \%$ and nearly $82 \%$ have a tax rate of zero, i.e., they do not pay PIT.

8 See Coady, de Mooij, and Shang (2015) for a set of 24 advanced economies and Inchauste and Lustig (2017) based on a set of eight low- and middle-income countries.
} 
Internationally, inequality is high in the PRC, with the top 10\% income share surpassing that of Group of Seven countries in the early 2000s. The PRC's income share is now close to Japan's but still below that of the United States (Figure 3). For the top 1\%, the pattern is similar, with their share sharply rising in the early 2000s after the PRC joined the World Trade Organization (WTO) (Figure 3).

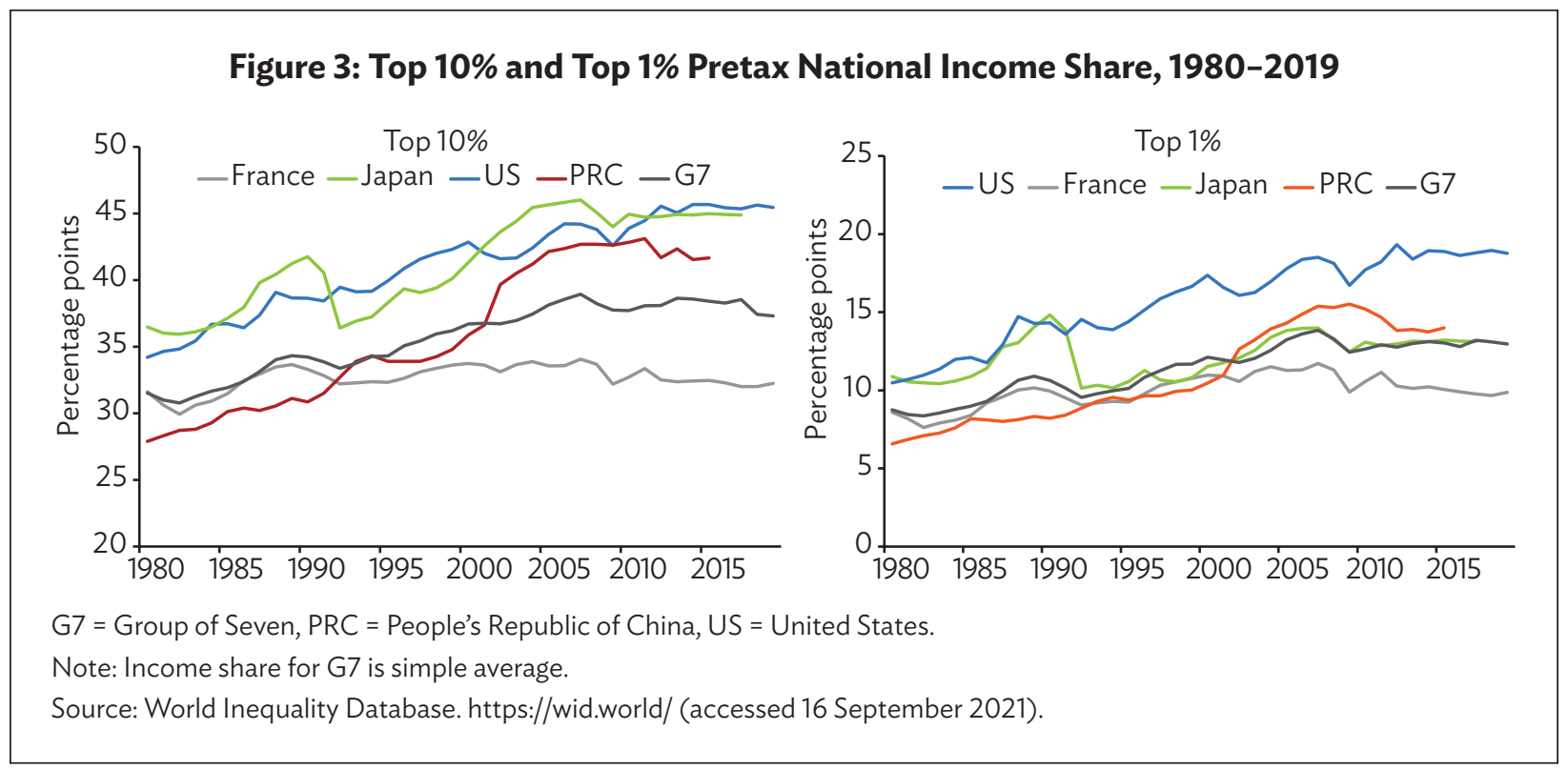

\section{Income inequality in the People's Republic of China}

Inequality increased in two waves in the PRC. The first started in the 1980s with market-oriented economic reforms; the second after the country joined the WTO in 2001. Income inequality increased up to 2008, when the Gini coefficient was nearly 0.5. It then declined moderately until 2015, reaching 0.46, before hovering around 0.47 over 2016-2019 (Figure 4).

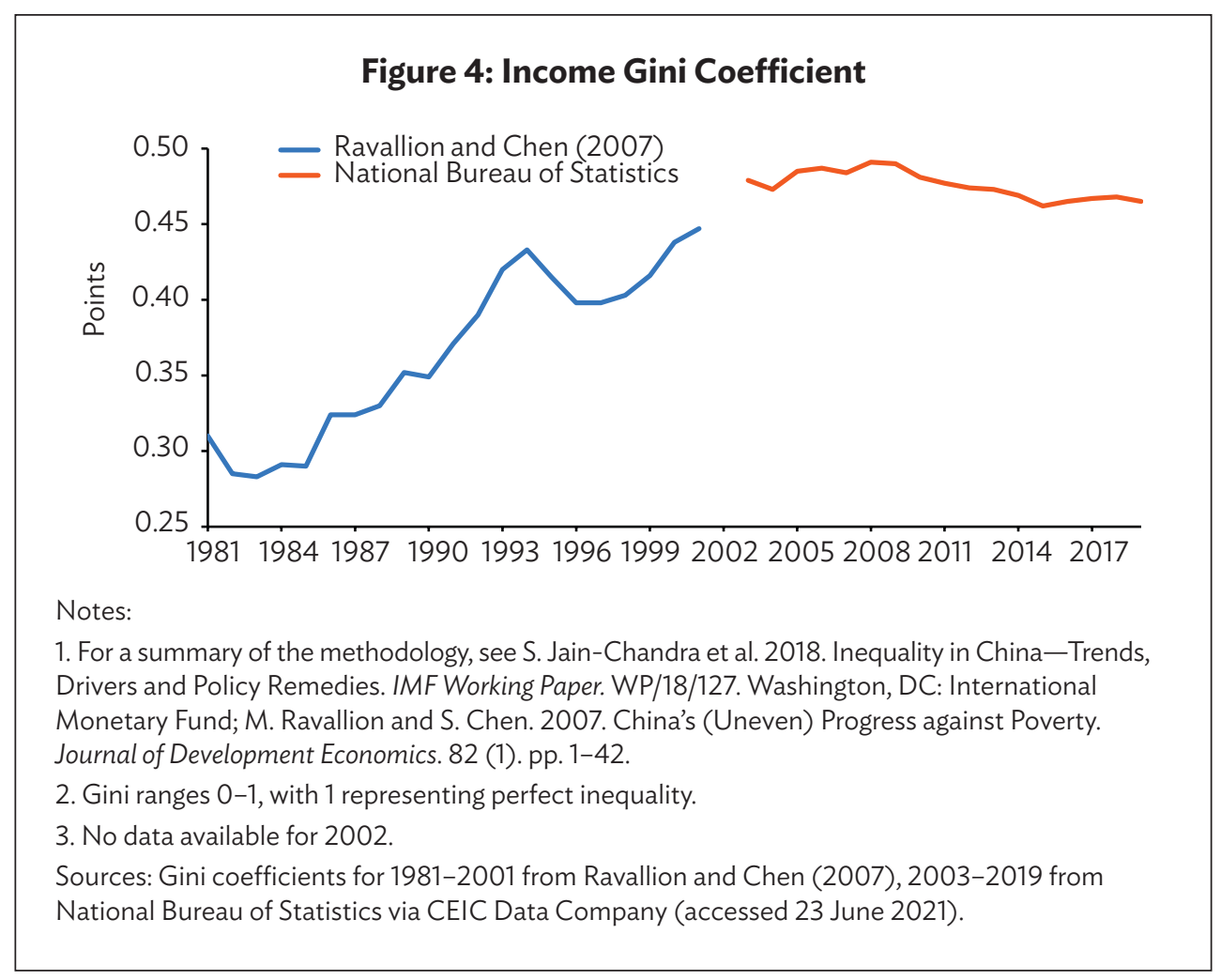


Kanbur, Wang, and Zhang (2020), using several data sources, corroborate that inequality has declined since the end of first decade of the 2000s. ${ }^{9}$ But some academics argue that the PRC's Gini coefficient underestimates the income of the top earners, implying that income inequality is actually higher (Piketty, Yang, and Zucman 2019; Li, Li, and Wan 2020).

The falling trend in the share of the bottom $50 \%$ in income distribution stabilized in the early 2010 s, the middle $40 \%$ even slightly increased, and the top 10\% slightly declined (Figure 5). Pretax income rose sharply in the first decade of the 2000s, with the top 10\% - the 10th decile in Figure 6-gaining the most. This trend continued until 2015, the year for which latest data are available.
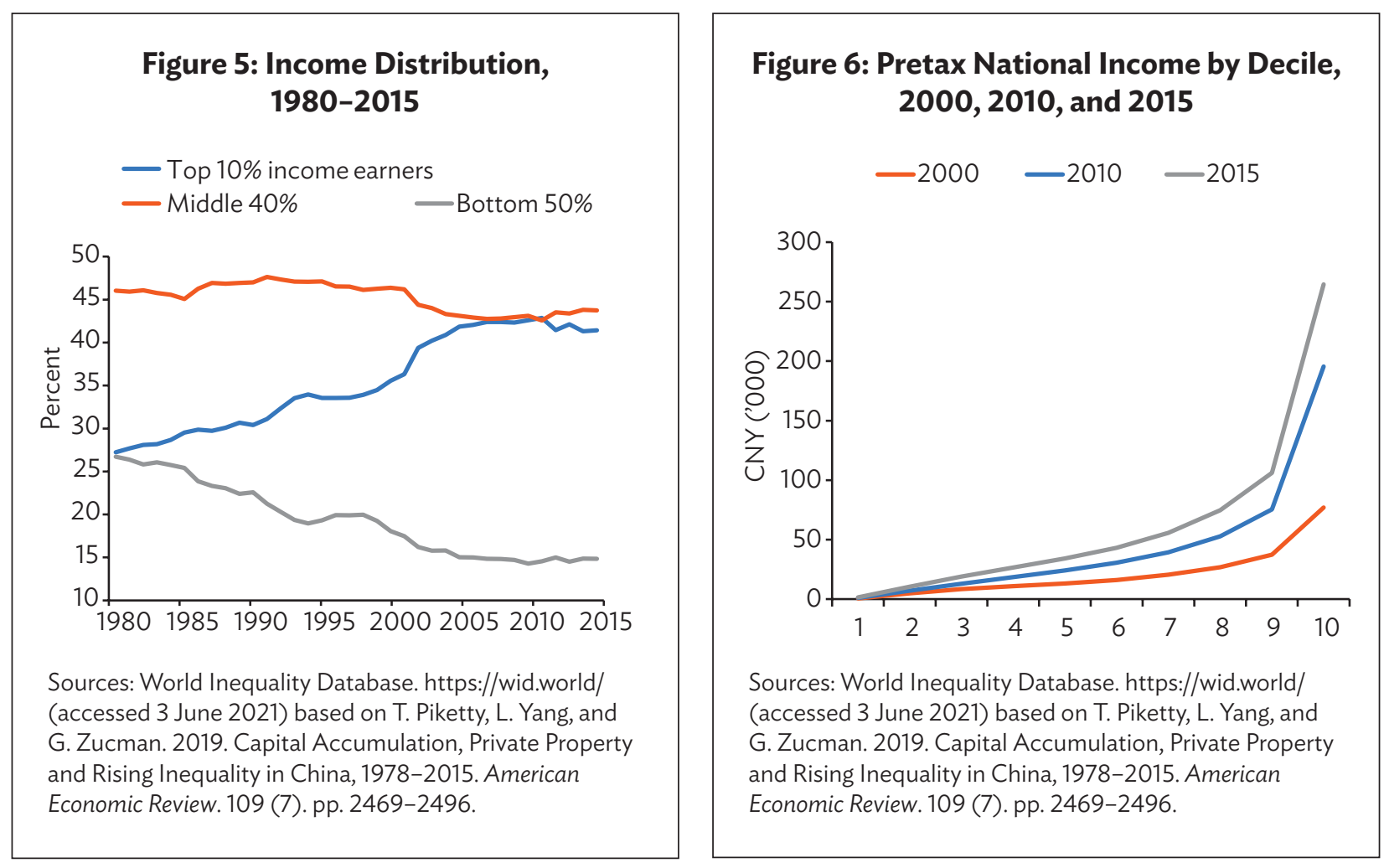

This, together with the lack of significant income redistribution via PIT and the low level of public transfers, explains why the distribution of disposable income has remained vastly inequal since consolidated data on disposable income per capita became available in 2013 (Figure 7). ${ }^{10}$ The ratio of the highest-to-lowest income quintile has stayed above 10 every year since then.

9 Data in Kanbur, Wang, and Zhang (2020) end in 2018.

10 The NBS has published annual income by quintiles since 2013. Before that, there were data challenges because of separate surveys for urban and rural areas; see Gustafsson, Li, and Sato (2014) on this. 


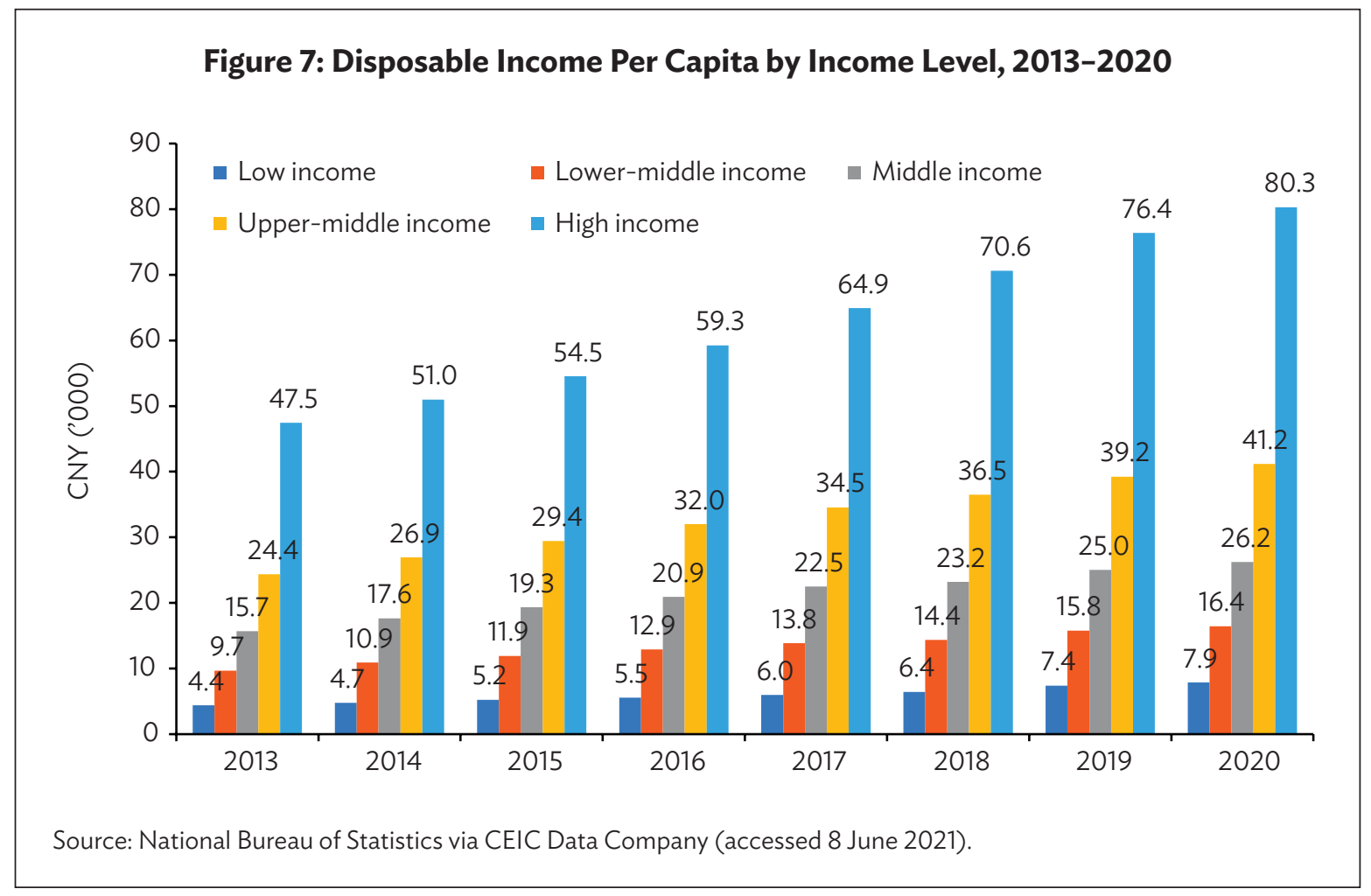

The shock of COVID-19 on the economy has likely worsened income disparities as the pandemic has disproportionally hit poorer households. ${ }^{11}$ The disposable income of the lowest quintile expanded by only $6.6 \%$ in 2020 , while that of the highest quintile outpaced the income of the other three quintiles (Figure 7). This finding is consistent with high-income white-collar workers being able to work from home. But COVID-19 hit low-income services jobs hard. NBS data show the average income of migrant workers, which account for slightly over half the workforce in the services sector, only increased by $2.8 \%$ in 2020, down from 7.8\% growth in 2019. The disposable income of the lowest quintile showed the fastest growth in 2020, which could be due to the concentration of this income group in rural areas, with their employment having potentially suffered less from frictions caused by COVID-19 mobility restrictions.

\section{Drivers of inequality}

Jain-Chandra et al. (2018) find that education and the skills premium, as well as the rural-urban gap, drove the increase in inequality from 1980 to 2008. Empirical evidence suggests the skills premium has moderated since then, which could be a result of the sharp increase in university graduates and strictly enforced rising minimum wages (Zhuang and Shi 2016; Jain-Chandra et al. 2018; Li, Sicular, and Tarp 2018).

Demographic shifts led to an aging and declining labor force, with the share of the working-age population (ages 15-59) peaking in 2011 and the labor force peaking in 2014 (Figure 8). ${ }^{12}$ As the PRC passed the Lewis turning point, ${ }^{13}$ less surplus labor came from rural areas (Das and N’Diaye 2014; Lam, Liu, and

11 For anecdotal evidence, see Yu and Yang (2020) and Leng (2020).

12 The legal retirement age is 60 years for men and 55 for women in white-collar jobs and 50 for women in blue-collar jobs, while the average actual retirement age is 54 (The Economist 2021a).

13 The Lewis turning point is characterized by less surplus labor from rural areas that leads to a rise in wages in industry. In a dual-sector economy (agriculture and manufacturing), the first stage of the migration of surplus labor from subsistence agriculture sees manufacturing expand without wage increases. With surplus labor from rural areas starting to dry up in the second stage, wages of migrant workers in manufacturing start to rise. 
Schipke 2015; Goodhart and Pradham 2020). The decline in the labor force has not, however, resulted in higher wage growth in low-skill sectors in recent years (Figure 9).
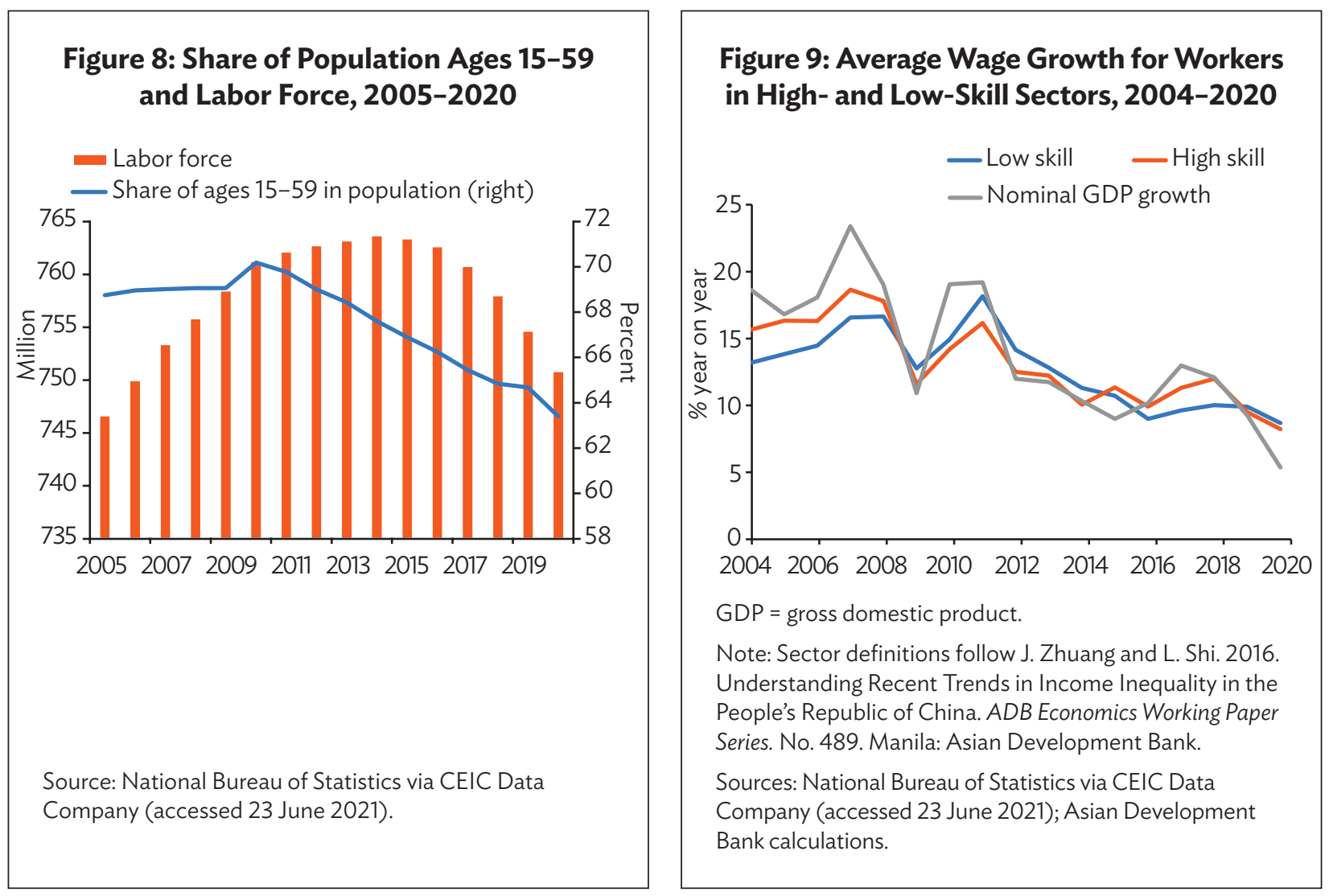

Rozelle et al. (2020) argue that the PRC-after having followed the Lewis model of development in the first 3 decades after starting reforms-reached another turning point when, in the 2010s, rising wage pressure led to some low-wage and labor-intensive production being relocated to other countries, including Viet Nam (electronics) and Bangladesh (textiles). In the mid-2010s, wage growth began to polarize, with skill-intensive services catering to the middle class, such as finance, banking, health, education, and information technology, profiting from this trend. At the same time, this development failed for labor-intensive low-wage services that now absorb labor from manufacturing and construction - two industries that have experienced employment declines since 2013 (Rozelle et al. 2020). This explanation is consistent with wages in high-skill sectors rising faster than in low-skill ones from 2015 until wage growth in both categories declined in 2019 and 2020 as economic growth slowed (Figure 9).

The rural-urban income gap started to narrow after 2007. The growth of urban incomes outpaced rural incomes during the export-led growth until the global financial crisis of 2008-2009, after which rural incomes grew faster than urban ones (Figure 10). The ratio of urban-to-rural incomes improved from its peak at 3.1 in 2007 to 2.6 in 2020 (Figure 11). Increased investment in rural areas, higher productivity growth, and more nonfarm employment in rural areas led to a narrowing in the rural-urban income gap, which nevertheless remains more pronounced in poorer provinces (World Bank 2020). ${ }^{14}$

14 Lower educational attainment continues to limit the income opportunities of rural workers (World Bank 2021). A vitalization of rural areas, especially nonfarm job opportunities, is needed to strengthen rural income (ADB 2021a). 


\section{Figure 10: Growth in Disposable Income Per Capita, 1980-2020}

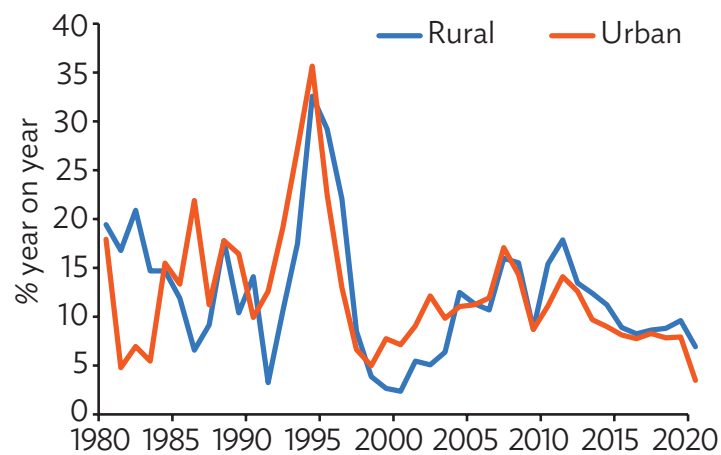

Source: National Bureau of Statistics via CEIC Data Company (accessed 23 June 2021).
Figure 11: Ratio of Urban to Rural Per Capita Disposable Income, 1980-2000



Source: National Bureau of Statistics via CEIC Data Company (accessed 23 June 2021); Asian Development Bank calculations.

Statistics on urban-rural income disparities provide two key insights (Figure 12). First, in rural areas, income from businesses (e.g., selling produce) is higher than in urban areas, but the opposite holds true for net income from property. ${ }^{15}$ Second, net income from transfers is higher in urban areas, which is surprising as one would expect more transfer recipients in rural ones, which tend to be much poorer than urban areas. However, pensions, the country's largest single transfer program, are very unequally distributed, andaccounting on average for more than $10 \%$ of household income-go overwhelmingly to urban retirees, a minority of the population ( $\mathrm{Li}$, Sicular, and Tarp 2018). Consequently, contributory pensions increase the urban-rural gap as rural residents receive considerably lower ones (Lustig and Wang 2020).

Figure 12: Disposable Income of Urban and Rural Residents by Source, 2013 and 2020
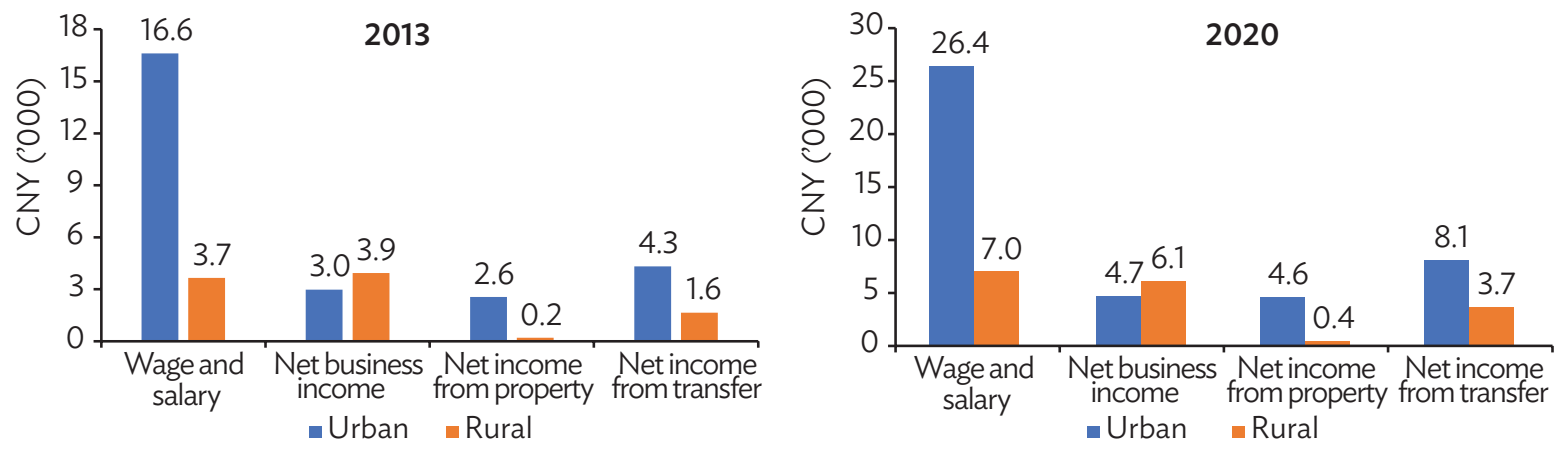

Source: National Bureau of Statistics via CEIC Data Company (accessed 23 June 2021).

\section{Outlook}

While the previous sections discussed the development of inequality in the PRC, identifying factors driving inequality in the future can help in the choice of the right policy responses. Some developments that led to increases in inequality in the past, such as the market-oriented reforms of the 1980s and the export-led economic boom in the first decade of the 2000s following the PRC joining the WTO, are one-off events. But the country's population aging is increasing inequality, which is an emerging

15 Here, property includes several asset classes and not only immovable property. 
challenge (Jain-Chandra et al. 2018; Wang et al. 2017; Chen, Huang, and Li 2017). ${ }^{16}$ Population aging was found to be negatively correlated with the labor share, resulting in higher inequality (Wang et al. 2017). ${ }^{17}$

Another important question is whether wages will diverge and thereby drive up income inequality. Highskilled professionals tend to profit from economies that are more developed. As the PRC's economy matures, workers move from manufacturing to labor-intensive, lower productivity-and hence low-paid-services jobs, as seen in advanced economies (Rozelle et al. 2020; Goodhart and Pradham 2020). ${ }^{18}$ Contrary to earlier expectations that a shrinking labor force could result in shortages of workers that drive up average wages (ADB 2014a), recent empirical evidence presented by Rozelle et al. (2020) show that employees moved from manufacturing to services. This shift adversely affects wage growth because low-skill services absorbing manufacturing workers are more labor-intensive and have lower productivity growth (Goodhart and Pradham 2020). This could help explain the observation mentioned earlier that the PRC's skills premium appears to have increased again in recent years and that this trend is likely to continue. The PRC's 14th Five-Year Plan and the longer-term goal to increase domestic technological innovation favor high-skill labor.

To tackle wage polarization, a well-designed, progressive PIT could mitigate rising wage inequality by redistributing a part of the wage increases of top earners (section III).

Another cause of rising inequality in the future could be income from property-that is, capital and rental income-outpacing wages. From 2013 to 2020, urban wages rose by 58.8\%, while net property income increased by $81.3 \%$ (Figure 12). Because property owners have enjoyed faster income growth than wage earners, capturing nonwage income for taxation purposes has become increasingly important to contain rising inequality (section III).

Results from the latest PRC census in 2020 stoked concerns that the population could age much faster than originally expected (Yu and Mitchell 2021). Although the adverse impact of population aging on the workforce can be delayed by increasing the legal retirement age, as envisaged in the 14th Five-Year Plan, costs for health care, long-term and elderly care, and public pensions will inevitably rise, putting an additional burden on local governments.

\section{Summary}

The analysis in this section found the following:

(i) By international comparison, the PRC has a high Gini coefficient after redistribution, which remains close to the market Gini given the very low level of redistribution.

(ii) Income inequality rose alongside strong growth in the first decade of the 2000s, toward the end of which it peaked. Inequality then retreated slightly in the first half of the 2010s, before edging up in the second half of the decade.

(iii) The distribution of disposable income has not changed much in recent years, with the Gini coefficient staying around 0.47 and the ratio of the highest-to-lowest income quintile staying above 10 .

(iv) The services sector is showing signs of wage polarization.

(v) COVID-19 likely hit lower-income households hardest, increasing inequality. ${ }^{19}$

(vi) From 2013 to 2020, nonwage income in form of income from property outgrew wages.

(vii) Since around 2010, growth in rural income outpaced urban income growth, and the ratio of urban-to-rural disposable income dropped to 2.6 in 2020, down from 3.1 in 2007.

(viii) Demographic aging is a driver of income inequality in the PRC.

16 Urbanization is another established inequality-increasing factor (ADB 2016; Jain-Chandra et al. 2018).

17 Wealth capital is more unequally distributed than income in the PRC. Assuming a close association between being capitalrich and overall income, income inequality rises when the capital share increases. See Milanovic (2016).

18 OECD (2018) summarizes the challenges for inclusive growth in the face of digital transformation.

19 The Gini coefficient for 2020 had not been released at the time of writing. 


\section{Wealth Inequality}

This section discusses wealth Gini estimates for the PRC, compares the share of its top 1\% and 10\% globally, and examines housing price increases as a driver of wealth inequality.

\section{Wealth Gini}

Reliable statistics on the PRC's wealth inequality are difficult to obtain. ${ }^{20}$ Estimates of the wealth Gini coefficient show a high level of wealth inequality in the 2010s, with the coefficient at about 0.70 (Figure 13). The richest $10 \%$ have gradually gained a larger wealth share since 1995 , but this contracted for the bottom 90\% (Figure 14). As noted earlier, income inequality declined somewhat in the first half of the 2010s, a period during which the wealth share of the top 10\% stabilized. This was likely driven by factors other than a moderate improvement in income, ${ }^{21}$ such as restrained increases in real estate prices in that period, which is discussed later in this section.

Figure 13: Wealth Gini Coefficient, 1981-2020

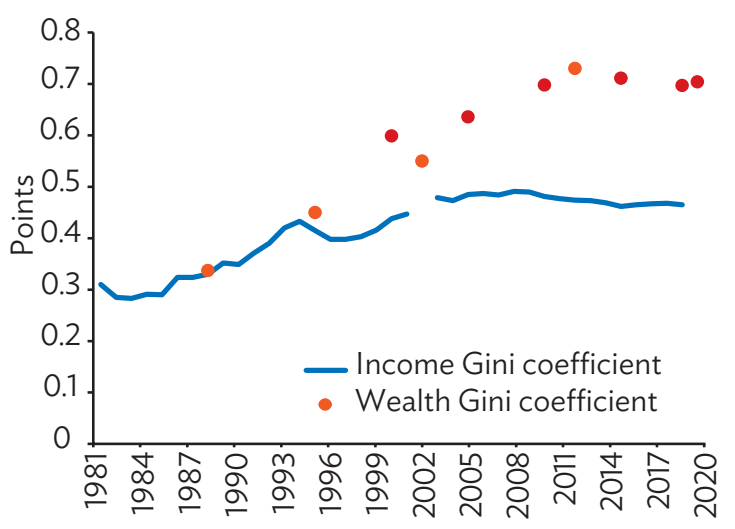

Note: Wealth Gini coefficients for 2000, 2005, 2010, 2015, 2019, and 2020 (in red) from Credit Suisse. 2021. Global Wealth Report 2020. Credit Suisse Research Institute. Other wealth Gini coefficients compiled from different sources (in orange).

Sources: Asian Development Bank. 2016. Reducing Income Inequality in the People's Republic of China. Observations and Suggestions. No. 2. Manila; Credit Suisse (2021); National Bureau of Statistics via CEIC Data Company (accessed 23 June 2021); Economist Intelligence Unit. 2017. Wealth Inequality in China: A Neglected Topic. 29 September; M. Ravallion and S. Chen. 2007. China's (Uneven) Progress against Poverty. Journal of Development Economics. 82 (1). pp. 1-42; Y. Xie and Y. Jin. 2015. Household Wealth in China. China Sociological Review. 47 (3). pp. 203-229.
Figure 14: Wealth Distribution, 1995-2015

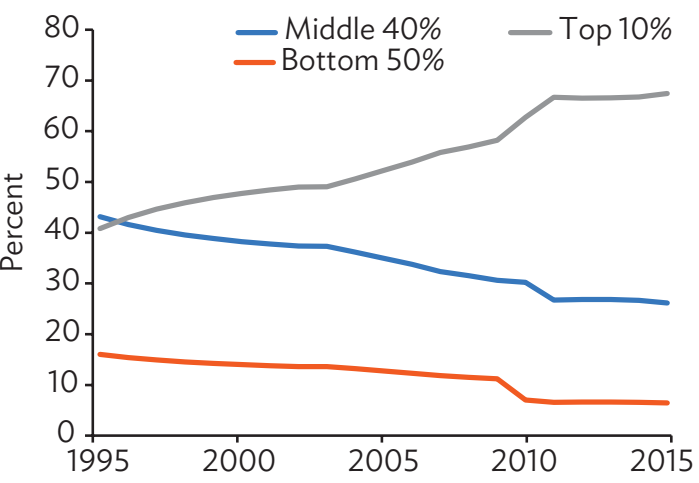

Source: World Inequality Database. https://wid.world/ (accessed 22 June 2021) based on T. Piketty, L. Yang, and G. Zucman. 2019. Capital Accumulation, Private Property and Rising Inequality in China, 1978-2015. American Economic Review. 109 (7). pp. 2469-2496.

20 Besides a lack of wealth-related tax data, household surveys frequently do not capture the wealth of the ultrarich, with corrections resulting in differences in estimates.

21 Xie and Jin (2015) find wealth is weakly correlated with income (using 2012 data), with the correlation being more pronounced for the highest and lowest quartile of wealth distribution than for those in the middle. 


\section{Wealth of the richest $1 \%$ and $10 \%$}

Estimates in Piketty, Yang, and Zucman (2019) indicate the share of the PRC's richest 10\% has risen since 1995, much faster than in the United States and France (Figure 15). ${ }^{22}$ After a steep increase in the first decade of the 2000s, the wealth share of the PRC's richest $10 \%$ seems to have leveled off by the early 2010s. Figure 15 shows strong increases in the PRC's wealthiest $1 \%$ in the first decade of the 2000s, which fits the narrative of the emergence of a "new class of ultra-rich" (Li, Sicular, and Tarp 2018).

\section{Figure 15: Top 10\% and Top 1\% Wealth Share, 1980-2015}
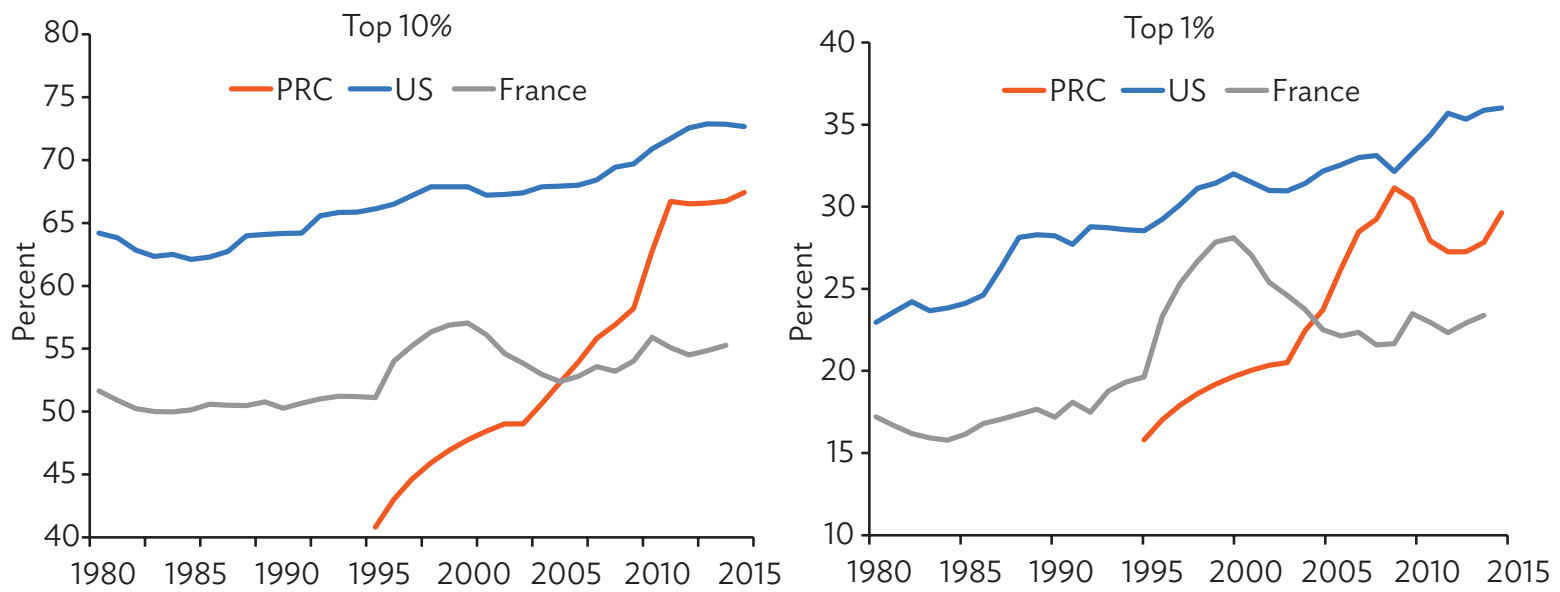

PRC = People's Republic of China, US = United States.

Source: World Inequality Database. https://wid.world/ (accessed 22 June 2021) based on T. Piketty, L. Yang, and G. Zucman. 2019. Capital Accumulation, Private Property and Rising Inequality in China, 1978-2015. American Economic Review. 109 (7). pp. 2469-2496.

Piketty, Yang, and Zucman (2019) estimate the average wealth of the PRC's top 1\% at CNY8.3 million for 2015, with a threshold of nearly CNY3.0 million to join the group. ${ }^{23}$ To get into the top $0.1 \%$, a minimum of CNY8.0 million was needed-and more than a million people qualified, with their average wealth at CNY46.2 million. In 2015, the top $0.1 \%$ held about one-sixth (16.4\%) of the PRC's total wealth share, the top $1 \%$ nearly one-third (29.6\%), and the top $10 \%$ slightly over two-thirds (67.4\%).

\section{Rising real estate prices}

NBS data show house prices in the PRC increased by an annual average of 7.5\% from 2010 and 2020, with price increases most pronounced in first-tier and some second-tier cities in the second half of the 2010s (Figure 16). The price increases made real estate less affordable, resulting in a gap between those who own real estate and those who do not (Zhang, Sun, and Zhang 2020; Li and Fan 2020). Rising housing wealth was the biggest contributing factor to wealth inequality from 2011 to 2017 and the only driver over 2015-2017 (Wan, Wang, and Wu 2021). ${ }^{24}$ This is not surprising given the massive property price increases during that period.

22 Piketty, Yang, and Zucman (2019) do not take into account assets held abroad by wealthy PRC residents.

23 The adult population in 2015 was 1,07 billion in the sample used by Piketty, Yang, and Zucman (2019).

24 Decomposition included financial wealth, housing wealth, productive wealth, land assets, vehicles, durables, and debt. 
Using the available official data ${ }^{25}$ and grouping cities in tiers, it becomes obvious that first-tier citiesBeijing, Guangzhou, Shanghai, and Shenzhen, with a combined population of 83 million-show the biggest housing price increases (Figure 17). The top four cities in the second tier (combined population 36 million) have also shown steep housing price increases in recent years. Prices in all subsets of cities shown in Figure 17 increased by at least 10\% per year over 2010-2019, with the strongest growth in firsttier cities, averaging $12.4 \%$ per year.

\section{Figure 16: Price Increases for Newly Constructed Homes, 2011-2021}

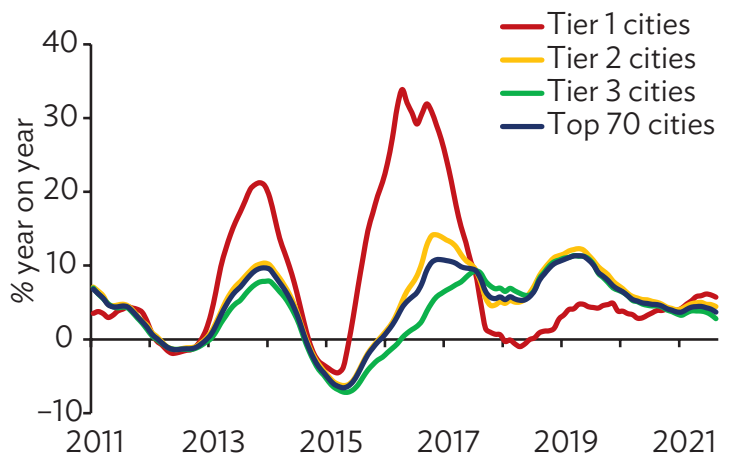

Note: Tier 1 cities are Beijing, Guangzhou, Shanghai, and Shenzhen; tier 2 has 31 provincial capitals and larger municipalities; tier 3 has 35 other cities.

Sources: National Bureau of Statistics via CEIC Data Company (accessed 23 June 2021); Asian Development Bank calculations.

\section{Figure 17: Average Selling Price Increase of Residential Property in Tier 1 and 2 Cities}



Note: Sample comprises 35 cities. Top 4 tier 2 cities are Hangzhou, Nanjing, Ningbo, and Xiamen.

Sources: National Bureau of Statistics via CEIC Data Company (accessed 23 June 2021); Asian Development Bank calculations.

Figure 18 shows the declining affordability of real estate in some cities over 2015-2019. ${ }^{26}$ Indeed, property prices are very high in relation to local disposable income, and buying property in the PRC is less affordable than in OECD countries. ${ }^{27}$ This is especially so in the PRC's first-tier cities, where prices have increased the most and to the extent that they have outgrown gains in disposable income. The younger generation in particular has found itself excluded from the property market despite their generally better education. ${ }^{28}$ As for the effects of rising housing prices on inequality, Wan, Wang, and Wu (2021) find that rising property prices have slightly increased wealth inequality from 2011 to 2017, the latest year covered in their analysis.

25 Real estate price data are sketchy for the PRC. The NBS publishes absolute per square meter prices for selected cities, calculated as an average from transactions. The data do not take into account locations within cities or the age of buildings.

26 The government is trying to stabilize property prices (ADB 2021b; The Economist 2021b). On a wider discussion of the footprint of monetary policy on inequality, see BIS (2021).

27 Housing prices in OECD countries are more affordable, averaging slightly over 10 times the annual income of a couple with two children for a 60-square-meter apartment in selected capitals in 2015 (OECD n.d.) Adjusted for family income and size, affordability in major PRC cities would still be lower than in OECD countries.

28 The real estate market in the PRC was privatized only in the late 1990s. Older generations could often either buy their home at a favorable price or continue to pay moderate rents due to long-standing rent contracts. 
Figure 18: Home Purchase Price-to-Income Ratio in Selected Cities, 2015 and 2019
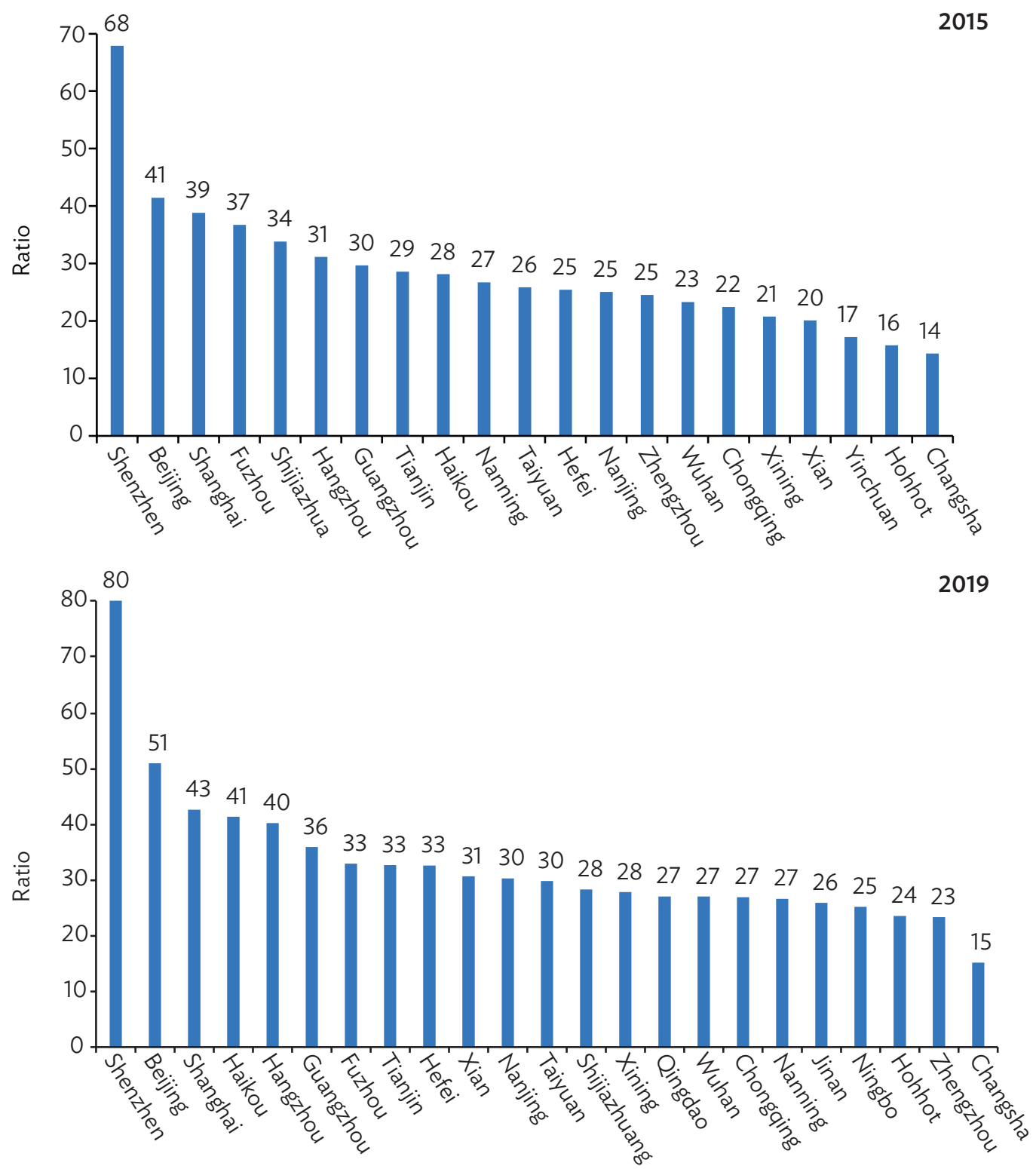

Notes:

1. Selected cities due to limited data availability.

2. Assumed apartment size is 90 square meters.

3. Price-to-income ratio $=\left(\right.$ average price per square meter $\left.^{*} 90\right) /$ annual disposable income per capita.

Sources: Municipal bureaus of statistics and National Bureau of Statistics via CEIC Data Company (accessed 21 June 2021); Asian Development Bank calculations. 


\section{Regional Differences}

The PRC not only faces wide regional economic disparities but also disparities in access to basic public services and social welfare. Since the mid-2000s, some gradual regional convergence has taken place as economic growth in the central and western regions outpaced the wealthier eastern region (Figure 19). ${ }^{29}$ The ratio of the richest three provincial administrations in per capita GRP to the poorest three narrowed from 6.2 in 2000 to 4.7 in 2010 and further to 3.2 in 2019 (Figure 20). ${ }^{30}$
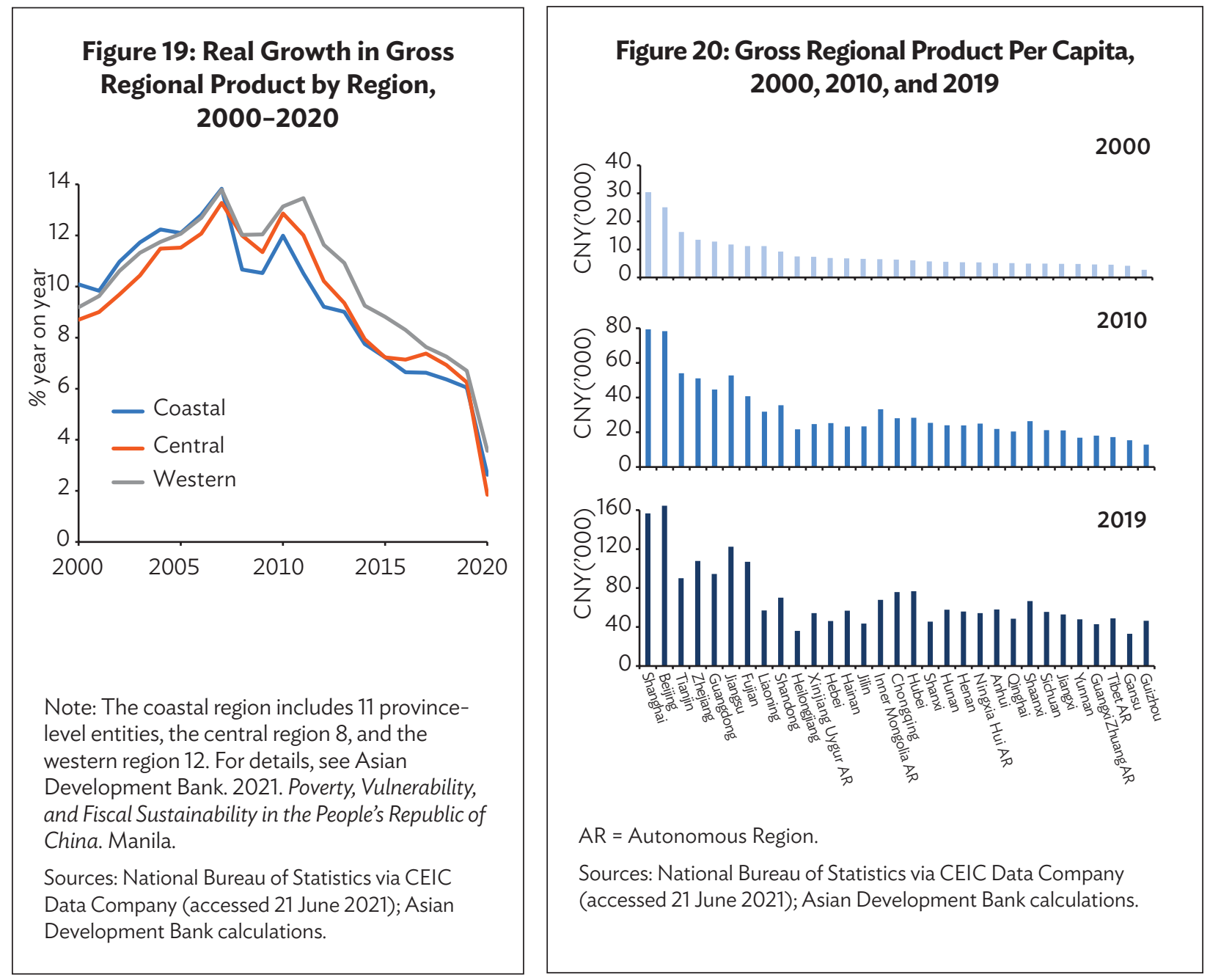

Increased public investment, mostly in infrastructure and transportation, as well as increased social welfare spending, supported the catch-up of lagging regions since the early 2000s (World Bank 2020). However, a further narrowing of regional inequalities will face headwinds from diminishing returns on investment, financial imbalances, and increasing debt that constrain further investment-driven growth (World Bank 2020). Because the government tightened on- and off-budget spending in 2018, growth in infrastructure investment declined sharply and has remained moderate ever since (ADB 2019).

29 For a detailed discussion on regional convergence, see World Bank (2020), which identifies increased investment in lagging regions as the main driver.

30 For inequality, the decline in differences between provinces contributed to the leveling-off in income inequality (JainChandra et al. 2018). 
Sizable regional differences remain in access to basic public services and social security benefits. In general, wealthier local governments have higher per capita expenditure, which affects the delivery of public services (Figure 21). Public health and education services, as well as unemployment support, account for a substantial portion of local government fiscal expenditure-about $38 \%$ in 2019 . Notable differences exist in the spending levels of provinces (Qiao et al. forthcoming). Public health services are better in richer provinces even though poorer ones tend to spend more on health care as a percentage of their GRP (Jin and Qian 2020). Although the national average of hospital beds increased from 2004 to 2014, dispersion across counties increased (Wingender 2018). For education, richer provinces spend per capita more than poorer ones (World Bank 2020).

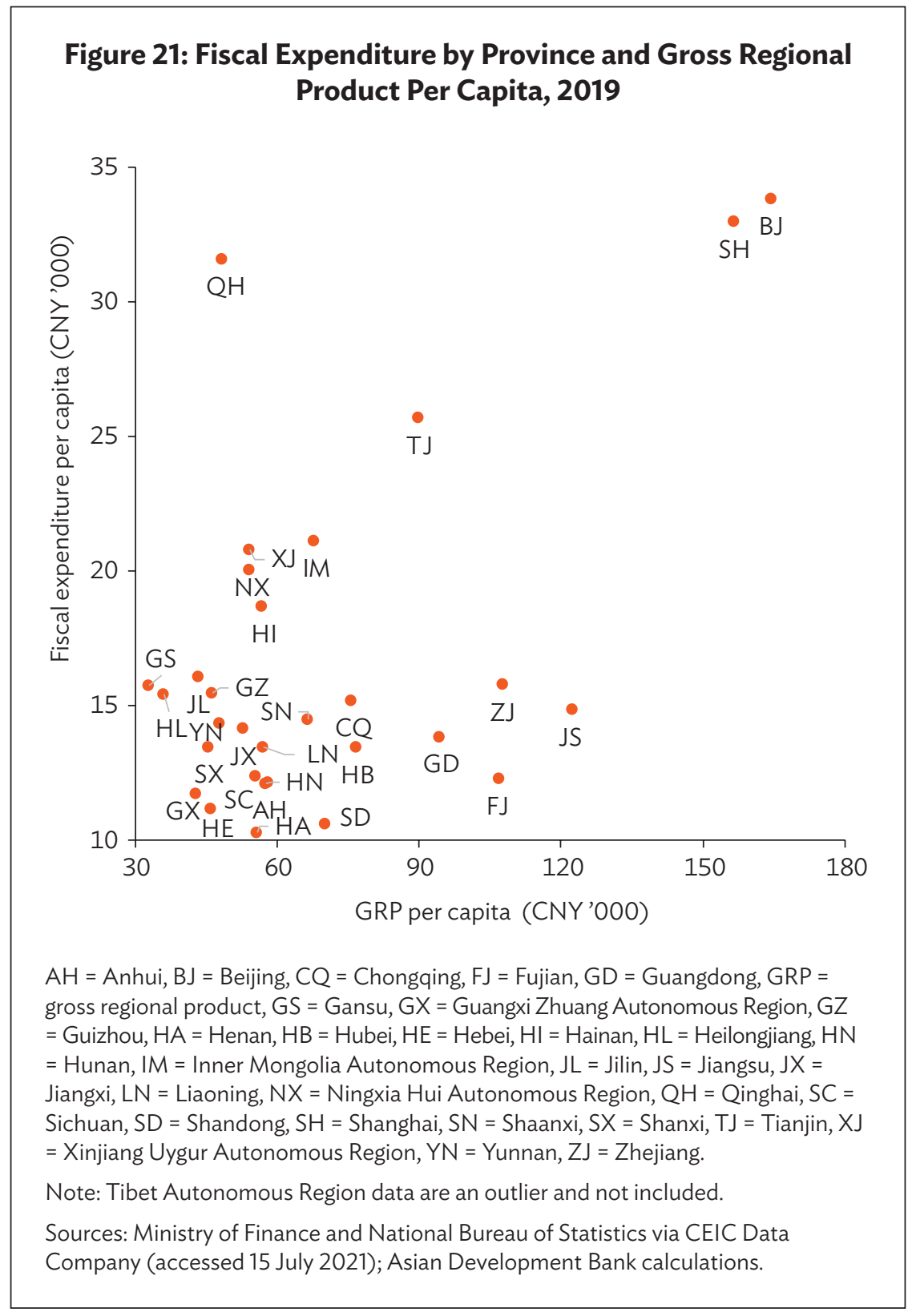

For public pensions, the country's largest single transfer program, the average pension of urban employees differs substantially across provinces. In 2015, Shanghai's was double that in Chongqing (CNY3,644 versus CNY1,816), although their replacement ratios-average benefit divided by a province's average wagewere similar at $40 \%$ and $36 \%$, respectively (Wong 2020). Despite substantial variations in the replacement 
ratio across provinces, ranging 36\%-63\%, the ratio tends to rise with benefits-except in some wealthy coastal provinces that show high absolute benefits, but low replacement ratios (Wong 2020). Reforms to central-local government fiscal relations could help narrow regional disparities (section IV). ${ }^{31}$

\section{E. Reform Needs}

Income inequality after redistribution remains high in the PRC by international comparison because of the low level of redistribution via taxes and public transfers. Although income inequality improved in the first half of the 2010s, it edged up in the second half of the 2010s as income growth in low-skilled sectors was overtaken by income growth in high-skill sectors.

Without policy action, wage polarization and a rising share of income earned from property will likely increase inequality in the future. Recent changes to PIT have led to a situation in which only the richest quintile pays some but not much PIT. So, collection remains low, equal to 1.1\% of GDP in 2019 compared with $8.1 \%$ on average in OECD countries in 2018 (OECD 2020). PIT collection needs to be increased to effectively redistribute income, thereby mitigating income inequality. The current system of withholding taxes from formal wages, while missing out on rapidly increasing nonwage incomes, may even be regressive (Ahmad and van Rijn 2020). ${ }^{32}$ Section III discusses tax reforms that can tackle these issues.

An unequal distribution of wealth has led to the emergence of the ultrarich. Wealth inequality has been high in the PRC for some time, but where this trend is going is hard gauge. The accuracy of wealth inequality estimates is hard to verify, and much of the missing information on wealth inequality and the wealth gap is related to the absence of taxes - inheritance and gift taxes, a nationwide recurrent property tax, and a capital gains tax-that mitigate wealth inequality and, as a side benefit, also provide timely wealth-related information.

Yet, the urban-rural income gap has narrowed for more than a decade and per-capita GRP differences between provinces have also narrowed. That said, basic public services and social security benefits remain unevenly distributed. Fiscal imbalances and mounting debt in many economically weaker provinces make fiscal reforms urgent (section IV).

31 County data are available only until 2009. For an analysis of intra-provincial inequality (until 2009), see Liu, MartinezVelasquez, and Wu (2016).

32 In addition, social security reforms will be needed to tackle the regressivity of social security contributions (IMF 2018). Social security reforms, however, are beyond this paper's scope. For reform suggestions, see ADB (2020a). 


\section{TAX REFORMS TO REDUCE INEQUALITY}

\section{A. Taxes to Reduce Inequality}

Different taxes can be used to tackle different forms of inequality. Income inequality can be addressed by a progressive PIT system, ideally covering all kinds of personal income. Wealth inequality can be tackled by a nationwide recurrent property tax and levying nationwide inheritance and gift taxes to prevent the unequal distribution of wealth being entrenched through generations. A recurrent property tax could capture part of the wealth increase from higher real estate prices and potentially slow housing price increases.

The PRC's current tax structure is still heavily reliant on indirect taxes on goods and services (Figure 22). This contrasts with international experience, suggesting that with increasing income levels, countries move toward direct taxes on income and property (ADB 2020b). In 2019, value-added tax on domestic goods and services alone accounted for $39 \%$ of the PRC's tax revenue, much higher than the combined contribution of all direct taxes (i.e., PIT and corporate income tax). The ratio of direct to indirect taxes was 0.43 in 2019, lower than in other Asian countries and much lower than the average of OECD countries, where it was at 1.62 in 2017 (Qiao et al. forthcoming).

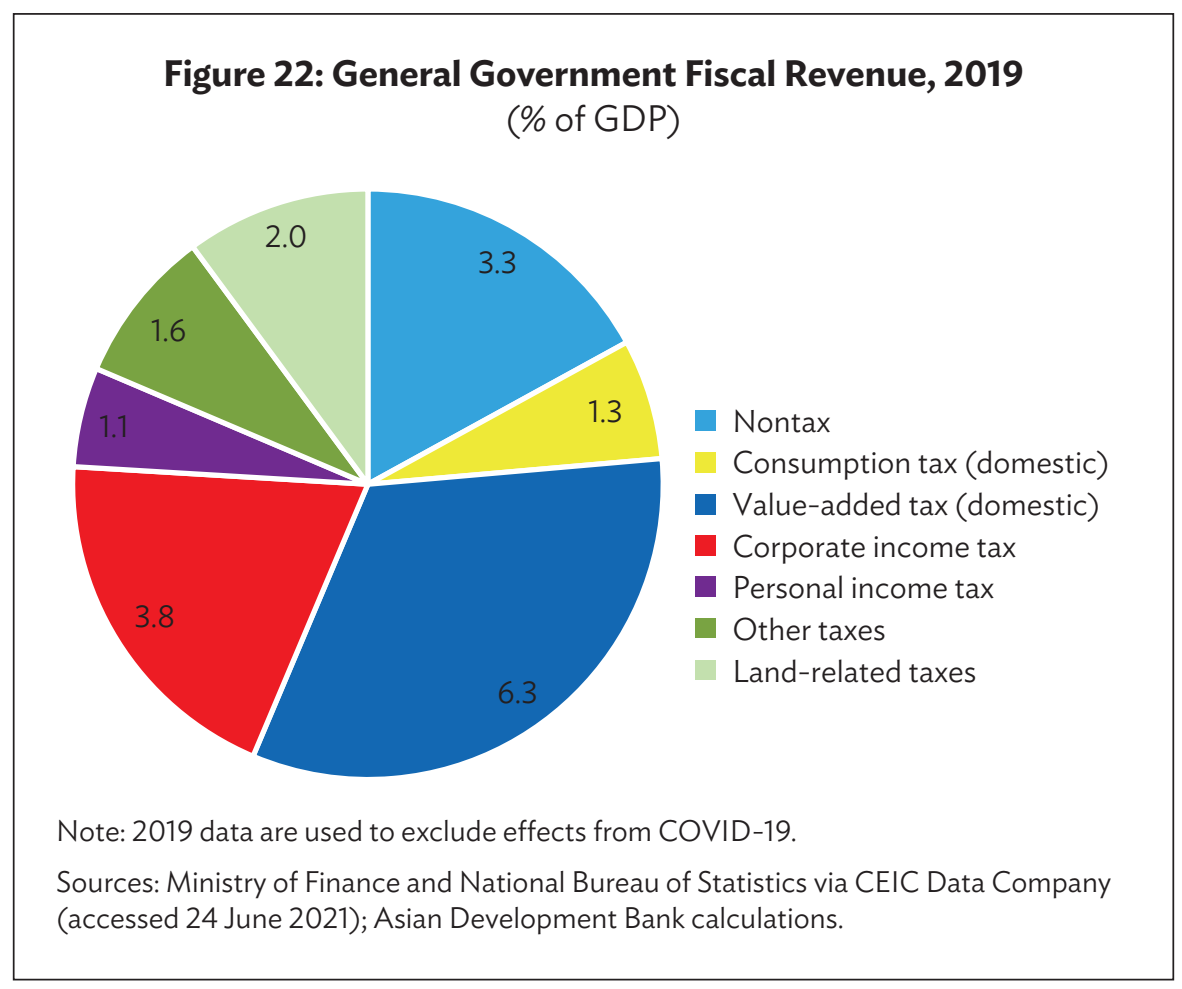

Moreover, PIT reforms in 2018, which brought major changes to the PIT system, moved in an unfavorable direction from an equality standpoint. The share of taxpayers in urban employees is estimated to havefallen from 44\% to 15\% after 2018's Amendment to the Personal Income Tax Law, according to the Ministry of Finance, as reported by Glenn and Qiu (2018). The amendment increased the monthly basic deduction for PIT from CNY3,500 to CNY5,000. It integrated income from wages and salaries, remuneration 
for personal services, and the remuneration and royalties received by authors into "comprehensive income" by aggregating annual income from these categories, which-after deductions-is subject to a progressive tax rate. ${ }^{33}$ Changes also included the introduction of additional special deductions for the education of children, treatment costs for serious illness, elderly care, continuing education, and mortgage interest and rental expenses.

Adjusting tax brackets and increasing the monthly basic deduction to CNY5,000 made PIT less progressive (Figures 23 and 24). Figure 24, which shows average tax rates for monthly gross income, indicates the progression flattened more at the lower end, although it must be kept in mind that a monthly income of CNY20,000, or CNY240,000 per year, is high in the PRC (Figure 6). Before the PIT reforms this income was taxed at a much higher rate. Conversely, although PIT reforms resulted in a lower tax burden, they also caused lower revenue from this tax source. ${ }^{34}$

\section{Figure 23: Marginal Personal Income Tax Rate}

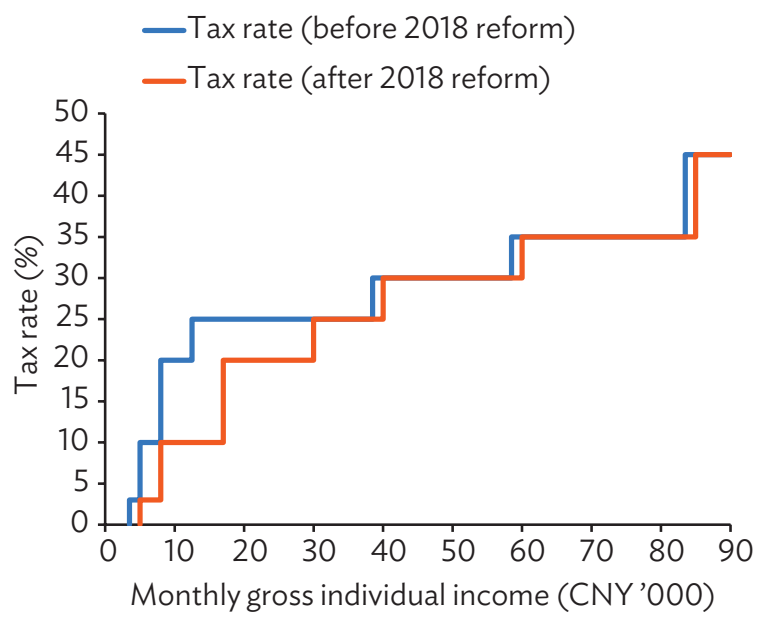

Note: Tax rates take into account the basic deduction, but not special deductions.

Source: State Taxation Administration.

\section{Figure 24: Average Personal Income Tax Rate}

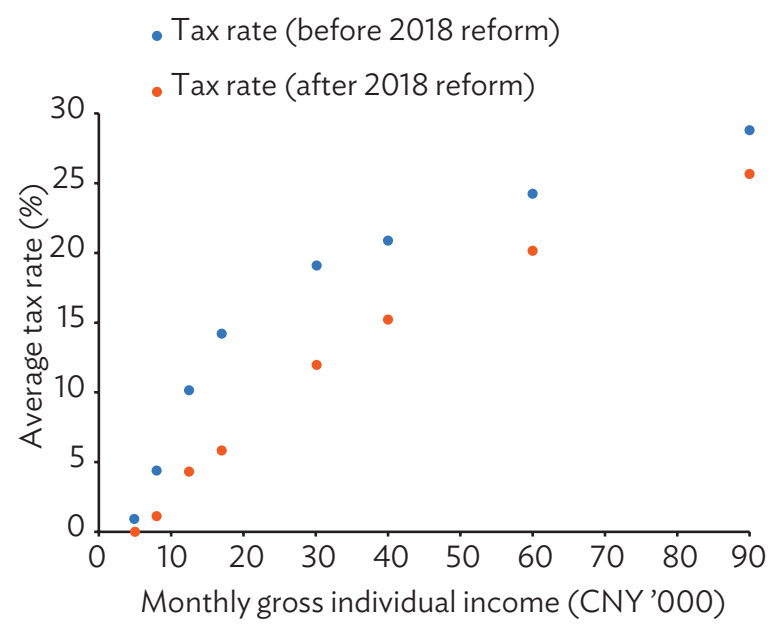

Notes: Selected incomes. Tax rates take into account basic deductions, but not special deductions.

Sources: State Taxation Administration; Asian Development Bank calculations.

PIT contributed little to total tax revenue before the reforms ( $8.3 \%$ of tax revenue, equal to $1.4 \%$ of GDP in 2017) and it fell even further after the reforms, to $6.6 \%$ of tax revenue or $1.1 \%$ of GDP in 2019.35 The OECD average was $23.5 \%$ as a share of tax revenue, including social security contributions, or $8.1 \%$ of GDP in 2018 (OECD 2020). This shows the PRC collects comparatively little PIT.

33 The PRC has coexisting taxation schemes: comprehensive for some income categories after PIT reform and schedular (i.e., applying specific rates for each category) for other types of income.

34 This will further lower the redistribution effect of PIT. OECD (2019) cites an estimate by Li, Zhu, and Zhan (2017) quantifying the redistribution in the Gini coefficient through PIT in the PRC at only 0.25 percentage points (using 2013 data).

35 PIT's share of total tax revenue was $7.5 \%$ in 2020 , but remained at $1.1 \%$ of GDP. The increase in the tax share was mostly due to declining value-added tax revenue in 2020. 


\section{B. Personal Income Tax}

Some areas of PIT could benefit from further reforms when set against international best practice. ${ }^{36}$ The most pressing areas are the tax base, special deductions, the burden on labor income, taxation of capital gains, and tax compliance:

(i) Tax base. This needs to be broadened. As mentioned earlier, the high basic deductions reduce the number of taxpayers, as they fall below the taxation threshold. In 2020, the annual basic deduction of CNY60,000 stood at 1.9 times average disposable income, at CNY32,189 per capita. For widening the tax base, individual business income, pensions, and annuities should be included into comprehensive income, as is done in OECD countries. Uniform progressive tax rates should also be applied-except on the portion of pensions or annuities stemming from contributions made out of previously taxed income, which should be excluded to avoid double taxation (ADB 2020b). A further step could be to integrate capital and rental income by individuals into comprehensive income.

(ii) Special deductions. These should be limited and capped. Adding special deductions to the already high basic deduction would result in a very high level of overall deductions. Furthermore, basic and special deductions partly overlap in scope, which should be avoided. In OECD countries, taxpayers frequently cannot claim both simultaneously. Hence, it is important to delineate the scope of these two types of deductions and streamline them. The lack of caps on applying special allowances enables high-income earners to enjoy substantial tax benefits, undermining the role of PIT in income redistribution. Special deductions are intended to reduce the tax burden for some types of taxpayers, for example, those with many children. Because these deductions frequently aim at smoothing income or redistribution, they should be capped to avoid the possibility of excessive deductions from rising total personal income. Measures should also be taken to verify deductions to avoid tax fraud.

(iii) Burden on labor income. Capital income should be integrated into comprehensive income-a change that would also make PIT more progressive by adding additional income while leaving tax brackets unchanged. Rental income, which is currently also taxed at a flat rate, should be integrated into comprehensive income, moving toward capturing all individual income under the umbrella of comprehensive income and applying a progressive tax rate on the entire amount instead of using different tax schedules.

(iv) Capital income. Capital income, unlike wage income, generally follows a flat tax in the PRC. While the PIT reforms introduced comprehensive income and applied a unified progressive tax rate from $3 \%$ to $45 \%$ to it, capital income is generally taxed at a flat $20 \%$. This dual system - taxing capital and labor income separately-has drawbacks. It weakens the role of PIT in income redistribution, especially since capital income tends to increase with personal income. This system, however, is characterized by a high degree of administrative efficiency because the flat tax on capital income allows final withholding (de Mooij, Lam, and Wingender 2017). To avoid tax evasion, withholding can still be applied to capital income in a system with aggregated income and a unified tax-rate structure, although administration costs would increase somewhat. A solution is to increase the withholding rate and take the individual top marginal tax rate into account later. This would result in a tax credit in case the taxpayer's top marginal rate is below the withholding rate and in an additional tax liability if the top marginal rate exceeds the withholding rate (ADB 2014c).

36 This section draws on ADB (2020b). 
(v) Capital gains. The capital gains of individuals should be taxed. As noted earlier, these are generally not taxed in the PRC except for some real estate transactions. ${ }^{37}$ Coupled with the absence of inheritance and gift taxes, this leads to uncorrected wealth accumulation and inequality. Capital gains should be treated as part of personal income, thus subjected to progressive taxation. And again, withholding a part of realized capital gains at the source will strengthen tax compliance.

(vi) Tax compliance. PIT-collection compliance should be strengthened as tax compliance in the PRC is generally low. Besides weak legal and institutional tax enforcement, reasons for low compliance include the lack of a unified and national taxpayer database, which limits information sharing and matching and targeted tax auditing. To tackle these shortcomings, the enforcement of tax laws must be improved to strengthen compliance. Specifically, it would be helpful for increasing individual compliance to set up a unified national taxpayer database with a two-way declaration system among taxpayers, withholding agents, and tax authorities.

In sum, the PRC's individual income taxation system could be developed further to combine more sources of income into a taxable aggregate, thereby mitigating the system's current low degree of progressivity due to different tax schedules. Other possible options to increase PIT revenue, such as reducing the basic deduction, increasing tax rates, and narrowing the brackets so that higher rates start earlier, should only be considered after the reforms outlined under (i)-(vi) have been implemented. ${ }^{38}$ Table 1 summarizes the recommendations.

Table 1: Recommended Further Personal Income Tax Reforms

\begin{tabular}{lll}
\hline Challenge & & \multicolumn{1}{c}{ Proposed Reform Steps } \\
\hline Weak tax base & - Include individual business income, pensions, and annuities into comprehensive income \\
& - & Tax capital gains as part of personal income \\
\hline Low progressivity & - & Serge more income categories into comprehensive income \\
& - Subject income taxed at a flat rate (e.g., capital income) to progressive rates \\
\hline Low tax compliance & - Withhold taxes, at least in part, at source where possible \\
\hline
\end{tabular}

Source: Author.

\section{Recurrent Property Tax}

The PRC has no nationwide recurrent property tax, but rather five property-related taxes: real estate tax, urban land-use tax, land appreciation tax, cultivated land occupation tax, and deed tax. Revenue from all five types combined totaled $2.0 \%$ of GDP and contributed to $25 \%$ of local government tax revenue in 2019. Because the tax structure focuses on transactions, underreporting these amounts is an issue (ADB 2014c).

A property tax is usually imposed on owners of immovable property based on the value of the property. Property taxation is common throughout the globe due to its many advantages, such as being a steady

37 Gains from the sale of property are taxed at 20\%, with exemptions frequently applicable to individuals selling their homes.

38 The top PIT rate is the highest among all PRC tax schedules and relatively high by international comparison (IMF 2018). Reducing the basic deduction or narrowing the tax brackets would, at least in part, unravel recent PIT reforms. 
source of local government revenue. Property taxation was piloted in Chongqing and Shanghai in 2011, and restricted to high-value properties. There are several exemptions to this tax, which only covers a small part of the housing market and therefore raises little tax revenue (ADB 2014c). In October 2021, the Standing Committee of the National People's Congress authorized the State Council to expand pilot schemes for a property tax in some regions, with the State Council determining the locations to be involved and other details (Xinhua 2021).

Property taxation is used in many countries because it has advantages, such as revenue stability and predictability as property taxes are less affected by downturns in the business cycle and, when properly enforced, difficult to circumvent. Property taxes tend to be progressive since property wealth usually tends to increase with income, and recurrent property taxes have been found to be least distortive to longterm growth (Norregaard 2013). Recurrent property taxes also help to strengthen local government fiscal revenue. This aspect is particularly important for the PRC, where local governments face substantial funding gaps. A local property tax could provide an efficient and sustainable way to help ensure the provisioning of public goods at the local level-and it could help dampen house-price increases (OECD and KIPF 2016).

A property tax in the PRC could be gradually rolled out, starting with a subset of properties or regions. The taxation base could then be broadened by including more units or regions. The following steps would be needed to introduce a property tax: delegation of taxation responsibilities to local governments, defining a nationally standardized tax base and the range of the tax rate, and enhancing local government capacity to administer the tax (ADB 2014c).

The following international best practices are relevant to the PRC:

(i) Tax assignment. Property taxation is typically assigned to local governments since they are closest to the residents on which the tax burden is imposed and who profit from the services financed by the tax. Local governments are also usually in a better position to assess the size or value of a property in their jurisdiction. Most countries choose a form of a differentiated property tax when levying recurrent property taxes; this requires defining an appropriate base and valuation method to avoid the regressivity of a flat tax (Norregaard 2013).

In the PRC, local governments need to have the authority to collect and enforce property taxes in their jurisdictions that follows clear principles and includes limits on taxation. Internationally, rates usually vary from $0.1 \%$ to $1.0 \%$ of the property value, depending on the property type, while the revenue potential of property taxes can reach $2 \%-3 \%$ of GDP, with the average being about $1 \%$ (de Mooij, Lam, and Wingender 2017). Whether local governments should be granted the autonomy to decide on the tax rate within limits set by the central government is debatable. This might lead to poorer cities and regions taxing the highest because they urgently need the additional revenue, and richer ones not availing of the full scope..$^{39}$ That said, the absolute amount of property tax payable would be higher in expensive cities than in low-tier cities under a valuation system that proxies market value. A differentiated tax-free basic allowance depending on the city or region could account for that (de Mooij, Lam, and Wingender 2017).

(ii) Tax base and rate. The definition of a nationally standardized tax base and the range of tax rates is the technically most complex part of levying a property tax. It requires a proper valuation method, an understanding of the tax base, and an adequate choice of tax

39 This possibility is real. A similar situation happened for social security contributions. Poorer provinces frequently collected higher percentages of salaries and wages than richer ones until the central government capped contributions in 2019 to reduce regional differences (ADB 2019). 
rate. A broad tax base enables local governments to set a modest tax rate and still receive significant revenue. Hence, the tax should ideally cover all properties, and exemptions should be kept at a minimum. Local governments should provide support to property owners who have affordability issues, typically those at the lowest income level (ADB 2014c).

For valuing a property, the three most common methods are capital valuation (property tax based on the assessed property value), rental value valuation (tax assessed on the potential rent in an open rental market), and area-based valuation with the tax base being the area and size of the property, taking location or use into account or not. Capital valuation, the preferred method in many countries, has proven complex in volatile markets because valuation is backward-looking, administration-intensive, and requires a constant flow of input data. In practice, valuation for taxation purpose frequently ends up below market prices (Norregaard 2013).

The PRC's rental market is comparatively small, reflecting the preference for home ownership. This might make rental valuation for taxation purposes difficult, as could the fact that there are many subsidized rental schemes, especially for civil servants and employees of state-owned enterprises. Capital valuation might be a preferred option in theory, but it would be complicated by high annual valuation gains in some cities and areas that would require either constant updating or choosing a tax base below market that would undermine the equity principle. As long as proper valuations are not available-and it will take time for them to become available given the size of the housing market-an area-based valuation system could be used. Parameters could comprise the size, location, use (residential or commercial, with possible exemptions for agricultural buildings), and, potentially, the age of a building. ${ }^{40}$ Many emerging market economies use such area- and proxy-based systems (de Mooij, Lam, and Wingender 2017). Because these factors tend to be stable over time, they can be combined with price indexes to determine the annual property tax liability. An area-based valuation system should be flexible enough to be rolled out nationwide in the absence of a complete capital valuation system.

(iii) Government capacity. Government capacity is essential for successfully implementing property taxes. Good-quality property data in particular are needed to ensure completeness, consistency, and fairness to determine property values for taxation. This could be achieved, at least partly, by relying on commercial transaction data and by separating appraisal and tax collection authorities. For valuing property, difficulties persist for assessing market value in the PRC, especially for the subsidized housing of government and state-owned enterprise employees. Property appraisal also continues to be largely done by subsidiary companies of local governments, which have vested interests (ADB 2014c).

Local government capacity and the property registry need to be improved so that property can be valued for taxation purposes. To this end, a consistent valuation system must be created, probably with central government support, and appraisers trained to run the system (ADB 2014c). In the meantime, an area-based valuation system could be a suitable solution.

A nationwide recurrent property tax would both boost local government revenue and help keep rising property prices in check. While many technical details of a recurrent property tax must be evaluated, the most difficult part in practice will be to strengthen the capacity of local governments to properly administer a recurrent property tax. Once operational for property taxation, the nationwide real estate

40 The age of a building can help proxy property value in areas where newer buildings of higher value have been added. The need for such an additional, differentiating parameter also depends on how granular location is defined. 
registry could also be used for inheritance and gift taxation. A nationwide rollout of a recurrent property tax could be done fairly quickly using an area-based method proxying property value. Estimates of the revenue potential differ slightly: 1.0\% of GDP (Bahl, Goh, and Qiao 2014; ADB 2014c) to 1.0\%-1.5\% of GDP (Lam and Wingender 2015). Table 2 summarizes the recommended steps for a recurrent property tax.

Table 2: Summary of Recommended Steps for a Recurrent Property Tax

\begin{tabular}{ll}
\hline Challenge & \multicolumn{1}{c}{ Proposed Steps } \\
\hline $\begin{array}{l}\text { No legal basis for local government } \\
\text { to levy property tax }\end{array}$ & $\begin{array}{l}\text { Delegate specific taxation powers and responsibilities to local governments, with } \\
\text { limits set by central governments }\end{array}$ \\
\hline $\begin{array}{l}\text { Lack of a nationally standardized } \\
\text { tax base and tax rates }\end{array}$ & $\begin{array}{l}\text { Define a nationally standardized tax base, using an area-based valuation system } \\
\text { based on size, location, use (residential/commercial), and age of building }\end{array}$ \\
\hline Weak local government & $\begin{array}{l}\text { Set the tax rate, starting with a moderate unified rate, with few exemptions } \\
\text { tax administration capacity }\end{array}$ \\
\hline
\end{tabular}

Source: Author.

\section{Inheritance and Gift Taxes}

Levying inheritance tax in the PRC would be in line with the OECD's recent call for strengthening inheritance and gift taxation in its member countries to tackle increased wealth inequality. Nine OECD countries have abolished inheritance or estate taxes since the early 1970 s and 24 still levy them, mostly recipient-based inheritance taxes. ${ }^{41}$ Other OECD countries follow different approaches for inheritance, estate, and gift taxes, but these are usually set by central governments (OECD 2021a).

The design of inheritance, estate, and gift taxes varies widely across OECD countries, with significant differences in the levels of wealth that can be passed on free of tax. Despite varying practices, tax exemption thresholds usually favor close relatives. While most OECD countries have progressive tax rates, others apply flat rates. Other than that, tax rates differ widely (OECD 2021a).

Numerous provisions have narrowed inheritance tax bases, reducing potential revenue, efficiency, and fairness, so that only $0.5 \%$ of total tax revenue is sourced from these taxes across the OECD countries that levy them. The share in total tax revenue is the highest in Belgium, Japan, France, and the Republic of Korea, ranging between $1.3 \%-1.6 \%$ (OECD 2021a).

In the PRC, inheritance tax should focus on the rich-specifically, the wealthiest top $1 \%$ or so. ${ }^{42}$ Progressive tax rates should also be applied. While aiming only at the top $1 \%$ may not seem broad enough, one needs to keep in mind that this percentage includes more than 10 million people, all of them dollar millionaires.

41 Inheritance taxes are recipient-based, while estate taxes are charged against the estate. Gift taxes are levied on transactions gratuitously transferring property among persons who are living at the time of the transfer. Gift taxes limit the possibility to circumvent inheritance taxes.

42 OECD (2021a) compiled data on the share of estate subject to inheritance tax. Nationwide data are available only for a few countries. In Germany, Italy, Japan, the United Kingdom, and the United States this share is below 10\%, with the United States at the very low end (0.2\%) and Germany leaning toward the upper end. For the PRC, targeting at most the top 5\% of wealth is therefore recommended, and possibly even the top $1 \%$ only. 
Obvious challenges emerge when looking at levying these taxes from the perspective of real estate wealth. Housing prices in the PRC's big cities often reach seven-figure US dollar amounts for apartments. Exempting these properties from tax so that family homes can be passed on largely tax-free means foregoing tax revenue, but not doing this will result in hefty inheritance tax bills for family homes in major cities, even for middle-class families. The drawback in trying to avoid this by undervaluing real estate for inheritance tax purposes is that this would simultaneously increase the attractiveness of investing in real estate, which runs against government efforts to stabilize housing prices in big cities. Furthermore, property valuation for inheritance tax should be in line with the valuation used for the recurrent property tax.

The issues just highlighted on real estate taxation are examples of the complexity of designing an equitable inheritance tax. In the end, there might be a stronger case for targeting high wealth with an inheritance tax and ensuring proper compliance. Differentiated inheritance and gift tax free amounts for close relatives should reflect this.

Evidence from OECD countries on the revenue potential of inheritance and gift taxes shows that the contribution of property taxes-inheritance, estate, and gift taxes; recurrent taxes on immovable property and net wealth; and taxes on financial and capital transactions in the OECD classification ${ }^{43}$ - to government funding is limited overall. Property taxes averaged 1.9\% of GDP in OECD countries in 2018, with France and the United Kingdom having the highest (4.1\% of GDP each), followed by Canada (3.9\% of GDP) (OECD 2020).

While levying taxes on wealth using a recurrent property tax, coupled with inheritance and gift taxes, would yield additional tax revenue in the PRC, the actual amount would mainly depend on the rate of these taxes and their scope, especially in case of a recurrent property tax. If these taxes were levied without many exemptions, they would cover the vast majority of population, as over $85 \%$ of households own their home (de Mooij, Lam, and Wingender 2017). ${ }^{44}$ But the revenue from inheritance and gift taxes would likely be limited, reflecting the findings just discussed from OECD countries.

International comparisons show that even the OECD countries with the highest proportion of property tax in total taxes rely much more on PIT for revenue than on wealth taxes. From 1965 to 2018, the share of taxes on property fell from $7.9 \%$ to $5.6 \%$ of total tax revenue (including social security contributions) across OECD countries, with Canada, the Republic of Korea, the United Kingdom, and the United States, among others, having property tax revenue exceeding $10 \%$ of total tax revenue. This is still far less than their revenue from PIT, which accounted for $36.2 \%$ of tax revenue in Canada, $18.4 \%$ in the Republic of Korea, 27.3\% in the United Kingdom, and 41.1\% the United States in 2018 (OECD 2020).

To address unchecked wealth accumulation and concentration, inheritance and gift taxes should be levied in the PRC; these taxes should target very high wealth using progressive rates. Table 3 summarizes the recommended steps for this.

43 Capital gains of individuals are part of personal income.

44 Estimating the revenue potential of a property tax is fraught with challenges, because no consistent property valuation exists in the PRC and nationwide property price data are not publicly available. 
Table 3: Recommendations on Inheritance and Gift Taxes

\begin{tabular}{|c|c|}
\hline Challenge & Recommendations \\
\hline Income is taxed, wealth is not & - Levy inheritance and gift taxes, and roll out a recurrent property tax nationwide \\
\hline $\begin{array}{l}\text { Unchecked wealth accumulation } \\
\text { and concentration }\end{array}$ & $\begin{array}{l}\text { - Introduce inheritance and gift taxes at progressive rates beyond specific tax-free } \\
\text { amounts for close relatives } \\
\text { - Levy property taxes according to the (proxied) property value }\end{array}$ \\
\hline $\begin{array}{l}\text { Low overall tax revenue from } \\
\text { individual taxes }\end{array}$ & $\begin{array}{l}\text { - Levy wealth-related taxes, while concurrently increasing personal income tax } \\
\text { revenue }\end{array}$ \\
\hline
\end{tabular}

Source: Author. 


\section{REFORMING INTERGOVERNMENTAL FISCAL RELATIONS}

\section{A. A Bird's-Eye View of Fiscal Arrangements}

Intergovernmental fiscal relations in the PRC have been frequently subject to change. In 1994, a comprehensive fiscal reform led to the redistribution of fiscal revenue from local to central government, while the bulk of fiscal responsibilities stayed with local governments (Figure 25). A formal intergovernmental fiscal transfer system was established to potentially ameliorate regional fiscal disparities (Liu, Martinez-Vazquez, and Qiao 2014).

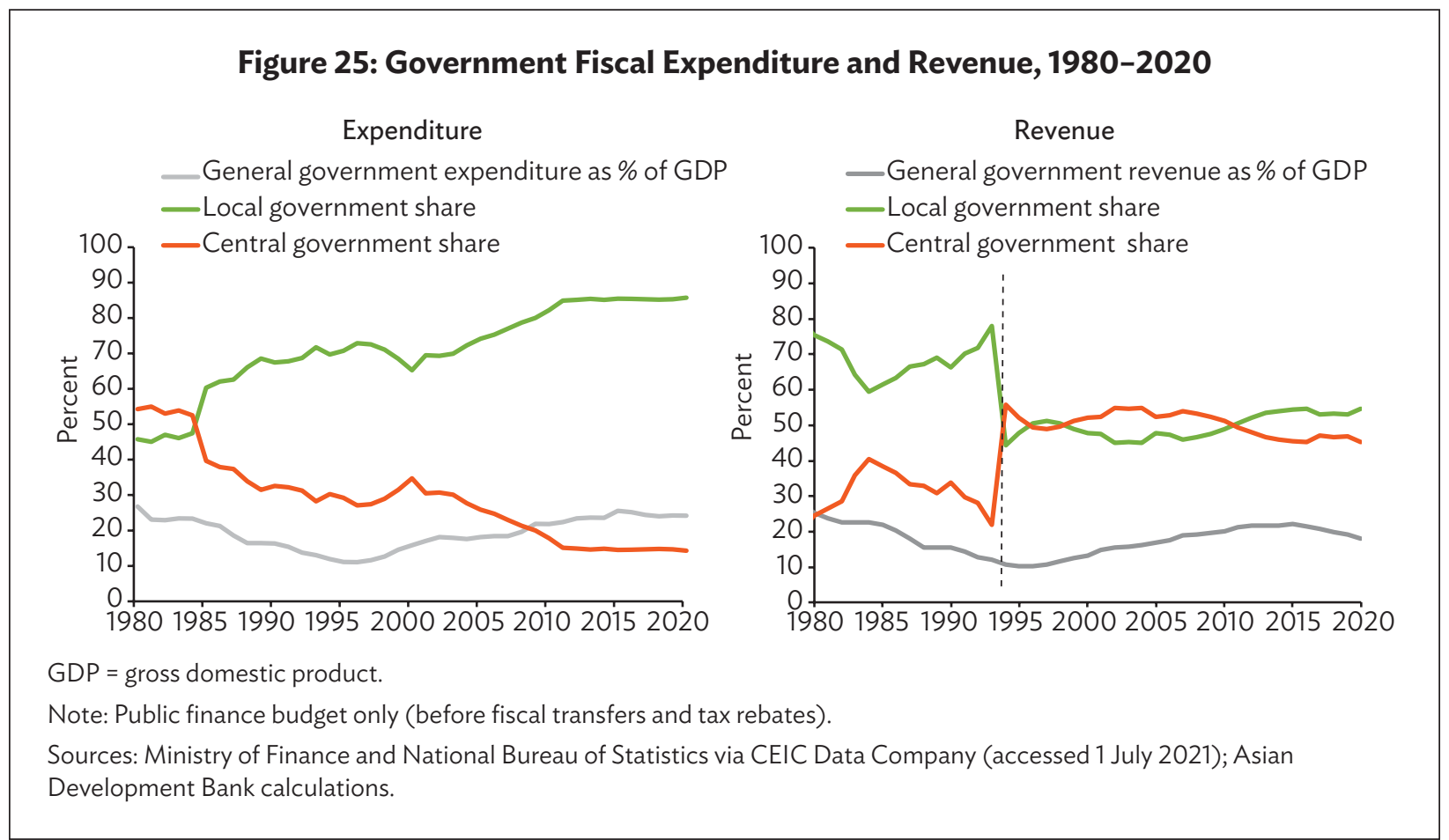

Fiscal expenditure as a share in GDP increased after 1994's fiscal reforms. Local government accounts for about $85 \%$ of total government fiscal expenditure as they provide almost all basic public services and administer social security (Figure 25). Local government fiscal expenditure is the highest in the PRC among all comparators in OECD and UCLG (2019).

Yet, fiscal revenue as share of GDP has been declining (Figure 26). It averaged 19.9\% of GDP during 20162020 , down from $21.8 \%$ during $2011-2015$, as tax revenue declined from $18.5 \%$ of GDP to $16.6 \%$ in the period. Sizable cuts in value-added taxes (VAT) plus shortfalls during the COVID-19 pandemic and, to a lesser extent, PIT reforms contributed to the decline in tax revenue. As a result, local government fiscal expenditure has increasingly exceeded fiscal revenue. In 2019, the vertical fiscal gap, ${ }^{45}$ proxied by local government fiscal expenditure (20.7\% of GDP) minus fiscal revenue (10.2\% of GDP), was $10.4 \%$ of GDP (Figure 27). This shows that local government fiscal revenue is insufficient for the level of expenditure.

45 The vertical gap can be proxied by fiscal expenditure not covered by own revenue (Qiao et al. forthcoming). In 2020, the gap was even wider at the equivalent of $10.9 \%$ of GDP given revenue shortfalls due to COVID-19. 

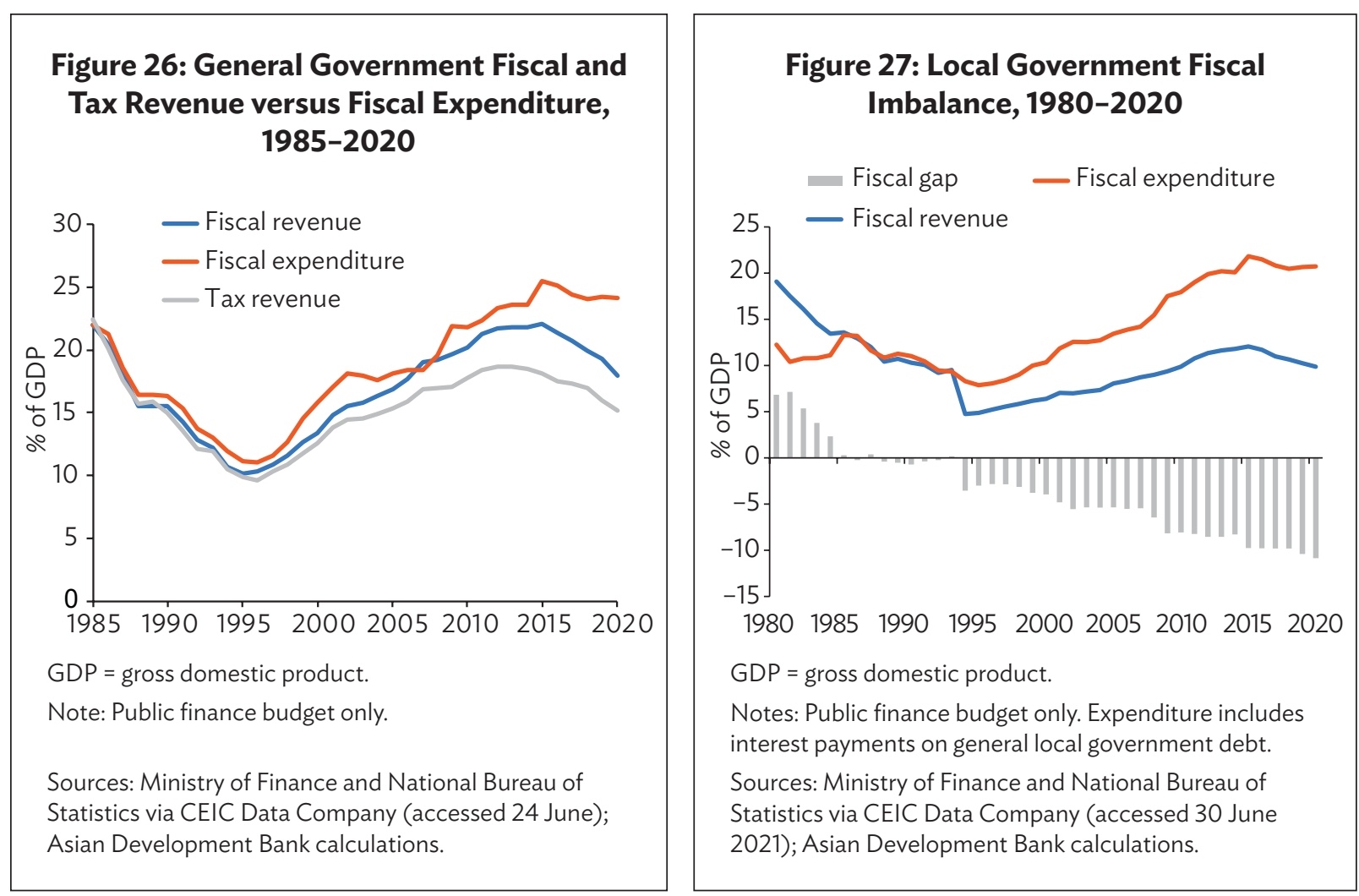

Higher fiscal transfers would be beneficial for narrowing regional disparities, but the big question here is how to finance additional transfers. This is not only a question of how much additional funds local governments need but also how much more the central government can provide on a sustainable basis. And here the picture is not a favorable one: the fiscal balances of local governments have gradually deteriorated, while the central government's fiscal surplus peaked in 2011 (Figure 28).

\section{Figure 28: Central and Local Government Fiscal Balance before Transfers, 1980-2020}

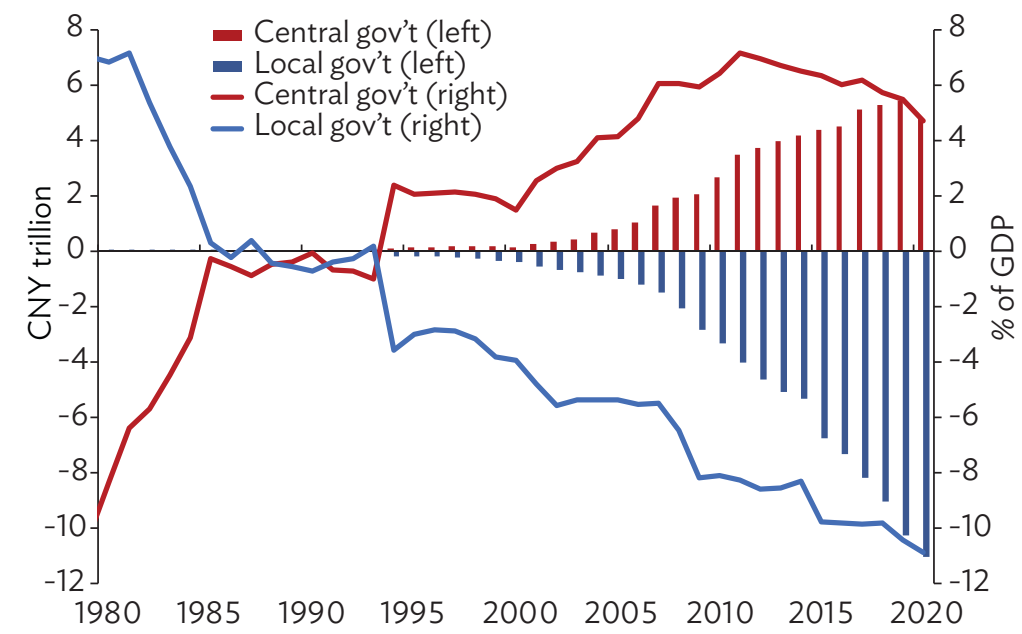

GDP = gross domestic product.

Notes: Public finance budget only. Fiscal balance is fiscal revenue minus fiscal expenditure (before transfers and tax rebates).

Sources: Ministry of Finance and National Bureau of Statistics via CEIC Data Company (accessed 1 July 2021); Asian Development Bank calculations. 
Because local governments are neither allowed to levy taxes ${ }^{46}$ on their own nor issue debt without approval by the central government, they depend on fiscal transfers from the central government. ${ }^{47}$ But these as percentage of GDP have been stagnating for some time (Figure 29). As a result, the fiscal balances of local governments after transfers from the central government have been negative for all provinces except for the Tibet Autonomous Region (Figure 30).

\section{Figure 29: Central Government Fiscal Transfers to Local Governments, 1990-2020}

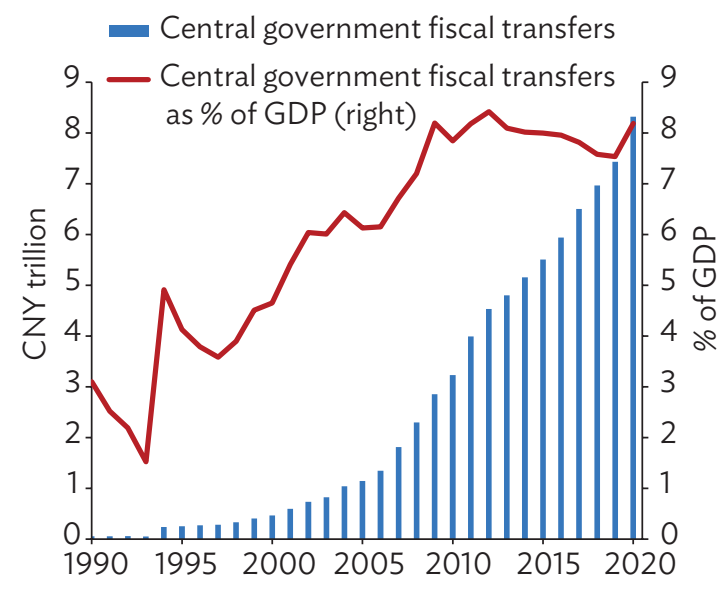

GDP = gross domestic product.

Notes: Includes only public finance budget. Transfers comprise special and general transfers, and tax rebates.

Sources: Ministry of Finance and National Bureau of Statistics via CEIC Data Company (accessed 1 July 2021); Asian Development Bank calculations.
Figure 30: Local Government Fiscal Balances after Transfers, 2019

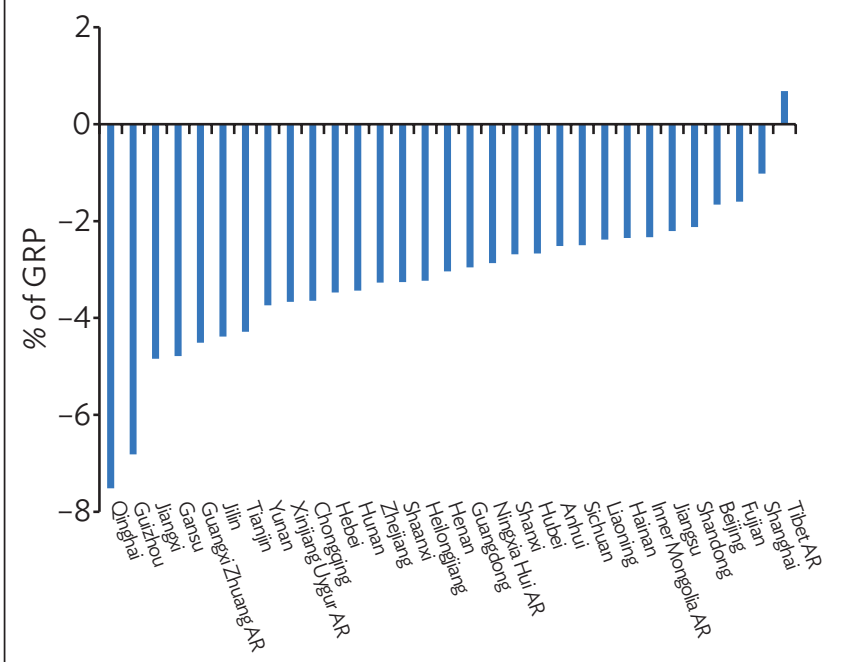

$\mathrm{AR}=$ Autonomous Region, $\mathrm{GRP}$ = gross regional product.

Note: Difference between fiscal revenue and expenditure in the public finance budget, plus fiscal transfers (including tax rebates).

Sources: Ministry of Finance and National Bureau of Statistics via CEIC Data Company (accessed 13 September 2021); Asian Development Bank calculations.

The fiscal gap at the level of local government has two major implications: the unequal provision of basic public services and rising local government debt. Although the main elements of 1994's fiscal reforms are still in place, the revised Budget Law that came into effect in 2015 allowed local governments to issue their own debt-general debt and, for project-financing, special debt-within limits set by the central government. ${ }^{48}$ As a result, government debt rose and accrued at the provincial level (Figures 31 and 32). ${ }^{49}$

Overall, outstanding official government debt-central government debt, and local government general and special debt-rose to $45.8 \%$ of GDP at the end of 2020; most of this (25.3 percentage points) was local government debt (Figure 31). However, debt distribution between provinces is uneven, with some of the richest ones having the lowest debt-to-GRP ratios and many poorer ones showing high ratios (Figure 32).

46 The choice of the selection of tax rates of the urban land-use tax, the environmental protection tax, and the resource tax within legislated limits is the only element of subnational tax autonomy (Qiao et al. forthcoming).

47 No institutionalized transfer system exists for horizontal transfers at the provincial level in the PRC.

48 The Budget Law was revised mainly to bring onto the balance sheet infrastructure-investment financing by local governments, hitherto off-budget. Since 2015, the PRC has used four budgets. The public finance budget covers fiscal expenditure and revenue and the government-managed funds budget funds major investment projects. The other budgets are the state capital operations budget and the social security budget.

49 While this paper focuses on the public finance budget, local government special bond issuance leads to increases in public debt that can adversely affect debt sustainability. 
Figure 31: Government Debt, 2006-2020

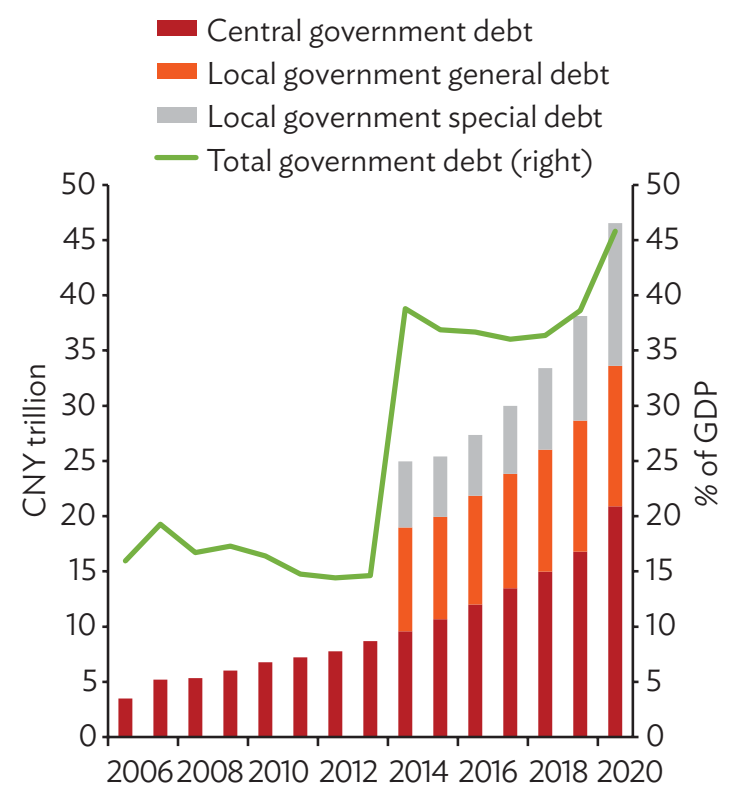

GDP = gross domestic product.

Notes:

1. Official government debt only.

2. The Budget Law was revised effective 2015.

3. In 2014, local government debt was consolidated, and local governments were allowed to issue bonds with central government permission.

Sources: Ministry of Finance and National Bureau of Statistics via CEIC Data Company (accessed 1 July 2021); Asian Development Bank calculations.

\section{Figure 32: Outstanding Local Government Debt by Province, 2019}

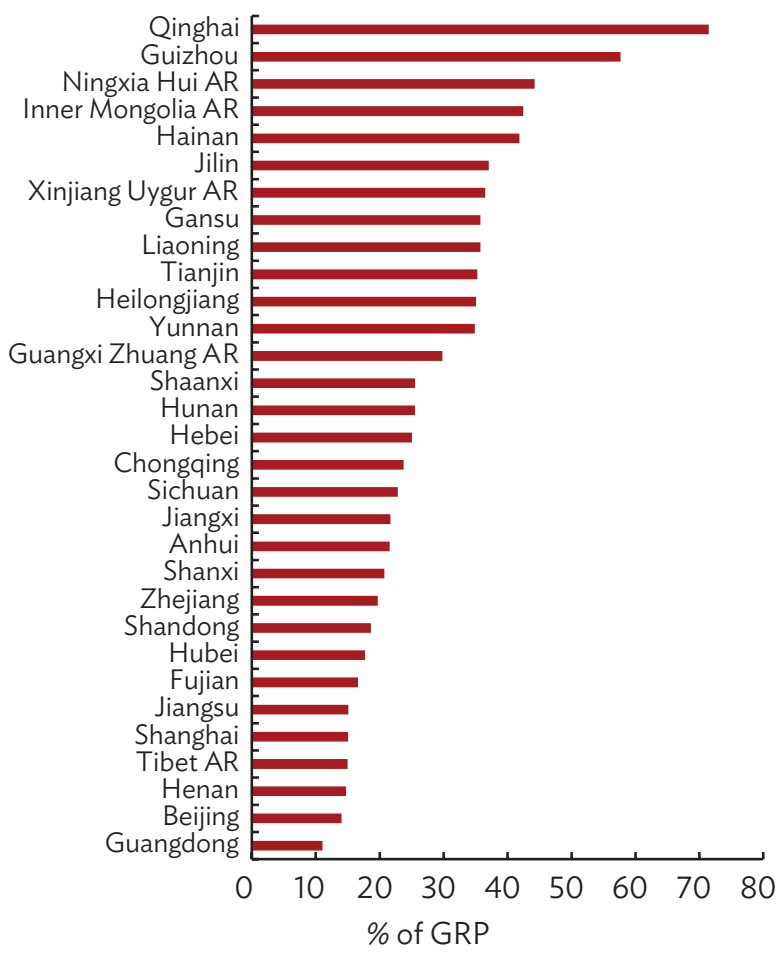

$\mathrm{AR}=$ Autonomous Region, $\mathrm{GRP}=$ gross regional product.

Note: Official debt only, calculated as the sum of general and special debt.

Sources: Ministry of Finance and National Bureau of Statistics via CEIC Data Company (accessed 13 September 2021); Asian Development calculations.

\section{B. Mounting Reform Pressure}

Pressure to reform current fiscal arrangements is mounting because growth in fiscal transfers has been slowing (except in 2020) and local government debt has increased. As noted earlier, the local government fiscal balance is deteriorating because transfers from the central government have stagnated as percentage of GDP. Total fiscal transfers cover less and less of the local government fiscal gap, with a drop in 2015 when the revised Budget Law became effective (Figure 33). However, the central government transfers most of its revenue to local governments-about $80 \%$ in recent years, which rose in 2020 because of the COVID-19 shock to the economy (Figure 34). Taken together, these findings lay bare a dilemma. Transfers cover an ever-smaller part of the fiscal gap of local governments, while the central government already spends most of its revenue on transfers - a situation that is unsatisfactory for both sides. In addition, the growth rate of central government transfers to local governments has been declining for many years, reflecting lower revenue growth (Figure 35). ${ }^{50}$

50 With COVID-19, 2020 was an exception: transfer growth accelerated, while central government revenue declined. 


\section{Figure 33: Fiscal Transfers as Percentage of Local Government Fiscal Gap, 1994-2020}



Notes: The gap is proxied by local government fiscal revenue minus fiscal expenditure. Central government transfers include tax rebates.

Sources: Ministry of Finance via CEIC Data Company (accessed 1 July 2021); Asian Development Bank calculations.
Figure 34: Fiscal Transfers as Percentage of Fiscal Revenue and Expenditure, 2007-2020

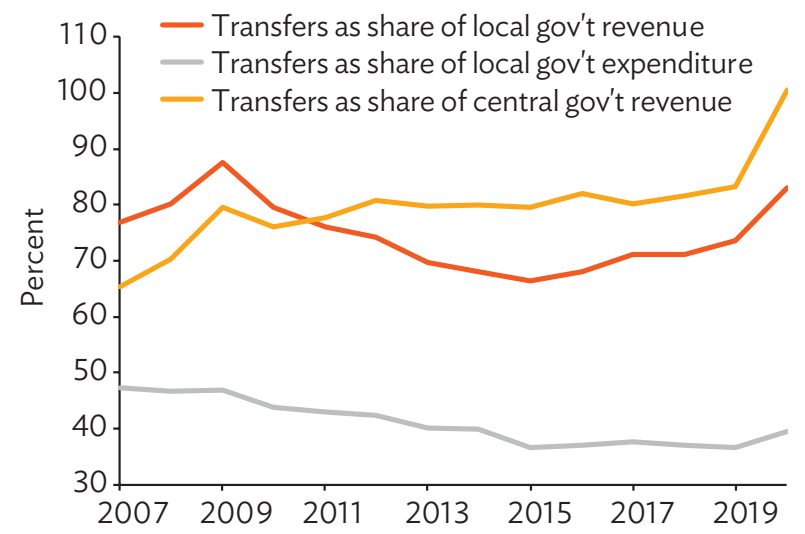

Note: Transfers include tax rebates.

Sources: Ministry of Finance via CEIC Data Company (accessed 2 July 2021); Asian Development Bank calculations.

Figure 35: Central Government Fiscal Revenue and Transfers versus Nominal Gross Domestic Product, 1995-2000

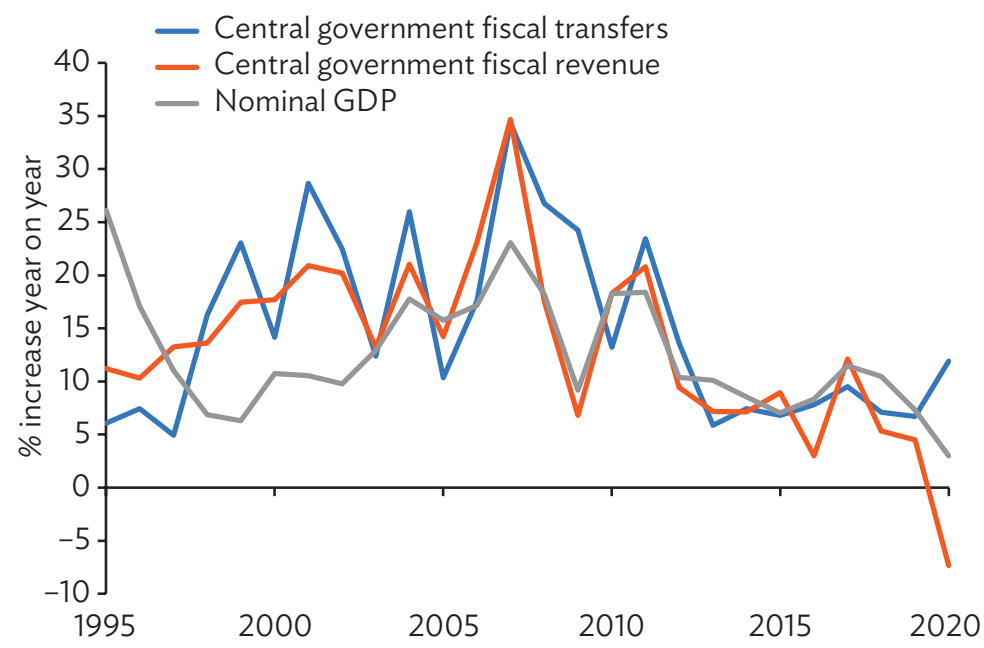

$\mathrm{GDP}=$ gross domestic product.

Notes: Includes only public finance budget. Transfers include tax rebates.

Sources: Ministry of Finance and National Bureau of Statistics via CEIC Data Company (accessed 1 July 2021); Asian Development Bank calculations. 
Two developments will put additional pressure on the central government's ability to increase transfers. Population aging will lead to an increased need for spending on health care and services for the elderly, as well as putting more pressure on public pensions. Dealing with both will require additional funding for local governments. ${ }^{51}$ At least a part of these funds will need to come from the central government either via increased transfers or by taking on more expenditure responsibilities, or a combination of both. Another source of pressure on transfer growth is slowing economic growth and the likely prospect that this trend will continue (Zhu, Zhang, and Peng 2019; Brandt et al. 2020). Fiscal revenue growth tends to moderate alongside weaker GDP growth, which implies that the fiscal space for increasing transfers will shrink-and local governments increasing their debt financing is not a sustainable solution. ${ }^{52}$

New debt issuance will likely become more challenging in the future, especially for highly indebted provinces with lower GRP per capita and those with unsustainably large fiscal deficits. Poorer provinces tend to have higher debt per capita (Figure 36), and those with bigger fiscal deficits after transfers tend to be more indebted (Figure 37), limiting their capacity to take on additional debt.

\section{Figure 36: Public Debt and Gross Regional Product Per Capita by Province, 2019}

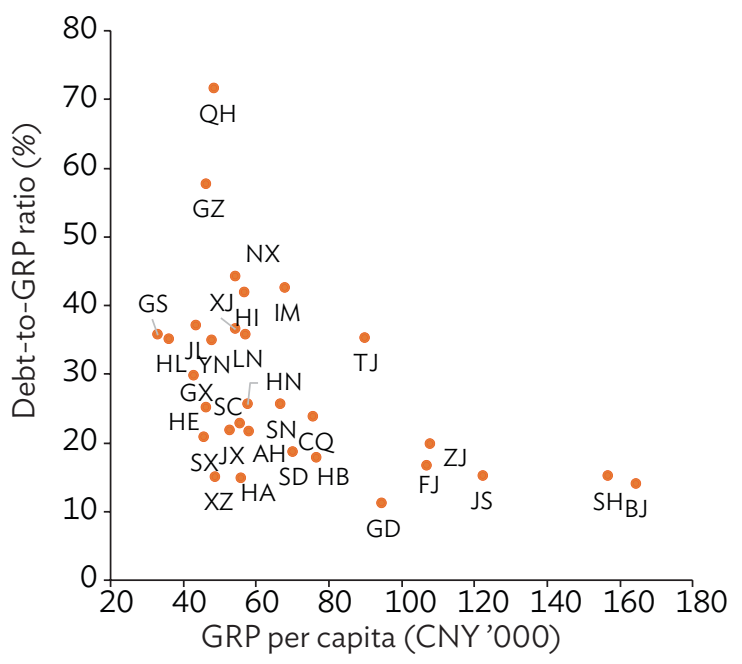

$\mathrm{AH}=$ Anhui, $\mathrm{BJ}=$ Beijing, $\mathrm{CQ}=$ Chongqing, $\mathrm{FJ}=$ Fujian, $\mathrm{GD}=$ Guangdong, $\mathrm{GRP}=$ gross regional product, $\mathrm{GS}=$ Gansu, GX = Guangxi Zhuang Autonomous Region, GZ = Guizhou, $\mathrm{HA}=$ Henan, $\mathrm{HB}=$ Hubei, $\mathrm{HE}=$ Hebei, $\mathrm{HI}$ = Hainan, $\mathrm{HL}=$ Heilongjiang, $\mathrm{HN}=$ Hunan, $\mathrm{IM}=$ Inner Mongolia Autonomous Region, JL = Jilin, JS = Jiangsu, JX = Jiangxi, $L N=$ Liaoning, NX = Ningxia Hui Autonomous Region, $\mathrm{QH}=$ Qinghai, $\mathrm{SC}=$ Sichuan, SD = Shandong, $\mathrm{SH}=$ Shanghai, $\mathrm{SN}=$ Shaanxi, $\mathrm{SX}=$ Shanxi, $\mathrm{TJ}=$ Tianjin, $\mathrm{XJ}=$ Xinjiang Uygur Autonomous Region, $\mathrm{XZ}=$ Tibet Autonomous Region, YN = Yunnan, ZJ = Zhejiang.

Note: Official public debt (general and special local government debt outstanding) only.

Sources: Ministry of Finance and National Bureau of Statistics via CEIC Data Company (accessed 23 September 2021); Asian Development Bank calculations.

\section{Figure 37: Public Debt and Fiscal Balance after Transfers by Province, 2019}

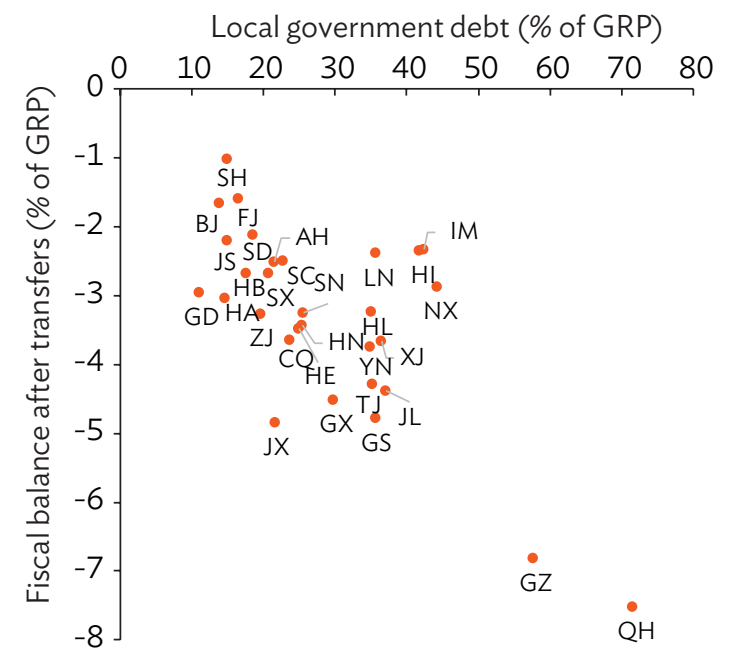

$\mathrm{AH}=$ Anhui, $\mathrm{BJ}=$ Beijing, $\mathrm{CQ}=$ Chongqing, $\mathrm{FJ}=$ Fujian, $\mathrm{GS}=\mathrm{Gansu}, \mathrm{GD}=$ Guangdong, $\mathrm{GRP}=$ gross regional product, GX = Guangxi Zhuang Autonomous Region, GZ = Guizhou, $\mathrm{HA}=$ Henan, $\mathrm{HB}=$ Hubei, $\mathrm{HE}=$ Hebei, $\mathrm{HI}$ = Hainan, $\mathrm{HL}=$ Heilongjiang, $\mathrm{HN}=$ Hunan, $\mathrm{IM}=$ Inner Mongolia Autonomous Region, JL = Jilin, JS = Jiangsu, JX = Jiangxi, LN = Liaoning, NX = Ningxia Hui Autonomous Region, $\mathrm{QH}=$ Qinghai, $\mathrm{SC}=$ Sichuan, $\mathrm{SD}=$ Shandong, $\mathrm{SH}$ = Shanghai, $S N=$ Shaanxi, $S X=$ Shanxi, TJ = Tianjin, $X J$ J = Xinjiang Uygur Autonomous Region, $Y N=$ Yunnan, $Z \mathrm{~J} \mathrm{=}$ Zhejiang.

Notes: Official public debt only. Tibet Autonomous Region data are an outlier and not included.

Sources: Ministry of Finance. http://yss.mof.gov.cn/2019qgczjs/ (accessed 13 September 2021); Ministry of Finance and National Bureau of Statistics via CEIC Data Company (accessed 23 September 2021); Asian Development Bank calculations.

51 The central government requires that growth in local government expenditure on health and medical care not to be lower than that of fiscal expenditure (Qiao et al. forthcoming).

52 Central government fiscal revenue is also prone to economic shocks as it highly relies on indirect tax income (e.g., VAT), which in turn depends on economic activity that decreases rapidly during recessions (Fan and Wan 2017). 


\section{Fiscal Expenditure Responsibilities}

In 2016, the State Council announced reforms in its Guiding Opinions on Advancing the Reform of the Division of Revenue Assignments and Expenditure Responsibilities between the Central and the Local Governments to clarify expenditure responsibilities between the central government and local governments. The aim was to minimize joint responsibilities, centralize key functions at the level of central government, and consolidate and enhance the fiscal transfer system to strengthen the financial resources of less-developed regions.

The gap in fiscal expenditure between the central government and local governments is significant. Central government fiscal expenditure, excluding transfers, was the equivalent of 3.5\% of GDP in 2019 and at $20.6 \%$ of GDP for local government. Hence, central government accounted for less than $15 \%$ of general government expenditure, virtually the same level as in 2015. This is much lower compared with OECD countries, where central government spent on average $41.3 \%$ of general government expenditure, including social security, in 2019 (OECD 2021b).

According to 2016's Guiding Opinions, the central government is responsible for national security, foreign affairs, migration, national transportation infrastructure, and natural resources, while local governments are responsible for local public services and facilities, public security, and municipal transportation and infrastructure. Areas of joint mandate include science and education, research and development, social security (pension, health, and unemployment), food security, and environmental protection. The delivery of basic public services remains with local governments. On financing, the Guiding Opinions did not grant own-revenue sources to local governments.

The delineation of joint responsibilities started in 2016 with national defense and state security (Qiao et al. forthcoming). This was followed by the delineation of basic public services, health, science and technology, education, transport, environmental protection, culture, emergency response, and natural resources (State Council 2018a-b, 2019a-c, 2020a-d). Eighteen public service categories, many of them critical to people's well-being, remain classified as joint fiscal expenditures, including compulsory education, student subsidies, employment services, pensions, basic medical insurance, health and family planning, living assistance, and affordable housing (State Council 2018a).

The central government divided 31 province-level entities and five specially designated cities (Dalian, Ningbo, Qingdao, Shenzhen, Xiamen) into five categories according to their financial situation to determine the central government's financial support, with poorer regions receiving more grants for seven basic public services for education, basic medical insurance, and public health services. The central government's share differs as follows: $80 \%$ for 12 entities ( 5 autonomous regions and 7 provinces in the western inner region), $60 \%$ for another 10 provinces in the middle north-south zone, $50 \%$ for 3 eastern coastal provinces, 30\% for another 3 eastern coastal provinces and 5 specially designated cities plus Tianjin, and 10\% for Beijing and Shanghai (Chan 2019). The central government's share is different for subsidies ensuring the minimum basic pension for urban and rural residents. It covers $100 \%$ for provincelevel entities in the two poorest categories and 50\% for the remaining ones (State Council 2018a).

This paper recommends that the expenditure responsibilities between the central and local governments are further clarified and joint areas of responsibility are reduced as much as possible. This could help reduce the unnecessary multiplication and overlapping of administrative procedures (Sow and Razafimahefa 2017). Qiao et al. (forthcoming) point out that the lack of legal norms in expenditure assignments leads to responsibilities ending up at the local level. And most of these will remain there because delineations of responsibilities tend to be incomplete or not sufficiently clear, especially in complex areas, such as the delivery of basic public services. In the end, it is frequently local government that needs to take action.

Progress is needed in the centralization of some responsibilities. Central government expenditure in joint-mandate areas remains scant. The expenditure of local governments on health, education, and 
social security and employment has been rising slightly, accounting for about $38 \%$ of their fiscal spending (equivalent to $7.9 \%$ of GDP) in 2019 (Figure 38). Yet, the central government spent only about $9 \%$ of its expenditure (0.3\% of GDP) on these categories in 2020 (Figure 39).

\section{Figure 38: Breakdown of Local Government Fiscal Expenditure, 2007-2019}

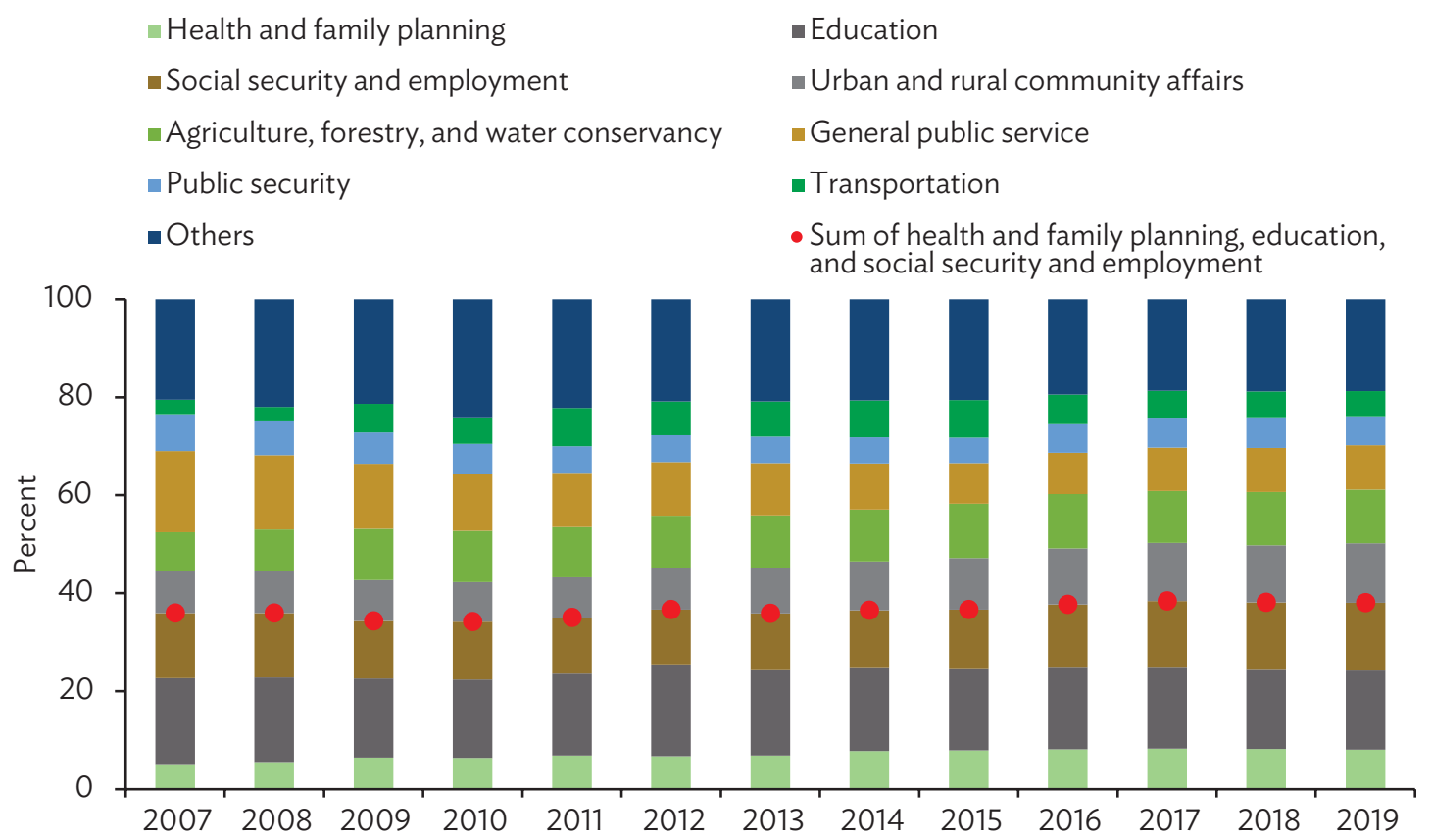

Notes: Local government expenditure was equivalent to 7.9\% of gross domestic product in 2019. 2019 data used to avoid distortions from COVID-19.

Sources: Ministry of Finance via CEIC Data Company (accessed 2 July 2021); Asian Development Bank calculations.

Figure 39: Top 10 Central Government Fiscal Expenditure, 2020

(\% of total expenditure)

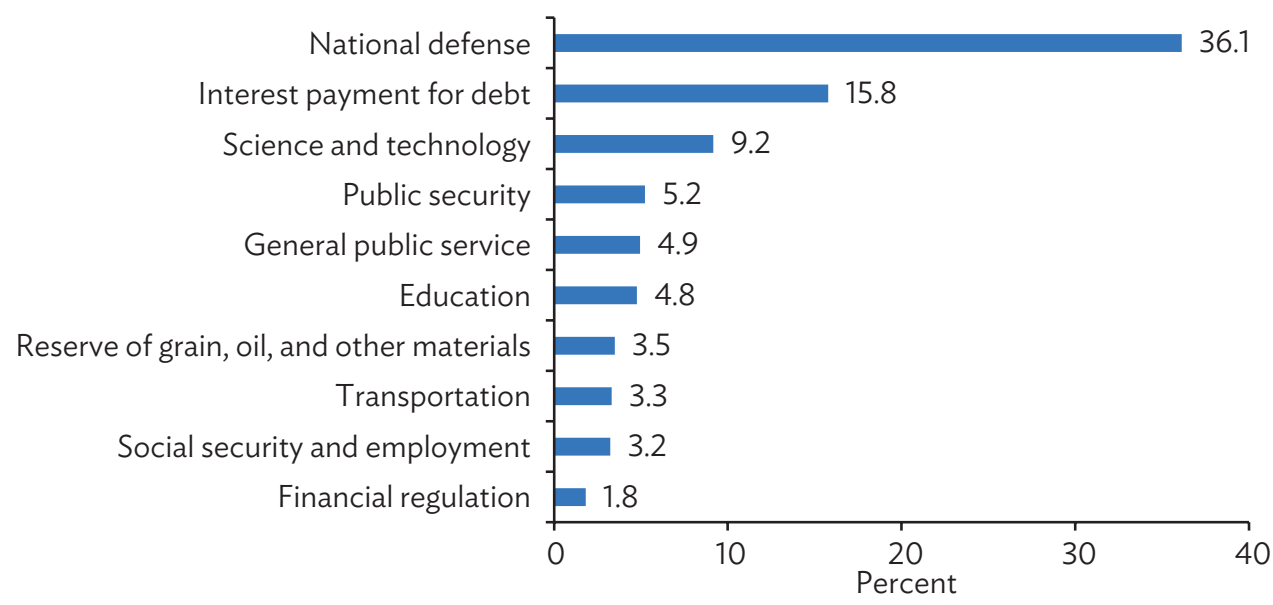

Notes: Health expenditure at $1.0 \%$ of fiscal expenditure is not in the top 10 expenditure categories. Central government total fiscal expenditure was equivalent to 3.5\% of gross domestic product in 2020 .

Sources: Ministry of Finance via CEIC Data Company (accessed 2 July 2021); Asian Development Bank calculations. 
The role of central government should be strengthened in areas where a centralized approach is international best practice and brings efficiency gains. For instance, the centralization of pension insurance for urban employees, including national revenue pooling, would bring about efficiency gains in collection and administration-and have an element of redistribution (ADB 2019, 2020a). Implementing this reform would align the PRC with international best practice since pension insurance is usually a central government responsibility (Dollar and Hofman 2006; ADB 2014b; Wingender 2018). Unemployment insurance is also generally centralized internationally (Dollar and Hofman 2006; Wingender 2018); this provides automatic stabilization in economic downturns when unemployment rises (Wingender 2018). But even with these changes in fiscal responsibilities, the central government's expenditure share would still be moderate by international comparison because the PRC is extremely decentralized in fiscal expenditure. ${ }^{53}$

International practice varies widely on health care. For increasing public spending on health, the PRC would need to overcome the fragmentation and low coverage rates of its public health care system. Higher transfers from the central government to fund the budgetary health-care outlays of local governments will be crucial for increasing coverage and reducing individuals' out-of-pocket health care expenses (Wingender 2018).

For other areas, clarity of function may be more important than assigning exactly the best level for a task (Dollar and Hofman 2006; Bahl, Goh, and Qiao 2014).

In sum, the main recommendations on assigning fiscal expenditure are:

(i) Expenditure responsibilities should be delineated as clearly as possible. Ideally, the scope of joint responsibilities would be reduced.

(ii) Following efficiency considerations, some fiscal responsibilities, especially pensions and unemployment insurance, should be elevated to central government.

(iii) Some basic public services, such as primary health care, should not be centralized, but the central government should ensure local governments provide them at a satisfactory standard. To this end, an increase in fiscal transfers from the central government to local governments is needed, but these funds must be used properly, as discussed in the next section.

\section{Fiscal Transfers}

This section offers recommendations to improve the fiscal transfer system for the overall size of transfers and their distribution by province, and to improve the system's efficiency.

\section{Size of fiscal transfers and their distribution}

For a substantial increase in fiscal transfers, the central government will need a higher fiscal surplus to avoid debt financing. In 2020, its fiscal revenue, equal to 8.1\% of GDP, exceeded its expenditure, at 3.5\% of GDP (before transfers but including debt service), by $4.7 \%$ of GDP, while the local government budget deficit was $10.9 \%$ of GDP. The central government's total fiscal transfers to local governments, at $8.2 \%$ of GDP, exceeded the central government's entire fiscal revenue. In 2019, the year before the COVID-19 crisis, the situation was, however, slightly better.

53 OECD and UCLG (2019) find the PRC has the highest share of subnational expenditure in total general government expenditure of countries covered in their study and ranks also comparatively high in subnational tax revenue. 
The current level of fiscal transfers to local governments, at about $8 \%$ of GDP, has not been enough for them to fund their fiscal expenditure without accumulating additional debt. The goal should be sufficient transfers to fund legitimate expenditure without local governments accumulating more debt (ADB 2015a). Currently, no fiscal space exists to increase transfers without incurring more debt at either level of government. Thus, fiscal revenue must be strengthened to make room for additional transfers.

For the distribution of fiscal transfers, poorer provinces tend to receive higher transfers per capita (Figure 40). ADB (2014) estimates that raising the fiscal resources of local governments to the national average would require a $27 \%$ increase in transfers with 13 provinces receiving additional transfers. Such a large increase was judged as likely unaffordable, and some redistribution of transfers from fiscally richer to poorer provinces would be required.

\section{Figure 40: Fiscal Transfers to Provinces and Gross Regional Product Per Capita, 2019}



$\mathrm{AH}=$ Anhui, $\mathrm{BJ}=$ Beijing, $\mathrm{CQ}=$ Chongqing, $\mathrm{FJ}=$ Fujian, $\mathrm{GS}=\mathrm{Gansu}, \mathrm{GD}=$ Guangdong, GRP = gross regional product, $\mathrm{GX}=$ Guangxi Zhuang Autonomous Region, $\mathrm{GZ}=$ Guizhou, $\mathrm{HA}=$ Henan, $\mathrm{HB}=$ Hubei, $\mathrm{HE}=$ Hebei, $\mathrm{HI}=$ Hainan, $\mathrm{HL}=$ Heilongjiang, $\mathrm{HN}=$ Hunan, IM = Inner Mongolia Autonomous Region, JL = Jilin, JS = Jiangsu, JX = Jiangxi, LN = Liaoning, NX = Ningxia Hui Autonomous Region, $S C=$ Sichuan, SD = Shandong, SH = Shanghai, SN = Shaanxi, SX = Shanxi, TJ = Tianjin, XJ = Xinjiang Uygur Autonomous Region, YN = Yunnan, ZJ = Zhejiang.

Note: Data for Tibet Autonomous Region and Qinghai are outliers and excluded in the chart.

Sources: Ministry of Finance. http://yss.mof.gov.cn/2019qgczjs/ (accessed 13 September 2021); National Bureau of Statistics via CEIC Data Company (accessed 13 September 2021); Asian Development Bank calculations. 
The central government will need to reduce transfers to wealthy provinces to gain the fiscal space to increase transfers to poorer ones. Wealthier provinces could be partly compensated by introducing a property tax that would be local government revenue. As housing prices tend to be higher in wealthy municipalities and provinces, those would profit more than poorer ones.

\section{Efficiency of the transfer system}

In addition to the overall volume of transfers and their distribution, transfers need to be efficient, which is closely related with the composition, types, and aims of transfers. ${ }^{54}$

Intergovernmental transfers used to be accounted for in three categories: special transfers, general transfers, and tax rebates, with some of these transfers being conditional and others not (Bahl, Goh, and Qiao 2014). Despite being counter-equalizing, tax rebates were introduced to compensate richer provinces for revenue losses following the 1994 fiscal reforms. Their share in transfers has diminished over time, while the share of general transfers-with equalizing transfers (i.e., those designed to reduce fiscal disparities among provinces) being part of that category-has increased over time (Figure 41).

\section{Figure 41: Breakdown of Central Government Fiscal Transfers by Type, 1995-2018}

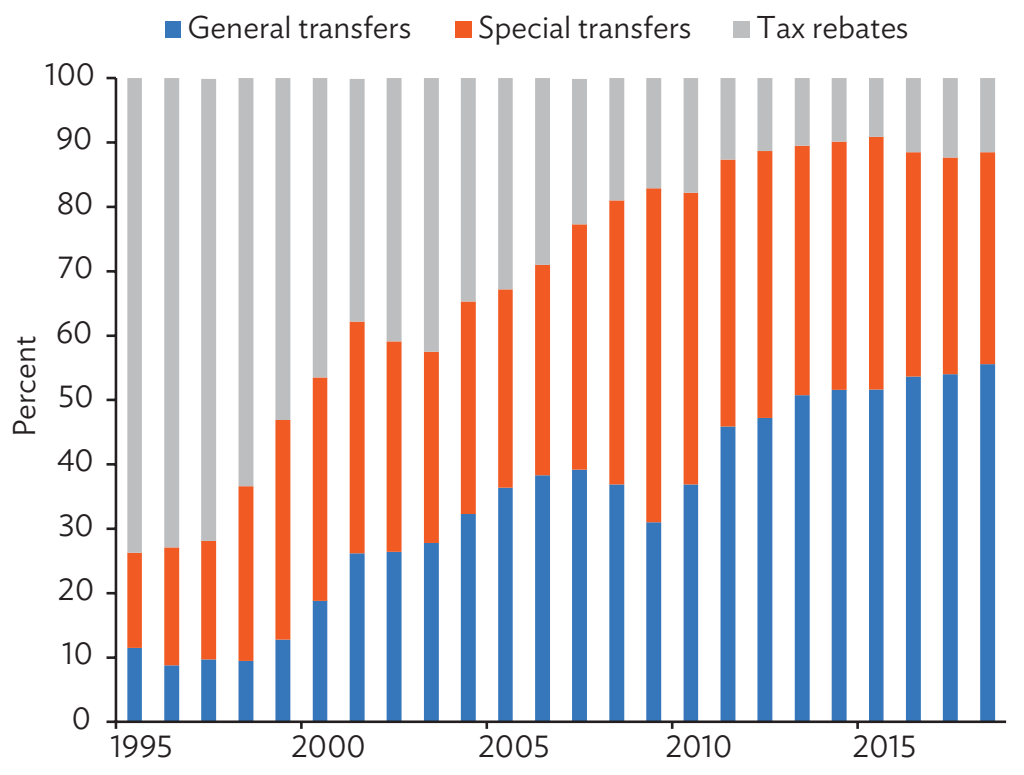

Notes: Data before 2008 from Y. Wu et al. 2017. Transfer Payment Structure and Local Government Fiscal Efficiency: Evidence from China. China Finance and Economic Review. 5 (12). Categorization changed after 2018.

Sources: Ministry of Finance via CEIC Data Company (accessed 2 July 2021); Wu et al. (2017); Asian Development Bank calculations.

The transfer system was reformed in 2019. Tax rebates were put under general purpose transfers, a new type of shared-function transfers was introduced, and related old transfer schemes (general and special) were subsumed under this new category, which is temporarily classified under general transfers. The new model of transfers still needs to be improved in scale, mode, and policy coordination (Qiao et al. forthcoming).

54 As well as their gap-filling role, transfers can fulfil three purposes: equalization, positive spillovers, and ensuring national standards (Boadway and Eyraud 2018). In the PRC, ensuring national standards for the delivery of basic public services and social security could help reduce regional disparities in living standards. 
Three areas warrant further attention: the transfer mix and budget accountability, evaluating the performance of fiscal transfers and budget management, and formalizing subprovincial transfers.

(i) Transfer mix and budget accountability. Increasing fiscal transfers, especially unconditional ones, could encourage local governments to spend money inefficiently because they are not responsible for financing the outlays. But hard budget constraints tend to be difficult to impose when local governments heavily depend on transfers (ADB 2014b; Wingender 2018). Assigning own-source revenue to local governments is one solution to potentially increase their accountability (Wingender 2018; Qiao et al. forthcoming). Because local governments would have to finance improvements in public services through higher taxes, local fiscal expenditure would be linked to local revenue. This link, however, is still no guarantee that additional funds will be exclusively used for improving public services. Furthermore, granting own-revenue sources to local governments will likely have counter-equalizing effects that need compensating, an issue discussed in greater detail in the next section (E).

(ii) Evaluating the performance of fiscal transfers and budget management. Evaluation has so far primarily focused on special purpose transfers, but the disclosure of information on expenditure performance remains insufficient (Qiao et al. forthcoming). Because the system needs to further reduce the number of targeted transfers and to simplify these transfers, which are complex and costly to administer, greater emphasis should be put on the quality of public services (ADB 2014b; Wingender 2018). The budget management and transparency (information, evaluation) of local governments needs strengthening to increase accountability in their delivery of public services.

(iii) Formalizing subprovincial transfers. Provincial-level entities, within their jurisdiction, share revenue and arrange transfers at their discretion (OECD 2017). To make a system of revenue, expenditure, and subprovincial transfers work properly, related rules need to be developed and implemented at the province level. Failure to do this could result in the replay of the problem of a higher administrative level setting the rules and lower levels having to deal with the implications. Subprovincial accountability mechanisms need strengthening to ensure that transfers are properly used. Local government at the subprovincial and provincial levels also need incentives to be able to properly weigh spending on economic development and construction against spending on social areas (Martin-Velasquez and Qiao 2010).

\section{Summary of recommendations}

The main recommendations for improving the efficiency of fiscal transfers are:

(i) General fiscal transfers to poor provincial governments should be increased to narrow the fiscal gap (equalization goal). Wealthy provincial administrations should get less transfers, but, as a compensation, they would profit more from the rollout of a nationwide recurrent property tax (section E).

(ii) Shared-function transfers should focus on providing better basic public services. Transfers to poorer provinces need to be increased, but, at the same time, the provision of better public services needs ensuring. This will require increased accountability at the local level and these services being measured and evaluated. Budget management and transparency at the local level should be strengthened to enhance accountability.

(iii) A system for subprovincial transfers should be gradually introduced and formalized. 


\section{E. Local Government Fiscal Revenue}

This section discusses reform options to strengthen local government fiscal revenue. It covers tax revenue and the tax sharing system, assesses reform options for the system, and analyzes the potential effects of introducing local government own-source taxes.

\section{Tax revenue and sharing}

Increasing tax revenue, both at central and local level, is crucial to enable the central government to increase fiscal transfers and to narrow the local government fiscal gap. ${ }^{55}$ Tax collection in the PRC is low compared to OECD countries. In 2019, tax revenue, including social security contributions, in OECD countries averaged the equivalent of $33.8 \%$ of GDP; in the PRC, it was $22.1 \%$ of which 16.0 percentage points were taxes and 6.1 points social security contributions (OECD 2021c).

The current tax sharing system in the PRC has resulted in the central government receiving proportionally higher tax revenue-equal to $8.2 \%$ of GDP-compared with local governments (7.8\%) (Figures 42 and 43).
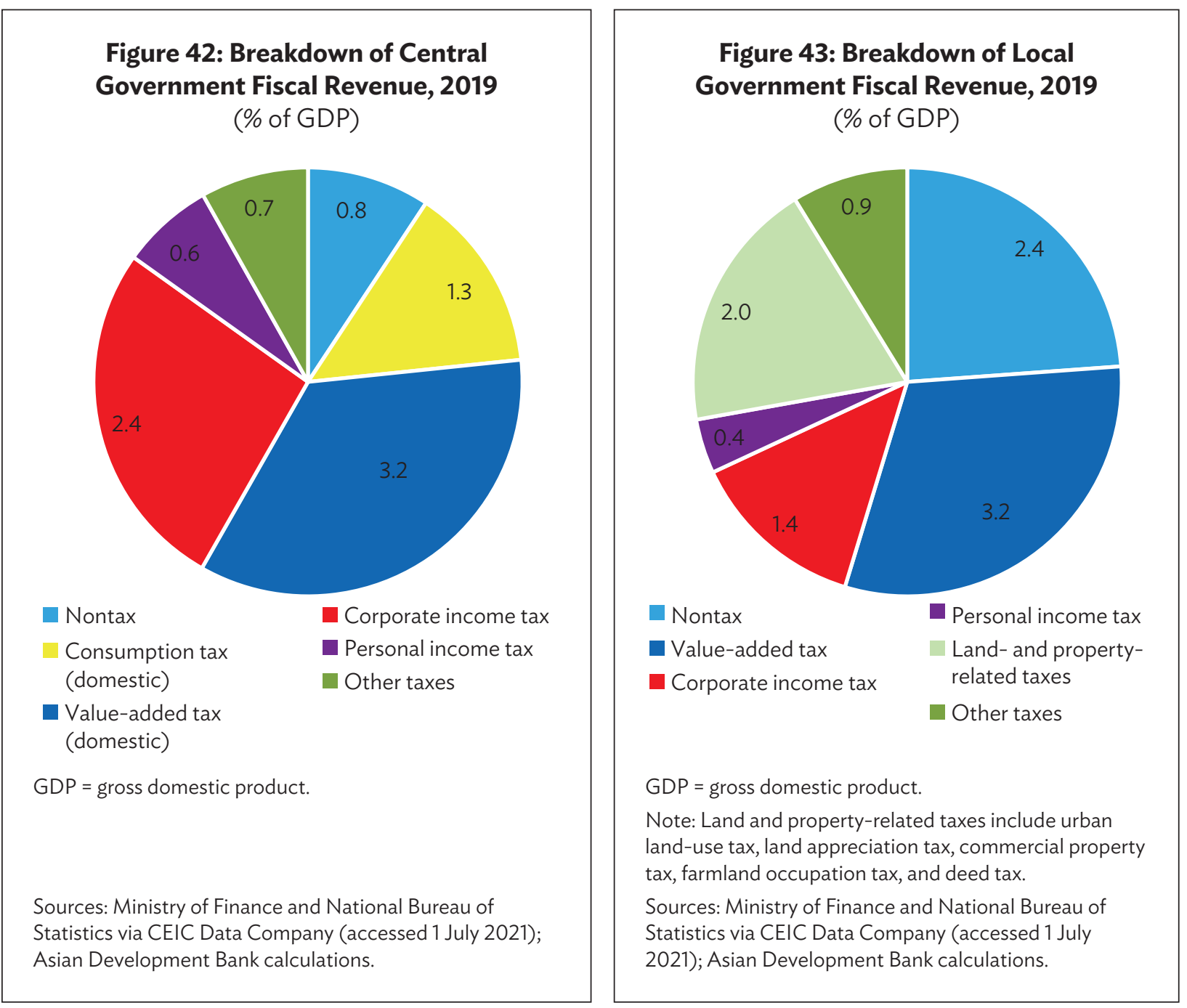

55 The extent to which transfers to local governments need to be increased depends on many factors, including the central government taking on more expenditure responsibilities (section C), the envisaged level of redistribution via fiscal transfers and the ability of the central government to actually finance these transfers (section D), and local government fiscal revenue (section E). 
Major taxes are shared between the central government and local governments as follows: VAT (50/50), corporate income tax (CIT) (60/40), and PIT (60/40). ${ }^{56}$ The substantial revenue share of the central government stems from its share in VAT and CIT. Taxes exclusively assigned to local government tend to be insignificant unless the five land- and property-related taxes are considered combined.

The current derivation-based revenue sharing system-one where the amount of transfers received by a region is proportionate to the share of taxes collected there-engrains the focus of local governments on competing for investment to generate CIT revenue (Bahl 2019). This is not surprising when looking at tax revenue: CIT is a much bigger revenue source than PIT (VAT is the biggest) in the PRC, where CIT accounted for $23.6 \%$ of total tax revenue in 2019. In OECD countries, CIT in 2018 only accounted on average for $10.0 \%$ of total tax revenue, including social security contributions, or $3.1 \%$ of GDP (OECD 2020)..$^{57}$

Although the PRC's tax sharing system mobilizes investment, it leaves local governments vulnerable to central government-mandated cuts in the tax base, as well as to adjustments to their share in taxes (Bahl 2019).$^{58}$ It is also an incentive for local governments not to increase and strictly enforce minimum wages, as this might impede local economic growth and investment, thereby lowering local CIT revenue. ${ }^{59}$ In sum, the current system prioritizes efficient tax collection over income redistribution (Qiao et al. forthcoming).

\section{Reform options for the tax sharing system}

The tax sharing system favors provinces with bigger tax bases. Not all taxes have the same revenue potential, which distorts incentives, such as competing for local corporate tax bases. Changing the tax sharing system could potentially help local governments, but this is difficult to implement, as the following three options discussed in the literature show:

(i) Shift in revenue shares. Here, provinces would receive a higher tax share and the central government a lower one. This shift, however, would disproportionally benefit local governments with higher tax bases (Figure 44), which would be counter-equalizing and require compensation for provinces with weaker tax bases.

Zhang and Li (2017) suggest shifting PIT collection completely to local governments. Given the size of their budget deficits, such a move would still be insufficient in revenue terms, especially without broadening the tax base and increasing progressivity, as discussed earlier. The ensuing revenue shortfall on the central government side is another issue to take into account. Changes to the current tax sharing system can be considered to finetune local government revenue.

56 Qiao et al. (forthcoming) also provide an overview on exceptions, which especially affect CIT sharing.

57 VAT accounted on average for $20.4 \%$ of total tax revenue (including social security contributions), or $6.8 \%$ of GDP, in OECD countries in 2018 (OECD 2020).

58 A needs-based formula for transfers instead of the current tax sharing system would lessen the incentives for subnational governments to compete for tax bases (World Bank and DRC 2019).

59 Local governments have room to increase minimum wages, which-measured as a ratio of local minimum wages to local average wages - tend to be low compared with OECD countries (OECD 2017). 


\section{Figure 44: Tax Revenue by Province and Gross Regional Product Per Capita, 2019}

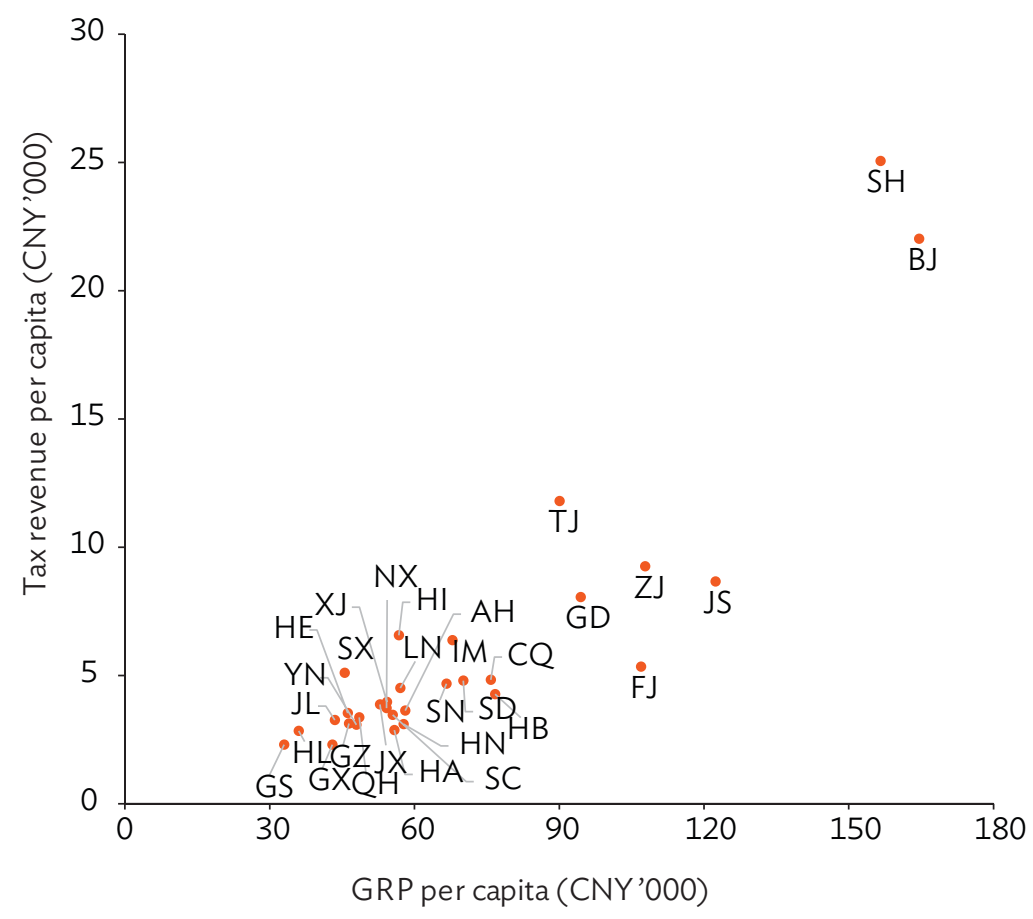

$\mathrm{AH}=$ Anhui, $\mathrm{BJ}=$ Beijing, $\mathrm{CQ}=$ Chongqing, $\mathrm{FJ}=$ Fujian, $\mathrm{GS}=\mathrm{Gansu}, \mathrm{GD}=$

Guangdong, $\mathrm{GRP}$ = gross regional product, $\mathrm{GX}=$ Guangxi Zhuang Autonomous Region, $\mathrm{GZ}=$ Guizhou, $\mathrm{HA}=$ Henan, $\mathrm{HB}=$ Hubei, $\mathrm{HE}=$ Hebei, $\mathrm{HI}=$ Hainan, $\mathrm{HL}=$ Heilongjiang, $\mathrm{HN}=$ Hunan, IM = Inner Mongolia Autonomous Region, JL = Jilin, JS = Jiangsu, JX = Jiangxi, LN = Liaoning, NX = Ningxia Hui Autonomous Region, $Q H$ = Qinghai, $S C=$ Sichuan, $S D$ = Shandong, $S H$ = Shanghai, $S N=$ Shaanxi, SX = Shanxi, $\mathrm{TJ}=$ Tianjin, $\mathrm{XJ}=$ Xinjiang Uygur Autonomous Region, $\mathrm{YN}=$ Yunnan, $\mathrm{ZJ}=$ Zhejiang. Note: Tibet Autonomous Region data are an outlier and not included in the chart.

Sources: Ministry of Finance and National Bureau of Statistics via CEIC Data Company (accessed 13 September 2021); Asian Development Bank calculations.

(ii) Single sharing rate with a vertical revenue pool. Bahl, Goh, and Qiao (2014) suggest reforming the revenue sharing system by having a single sharing rate for a vertical pool. This would include all taxes where the rate is set by the central government-and by implication cover virtually all tax revenue. Here, subnational governments would receive a fixed share of that pool, and not, as is currently the case, different sharing rates for each tax. A system with a single rate would be non-distortionary in terms of the type of tax and be easy to administer. This system, however, has drawbacks. The central government might be tempted to frequently change the general sharing rate. It would also lose the ability to fine-tune the revenue flow to local governments by increasing their share in a specific tax category, as is the current practice.

(iii) Horizontal revenue sharing across provinces. Bahl, Goh, and Qiao (2014) and World Bank and DRC (2019) consider a horizontal sharing pool among provinces. Doing this would, however, change the nature of the intergovernmental transfer system and be politically contested as richer provinces (those with a high tax base) would likely end up losing revenue. This approach would also necessarily eliminate the entitlement to share 
revenue raised at the local level, thereby eliminating incentives for local governments to increase the rate of revenue mobilization. Because this is generally weak in the PRC compared with internationally, making this change would very likely increase pressure on the system.

In sum, because any fundamental change to the current tax sharing system would have major implications, it would require detailed consideration, preparation, and political negotiation. Even if it is put on the agenda, it would likely take years for major changes to become fully effective given the complexity of changing the tax sharing system.

\section{Own-source revenue}

The extent to which revenue should be decentralized is generally a political choice, but this choice nevertheless has implications for central-local fiscal relations and their reform. ${ }^{60}$ Sizable own-source tax revenue - that is, revenue raised by a government from imposing a tax on its own - at the level of local government would reduce the need for fiscal transfers (and vice versa). So, why have local government own-source taxes not already been introduced?

One difficulty has been finding a good source of local tax revenue that can be administered at a reasonable cost, yield significant revenue, and does not result in exporting the burden of payment to residents of other jurisdictions (Bahl, Goh, and Qiao 2014). The local tax source should also be stable and tax bases not unevenly distributed (Arora and Norregaard 1997). The latter is an important point for the PRC because of its vast regional disparities.

Granting local governments own-source revenue, even within narrow limits, would lead to some degree of tax autonomy. Because the local government budget deficit is sizable, the revenue potential of ownsource taxes would need to be significant. Tax autonomy, even within limits, would entail risks - and if it failed, regional disparities could even widen. Poor local governments would need to levy higher taxes, but end up providing subpar public services. If that happened, people might migrate from these regions and the remaining population would have to cover the outstanding local government debt-and poorer regions tend to have higher per capita public debt.

Significant own-source tax revenue would enable local governments to raise revenue independently from the central government. Revenue autonomy nevertheless comes with administration costs. So, using a centrally legislated tax base to levy a local tax within specified limits-piggybacking, in other words-would help limit administration costs. This would work best at the provincial level as lower levels of administration might face high administration costs. These levels should therefore rely more on improved transfers and the allocation of specific taxes (ADB 2015b). An example of such a tax is the proposed nationwide recurrent property tax.

Piggyback taxes also have drawbacks. From an equity standpoint, there is a danger that revenueconstrained local governments will maximize tax revenue without improving basic public services. Granting local governments taxation powers could increase disparities by catalyzing the migration of qualified workers from poorer to richer regions. Because the PRC's household registration system (hukou) still ties many access rights to the place of official residence, mobility is limited, especially for those who depend on public social services. These people would benefit from increased fiscal transfers to poorer regions.

60 For the degree of revenue (de)centralization, the case is different from expenditure (de)centralization. For revenue, the case for (de)centralization is often less clear. While tax administration costs play a role, the level of redistribution via fiscal transfers also depends on equalization efforts and national standards, both of which are frequently subject to political considerations. 
Which taxes are potentially suitable as local government own-source revenue besides property taxes? In the literature, ${ }^{61}$ mostly three piggyback taxes and surcharges ${ }^{62}$ - on CIT and PIT, and on a national carbon tax-are discussed.

(i) Piggybacking on corporate income tax. This could be challenging because it is often difficult to determine where corporate profit is actually generated (ADB 2014b) - and local governments already intensively compete for firms to locate in their jurisdiction because of the current tax revenue sharing system. Local governments being able to levy additional taxes on the CIT base would intensify this competition, which could lead to a race to the bottom where richer local governments do not piggyback on CIT and thereby force others to do the same to remain competitive.

The central government stipulating strictly positive minimum rates or fixing rates in the case of a CIT surcharge would increase CIT rates. The PRC's standard PIT rate of $25 \%$ is in line with the Asian and the global GDP-weighted average of statutory corporate tax rates (Asen 2020). Also, the tax base of CIT is very unevenly distributed across the PRC. For all these reasons, piggybacking on CIT has drawbacks that will be difficult to overcome.

(ii) Piggybacking on a national carbon tax for fossil fuel carbon emissions. ${ }^{63}$ Doing this would require a national carbon tax to be implemented in the first place, which seems unlikely. The central government would also probably need to stipulate minimum rates to prevent a race to the bottom for the same reasons mentioned in the previous point on piggybacking on CIT. In 2021, the PRC started a carbon emission trading scheme for the energy sector, and its scope will be gradually broadened to more sectors. Since the scheme will be expanded, the political room to enact a national carbon tax should shrink. Although it is not realistic to expect a national carbon tax, one would nevertheless be favorable for at least two reasons: facilitating the transition to a zero-carbon economy and providing additional revenue. Even though the chances of a national carbon tax are low right now, the proposal could be revisited, especially if the expansion of the carbon emission trading scheme to other sectors gets delayed.

(iii) Piggybacking on personal income tax. ${ }^{64}$ Provinces could piggyback on PIT within a band set by the central government, which could incentivize them to collect PIT by using their information on rich residents, including their sources of nonwage income. But because rich people tend to live in more developed neighborhoods, piggybacking on PIT could increase spatial inequalities, which would require a refined fiscal equalization framework that takes into account differences in own-revenue bases (Ahmad, Neuweg, and Stern 2018).

The danger also exists that poorer local governments would need to make use of all available taxation possibilities, while richer ones would not need to do this. Hence, the PIT burden in economically weaker regions would be higher than in more prosperous ones, which would

61 See for instance ADB (2014), Bahl, Goh, and Qiao (2014), Morgan and Trinh (2016), Ahmad, Neuweg, and Stern (2018), Ahmad (2019), and Qiao et al. (forthcoming).

62 Piggybacking on a national tax means using a central government-defined tax base, which local governments use to levy taxes. Local governments can set, within limits, the tax rate. If the central government sets a percentage surcharge, local governments would not have discretion to set rates, as is the case with the urban construction and maintenance tax, and the educational surtax.

63 Discussed in greater detail in Ahmad, Neuweg, and Stern (2018) and Ahmad (2019).

64 This is often proposed in the literature. See for example ADB (2014b), Bahl, Goh, and Qiao (2014), Ahmad, Neuweg, and Stern (2018), and Ahmad (2019). 
run contrary to equalization and redistribution efforts..$^{65}$ These effects could be aggravated by hukou restrictions remaining in place, especially for rich municipalities, such as Beijing and Shanghai. If residents have lower surcharge rates than poorer provinces, those in richer regions would pay lower taxes than those in poorer ones at the same level of income. This would be very hard to justify. Fiscal transfers to compensate poorer provinces would also need to be calibrated in a way that takes into account the potential for own-revenue and not actual tax collection in case richer provinces choose surcharge rates lower than the maximum allowed. In other words, differentiated sur-rates would bring several challenges.

Because of this, the central government would need to fix surcharge rates, resulting in a fixed percentage surcharge. Although this would weaken the link between local government fiscal revenue and expenditure with the aim of achieving greater local government accountability, the calculation of extra revenue would be simple. Wealthier provinces would also benefit more, which could compensate them for lower fiscal transfers as the central government increases these transfers to poorer provinces, financed by a reduction in transfers to wealthier provinces.

Introducing a PIT surcharge or increasing the PIT tax share of local governments-while in both cases compensating provinces with weaker tax bases-would lead to higher revenue at the local level. The PIT surcharge would, however, also increase the tax burden of PIT payers, while changes to the weights in the tax sharing system would shift revenue distribution. However, PIT reforms to broaden the tax base remain key for increasing revenue in the first place so that the potential additional revenue for local governments would be meaningful. And with the current PIT base heavily dependent on wage income, adding a surcharge would put wage earners at a disadvantage.

Overall, reforms to PIT, including widening the tax base and increasing its progressivity, should lay the foundation for further adjustments, such as changing the share of PIT that local governments receive or adding a surcharge. A surcharge on PIT, offset by increased transfers to fiscally weaker provinces, remains an interesting option as a part of broader reforms.

\section{Summary of recommendations on the revenue side}

Enacting major shifts in the tax sharing system is not recommended, but fine-tuning the rates for shared taxes could be considered to balance local government budgets on the margin. More importantly, a nationwide recurrent property tax should be rolled out at the local level.

Raising local government revenue by piggybacking on existing taxes is fraught with difficulties. But a potential tax for piggybacking would be a national carbon emission tax, which is not in place. Piggybacking on PIT in its current form has very limited revenue potential. Because of this, further reforms to increase the revenue potential of PIT remain essential. Because a surcharge on PIT would disproportionally benefit wealthier municipalities and provinces, poorer provinces would need to be compensated by an increase in fiscal transfers financed by a reduction in those to wealthier regions.

A key issue is to raise overall tax revenue. The sharing of additional revenue can be adjusted through fine-tuning the tax sharing system and fiscal transfers.

65 Granting local governments tax autonomy could end up in a Matthew effect, similar to social security contributions. Before employers' pension contributions were capped at 16\% (effective May 2019), rates varied from 14\% in Zhejiang and Guangdong to 19\%-20\% in most other provinces (ADB 2019); that is, richer provinces had lower rates. 


\section{F. Implementing Fiscal Reforms}

This section briefly discusses reform challenges and the sequencing of reforms.

\section{Challenges}

As discussed earlier, a three-pronged approach to reforming central-local government fiscal relations is needed: shifting some expenditure responsibilities to central government, increasing fiscal transfers to poorer provinces, and increasing tax revenue, especially at the local level. These three reform components are interrelated-and less reform in one area will require more in the others. At the same time, winners and losers depend on the specific reforms implemented.

To successfully implement fiscal reforms, more fiscal responsibilities taken over and paid for by the central government would be welcomed by local governments. But increased fiscal transfers to poorer regions will not be supported by richer ones if this ends up at their expense. The situation is the opposite for enhancing the tax revenue of local governments by granting them limited tax autonomy. Here, local governments with a higher tax base will profit disproportionally. Because of this, the central government will need to carefully manage the tax autonomy of local governments-and compensate disadvantaged ones to avoid an increase in spatial inequality.

Overall fiscal revenue is currently not enough to finance overall government expenditure. A key requirement for successful fiscal reforms is the mobilization of domestic resources. Higher contributions will need to mainly come from individuals (not firms) via a recurrent property tax and higher PIT collection, both of which are unpopular. The accountability of local governments for delivering basic public services will need strengthening to ensure that funds are properly used.

\section{Reform sequencing}

Mobilizing additional tax revenue should be among the first steps. Concurrently, the newly implemented transfer system can be refined, and practical experience gained from delineating joint responsibilities, especially for basic public services. Improving budget management at the local level will be essential for measuring the delivery of these services and for better targeting transfers.

Because the PRC's fiscally poor local governments urgently need additional funds, postponing an increase in fiscal transfers until budget management at the local level has considerably improved is not a viable option. Thus, there are conflicting goals of increasing transfers while insisting on and concurrently implementing further measures for a more efficient use of funds. Ensuring fiscal discipline at the local level if fiscal transfers are increased could be a challenge. Introducing local government own-source taxes on a broad and significant level to link revenue to expenditure would require compensating transfers to poorer regions to avoid a rise in regional disparities. The dilemma remains: supporting fiscally weaker local governments via increased transfers limits regional disparities, but makes it difficult to harden budget constraints at the local level. At the same time, regional disparities rise when tying local fiscal expenditure to local fiscal revenue via own-source taxes to harden budget constraints and increase local government accountability. But gradual improvements can be achieved with the central government centralizing some fiscal functions, strengthening budget management at the local level, and increasing transfers supporting the convergence of living standards across the country. 


\section{SUMMARY OF RECOMMENDATIONS}

Table 4 summarizes the recommendations to help reduce inequality through taxation reforms and changes to central-local government fiscal relations.

Table 4: Summary of Recommendations for Tax and Fiscal Reforms

\begin{tabular}{|c|c|c|}
\hline Item & Challenge & Recommendation \\
\hline \multicolumn{3}{|l|}{ Taxation } \\
\hline \multirow[t]{3}{*}{$\begin{array}{l}\text { Further personal income } \\
\operatorname{tax}(\mathrm{PIT}) \text { reforms }\end{array}$} & Weak tax base & $\begin{array}{l}\text { - Include individual business income, pensions, and } \\
\text { annuities into comprehensive income } \\
\text { - Tax capital gains as part of personal income } \\
\text { - Consolidate and cap special deductions }\end{array}$ \\
\hline & Low progressivity & $\begin{array}{l}\text { - Merge more income categories into comprehensive } \\
\text { income } \\
\text { - Subject income currently taxed at a flat rate (e.g., capital } \\
\text { income) to progressive rates }\end{array}$ \\
\hline & Low tax compliance & $\begin{array}{l}\text { - Establish a unified and national taxpayer database } \\
\text { - Withhold taxes at least in part at source, where possible }\end{array}$ \\
\hline \multirow[t]{3}{*}{$\begin{array}{l}\text { Roll out nationwide } \\
\text { recurrent property tax }\end{array}$} & $\begin{array}{l}\text { No legal basis for local } \\
\text { government to levy } \\
\text { property tax }\end{array}$ & $\begin{array}{l}\text { Delegate specific taxation powers and responsibilities to } \\
\text { local governments with limits set by the central gov't }\end{array}$ \\
\hline & $\begin{array}{l}\text { Lack of a nationally } \\
\text { standardized tax base } \\
\text { and tax rates }\end{array}$ & $\begin{array}{l}\text { Define a nationally standardized tax base using an area- } \\
\text { based valuation system based on size, location, use, and, } \\
\text { potentially, the age of the building } \\
\text { - Start with a moderate unified tax rate with few exemptions } \\
\text { - Possibly move to a valuation-based system later }\end{array}$ \\
\hline & $\begin{array}{l}\text { Weak local government tax } \\
\text { administration capacity }\end{array}$ & $\begin{array}{l}\text { Enable local gov't to use the property registry for valuing } \\
\text { property }\end{array}$ \\
\hline \multirow[t]{2}{*}{$\begin{array}{l}\text { Inheritance and } \\
\text { gift taxes }\end{array}$} & $\begin{array}{l}\text { Income is taxed, wealth } \\
\text { is not }\end{array}$ & $\begin{array}{l}\text { - Levy inheritance and gift taxes } \\
\text { - Nationwide rollout of a recurrent property tax }\end{array}$ \\
\hline & $\begin{array}{l}\text { Unchecked wealth } \\
\text { accumulation and } \\
\text { concentration }\end{array}$ & $\begin{array}{l}\text { - Introduce inheritance and gift taxes at progressive rates } \\
\text { beyond specific tax-free amounts for close relatives } \\
\text { - Levy property taxes that reflect the proxied property } \\
\text { value }\end{array}$ \\
\hline \multicolumn{3}{|c|}{ Central-local government fiscal relations } \\
\hline \multirow[t]{2}{*}{$\begin{array}{l}\text { Fiscal expenditure } \\
\text { responsibilities }\end{array}$} & Suboptimal assignments & $\begin{array}{l}\text { - Pensions and unemployment insurance should be elevated } \\
\text { to the central gov't, including their financing }\end{array}$ \\
\hline & $\begin{array}{l}\text { Unclear responsibilities or } \\
\text { mismatch in financing }\end{array}$ & $\begin{array}{l}\text { - Expenditure responsibilities should be clearly delineated, } \\
\text { and the scope of joint responsibilities reduced } \\
\text { - For some basic services, e.g., primary health care services } \\
\text { that could be better provided at the local level, the central } \\
\text { gov't should increase transfers to enable local gov'ts to } \\
\text { provide them at a sufficiently high standard }\end{array}$ \\
\hline
\end{tabular}




\begin{tabular}{|c|c|c|}
\hline Item & Challenge & Recommendation \\
\hline \multirow[t]{2}{*}{ Fiscal transfers } & Insufficient equalization & $\begin{array}{l}\text { - Increase the level of general transfers from the central gov't } \\
\text { to local gov'ts to advance equalization } \\
\text { - Increase transfers to poorer provinces (shift in priorities) } \\
\text { - Increase shared-function transfers to poorer provinces } \\
\text { (support to improve basic public services) }\end{array}$ \\
\hline & $\begin{array}{l}\text { Weak accountability at the } \\
\text { local level }\end{array}$ & $\begin{array}{l}\text { - Evaluate local gov't public service delivery } \\
\text { - Enhance budget management and transparency on local } \\
\text { gov't level (information, evaluation) } \\
\text { - } \text { Formalize intra-provincial transfers } \\
\text { - Roll out a property tax as own-source revenue at the local } \\
\text { level }\end{array}$ \\
\hline $\begin{array}{l}\text { Strengthening local gov't } \\
\text { fiscal revenue }\end{array}$ & $\begin{array}{l}\text { Insufficient local gov't tax } \\
\text { revenue }\end{array}$ & $\begin{array}{l}\text { - Roll out a nationwide recurrent local property tax as own- } \\
\text { source revenue at the local level } \\
\text { Broaden the tax base of PIT and increase its progressivity, } \\
\text { thereby increasing local gov't tax revenue } \\
\text { - Levy inheritance and gift taxes, with revenue shared } \\
\text { between the central and local gov'ts } \\
\text { - Consider levying a surcharge on PIT (and compensate } \\
\text { those provinces that only gain little additional revenue } \\
\text { from the surcharge) and potentially revisit the tax sharing } \\
\text { system to fine-tune local gov'ts PIT revenue }\end{array}$ \\
\hline
\end{tabular}

Source: Author. 


\section{REFERENCES}

ADB (Asian Development Bank). 2014a. Challenges and Opportunities of Population Aging in the People's Republic of China. Observations and Suggestions. No. 2014-3. Manila.

_. 2014b. Money Matters Local Government Finance in the People's Republic of China. Manila.

- 2014c. Property Taxation in the People's Republic of China. Observations and Suggestions. No. 2014-01. Manila.

- 2015a. Asian Development Outlook: Financing Asia's Future Growth. Country chapter on the People's Republic of China. Manila.

—. 2015b. Fiscal Decentralization in the PRC. Observations and Suggestions. No. 2015-01. Manila.

- 2016. Reducing Income Inequality in the People's Republic of China. Observations and Suggestions. No. 2. Manila.

- 2019. Asian Development Outlook 2019: Strengthening Disaster Resilience. Country chapter on the People's Republic of China. Manila.

- 2020a. Streamlining Pension Contributions in the People's Republic of China. Observations and Suggestions. No. 2020-01. Manila.

- 2020b. Reforming the Personal Income Tax System in the People's Republic of China. Observations and Suggestions. No. 2020-02. Manila.

_.2021a. Poverty, Vulnerability, and Fiscal Sustainability in the People's Republic of China. Manila.

_. 2021b. Asian Development Outlook 2021: Financing a Green and Inclusive Recovery. Country chapter on the People's Republic of China. Manila.

Ahmad, E. 2019. Governance and Decentralization Options for China. Paper prepared for the World Bank and the Chinese Academy of Fiscal Science.

Ahmad, E., I. Neuweg, and N. Stern. 2018. Policies for Structural Reform in China: Domestic Rebalancing for Strong Sustainable and Inclusive Growth within and beyond China. Paper presented at the 2018 China Development Forum. Beijing.

Ahmad, E., and H. van Rijn. 2020. The Role of Local Governments in Driving High-Quality Growth in the People's Republic of China. ADB East Asia Working Paper Series. No. 31. Manila.

Arora, V., and J. Norregaard. 1997. Intergovernmental Fiscal Relations: The Chinese System in Perspective. IMF Working Paper. WP/97/129. Washington, DC: International Monetary Fund.

Asen, E. 2020. Corporate Tax Rates around the World, 2020. Fiscal Fact. No. 735. Washington, DC: Tax Foundation.

Bahl, R. 2019. Rebalancing the Economy and Reforming the Fiscal System of the People's Republic of China. Governance Briefs. No 34. Manila: Asian Development Bank. 
Bahl, R., C. Goh, and B. Qiao. 2014. Reforming the Public Finance System to Fit a More Urbanized China. Manila: Asian Development Bank.

Bastagli, F., D. Coady, and S. Gupta. 2015. Fiscal Redistribution in Developing Countries: Overview of Policy Issues and Options. In B. Clements et al., eds. Inequality and Fiscal Policy 2015. Washington, DC: International Monetary Fund.

BIS (Bank for International Settlements). 2021. Annual Economic Report. Basel.

Boadway, R., and L. Eyraud. 2018. Designing Sound Fiscal Relations across Government Levels in Decentralized Countries. IMF Working Paper. WP/18/271. Washington, DC: International Monetary Fund.

Brandt, L., et al. 2020. China's Productivity Slowdown and Future Growth Potential. Policy Research Working Paper. No. 9298. Washington, DC: World Bank.

Chan, J. 2019. New Development: China Renews Reform of Central-Local Fiscal Relations and Provides for Basic National Public Services. Public Money and Management. 39 (1). pp. 164-69.

Chen, X., B. Huang, and S. Li. 2017. Population Aging and Inequality: Evidence from the People's Republic of China. ADBI Working Paper Series. No. 794. Tokyo: Asian Development Bank Institute.

Coady, D., R. de Mooij, and B. Shang. 2015. Inequality and Fiscal Redistribution in Advanced Economies. In B. Clements et al., eds. Inequality and Fiscal Policy 2015. Washington, DC: International Monetary Fund.

Credit Suisse. 2021. Global Wealth Report. 2020. Credit Suisse Research Institute.

Das, D., and P. N'Diaye. Chronicle of a Decline Foretold: Has China Reached the Lewis Turning Point? IMF Working Paper. WP/13/26. Washington, DC: International Monetary Fund.

Dollar, D., and B. Hofman. 2006. Intergovernmental Fiscal Reforms, Expenditure Assignment, and Governance. Paper presented at the Roundtable Conference on Public Finance for a Harmonious Society. 27-28 June. Beijing.

Fan, Z., and G. Wan. 2017. The Fiscal Risk of Local Government Revenue in the People's Republic of China. In N. Yoshino and P. Morgan, eds. Central and Local Government Relations in Asia. Achieving Fiscal Sustainability. Cheltenham, United Kingdom: Edward Elgar Publishing.

Glenn, E., and S. Qiu. 2018. China Plans Income Tax Breaks to Boost Consumption. Thomson Reuters. 31 August. https://www.reuters.com/article/us-china-economy-tax-idUSKCN1LG18E.

Goodhart, C., and M. Pradhan. 2020. The Great Demographic Reversal: Ageing Societies, Waning Inequality, and an Inflation Revival. London: Palgrave Macmillan.

Gustafsson, B., S. Li, and H. Sato. 2014. Data for Studying Earnings, the Distribution of Household Income and Poverty in China. IZA Discussion Paper Series. No. 8244. Bonn: Institute for Labor Economics.

IMF (International Monetary Fund). 2018. The People's Republic of China. Technical Assistance Report: Tax Policy and Employment Creation. IMF Country Report. No.18/92. Washington, DC. 
Inchauste, G., and N. Lustig. 2017. Overview: Fiscal Policy and Redistribution. In G. Inchauste and N. Lustig, eds. The Distributional Impact of Taxes-Evidence from Eight Low- and Middle-Income Countries. Washington, DC: World Bank.

Jain-Chandra, S., et al. 2018. Inequality in China-Trends, Drivers and Policy Remedies. IMF Working Paper. WP/18/127. Washington, DC: International Monetary Fund.

Jin, H., and X. Qian. 2020. How the Chinese Government Has Done with Public Health from the Perspective of the Evaluation and Comparison about Public-Health Expenditure. International Journal of Environmental Research and Public Health 17 (24).

Kanbur, R., Y. Wang, and X. Zhang. 2020. The Great Chinese Inequality Turnaround. Journal of Comparative Economics. 49 (2). pp. 467-82. https://doi.org/10.1016/j.jce.2020.10.001.

Lam, W. R., X. Liu, and A. Schipke. 2015. China's Labor Market in the "New Normal." IMF Working Paper. WP/15/151. Washington, DC: International Monetary Fund.

Lam, W. R., and P. Wingender. 2015. China: How Can Revenue Reform Contribute to Inclusive and Sustainable Growth. IMF Working Paper. WP/15/66. Washington, DC: International Monetary Fund.

Lardy, N., and T. Huang. 2020. China's Weak Social Safety Net Will Dampen Its Economic Recovery. China Economic Watch. 4 May. Washington, DC: Peterson Institute for International Economics.

Leng, S. 2020. Coronavirus: China's Income Inequality Could Expand in 2020 as Outbreak Rattles World's No 2 Economy. SCMP. 17 March.

Li, C., and Y. Fan. 2020. Housing Wealth Inequality in Urban China: The Transition from Welfare Allocation to Market Differentiation. Journal of Chinese Sociology (7).

Li, S., T. Sicular, and F. Tarp. 2018. Inequality in China. Development, Transition and Policy. UNU-WIDER Working Paper. No. 2018/174. Helsinki: United Nations World Institute for Development Economic Research.

Li, Q., S. Li, and H. Wan. 2020. Top Incomes in China: Data Collection and the Impact on Income Inequality. China Economic Review. 62 (August).

Li, S., M. Zhu, and P. Zhan. 2017. Redistributive Effects of the Social Security System in China [in Chinese]. Chinese Social Security Review. 1 (4).

Liu, Y., J. Martinez-Vazquez, and A. Wu. 2016. Fiscal Decentralization, Equalization, and IntraProvincial Inequality in China. Georgia State University, Andrew Young School of Policy Studies. Working Paper. No. 14-32. Atlanta, GA: International Center for Public Policy.

Liu, Y., J. Martinez-Vazquez, and B. Qiao. 2014. Falling Short: Intergovernmental Transfers in China. Georgia State University, Andrew Young School of Policy Studies. Working Paper. No. 1425. Atlanta, GA: International Center for Public Policy.

Lustig, N., and Y. Wang. 2020. The Impact of Taxes and Transfers on Income Inequality, Poverty, and the Urban-Rural and Regional Income Gaps in China. Working Paper. No 547. Washington, DC: Center for Global Development. 
Martinez-Vazquez, J., and B. Qiao. 2010. Expenditure Assignments in China. Georgia State University, Andrew Young School of Policy Studies. Working Paper. No. 10-28. Atlanta, GA: International Studies Program.

Milanovic, B. 2016. Increasing Capital Income Share and its Effect on Personal Income Inequality. LIS Working Paper Series. No. 663. Luxembourg: Luxembourg Income Study.

Mooij, R. de., W. Lam, and P. Wingender. 2017. Modernizing the Tax Policy Regime. In W. Lam, M. Rodlauer, and A. Schipke, eds. Modernizing China-Investing in Soft Infrastructure. Washington, DC: International Monetary Fund.

Morgan, P., and L. Trinh. 2017. Frameworks for Central-Local Government Relations and Fiscal Sustainability. In N. Yoshino and P. Morgan, eds. Central and Local Government Relations in Asia. Achieving Fiscal Sustainability. Cheltenham, United Kingdom: Edward Elgar Publishing.

Norregaard, J. 2013. Taxing Immovable Property Revenue Potential and Implementation Challenges. IMF Working Paper. WP/13/129. Washington, DC: International Monetary Fund.

OECD (Organisation for Economic Co-operation and Development). 2017. OECD Economic Surveys: China. Paris.

-2018. Achieving Inclusive Growth in the Face of Digital Transformation and the Future of Work. Paris. https://www.oecd.org/g20/OECD_Achieving\%20inclusive\%20growth\%20in\%20the\%20 face\%20of\%20FoW.pdf.

_. 2019. OECD Economic Surveys: China. Paris.

- 2020. Revenue Statistics 1965-2019. Paris.

- 2021a. Inheritance Taxation in OECD Countries. Paris.

- 2021b. Government at a Glance. Paris.

- 2021c. Revenue Statistics in Asia and the Pacific 2021-China. Paris. https://www.oecd.org/tax/ tax-policy/revenue-statistics-asia-and-pacific-china.pdf.

—. n.d. HM1.2 House Prices. Paris. https://www.oecd.org/els/family/HM1-2-Housing-prices.pdf.

OECD (Organisation for Economic Co-operation and Development) and KIPF (Korean Institute of Public Finance). 2016. Fiscal Federalism 2026: Making Decentralization Work. OECD Fiscal Federalism Studies. Paris.

OECD (Organisation for Economic Co-operation and Development) and UCLG (United Cities and Local Governments). 2019. Report of the World Observatory on Subnational Government Finance and Investment-Key Findings. Paris.

Piketty, T., L. Yang, and G. Zucman. 2019. Capital Accumulation, Private Property and Rising Inequality in China, 1978-2015. American Economic Review. 109 (7). pp. 2469-96.

State Council. 2018a. Notice of the Reform Plan for the Division of Fiscal Powers and Expenditure Responsibilities in the Field of Basic Public Service. http://www.gov.cn/zhengce/content/ 2018-02/08/content_5264904.htm [in Chinese]. 
2 2018b. Notice of the Reform Plan for the Division of Fiscal Powers and Expenditure Responsibilities in the Field of Health. http://www.gov.cn/zhengce/content/2018-08/13/ content_5313489.htm [in Chinese].

2019a. Notice of the Reform Plan for the Division of Fiscal Powers and Expenditure Responsibilities in the Field of Technology. http://www.gov.cn/zhengce/content/2019-05/31/ content_5396370.htm [in Chinese].

_ 2019b. State Council Issues Guideline on Education Finance Duties. http://english.www.gov.cn/ policies/latest_releases/2019/06/03/content_281476697092588.htm.

- 2019c. State Council Issues Guideline on Transportation Finance Duties. http://english.www. gov.cn/policies/latestreleases/201907/10/content_WS5d25e875c6d02ed9d94f27a8.html.

- 2020a. State Council Issues Guideline on Fiscal Duties in Ecological Environment. http://english.www.gov.cn/policies/latestreleases/202006/12/content_ WS5ee3890fc6d0a6946639bf84.html.

—. 2020b. State Council Issues Guideline on Fiscal Duties in Public Culture. http://english.www. gov.cn/policies/latestreleases/202006/23/content_WS5ef1f853c6d0a6946639c990.html.

- 2020c. Govt Defines Financial Powers, Spending Responsibilities in Emergency Rescue. http://english.www.gov.cn/policies/latestreleases/202007/24/content_ WS5f1c2bb4c6d029c1c2636acc.html.

—. 2020d. Fiscal Powers and Expenditure Responsibilities Clarified in Natural Resources. http://english.www.gov.cn/policies/latestreleases/202007/11/content_ WS5f09812ec6d06c4091250c2e.html.

Qiao, B., et al. (forthcoming). Critical Issues for Fiscal Reform in the People's Republic of China: Tacking the Root Causes. Manila: Asian Development Bank.

Ravallion, M., and S. Chen. 2007. China's (uneven) Progress against Poverty. Journal of Development Economics. 82 (1). pp. 1-42.

Rozelle, S., et al. 2020. Moving Beyond Lewis: Employment and Wage Trends in China's High-and LowSkilled Industries and the Emergence of an Era of Polarization. Comparative Economic Studies. 62. 555-589.

Sow, M., and I. Razafimahefa. 2017. Fiscal Decentralization and Fiscal Policy Performance. IMF Working Paper. WP/17/64. Washington, DC: International Monetary Fund.

The Economist. 2021a. Vanguard of the Non-Working Class-At 54, China's Average Retirement Age Is Too Low. 26 June.

The Economist. 2021b. Red Lines, Grey Rhinos and Big Mountain-China's Bid to Stabilise Its Property Market Is Causing Jitters. 4 September.

Wan, G., C. Wang, and Y. Wu. 2021. What Drove Housing Wealth Inequality in China? China and World Economy. 29 (1). pp. 32-60. 
Wang, C., et al. 2017. Aging and Inequality: The Perspective of Labor Income Share. ADBI Working Paper Series. No. 764. Tokyo: Asian Development Bank Institute.

Wang, X., and R. Herd. 2013. The System of Revenue Sharing and Fiscal Transfers in China. OECD Economics Department Working Papers. No.1030. Paris: Organisation for Economic Co-operation and Development.

Wingender, P. 2018. Intergovernmental Fiscal Reform in China. IMF Working Paper. WP/18/88. Washington, DC: International Monetary Fund.

Wong, C. 2020. Managing Across Levels of Government: The Challenge of Pension Reform in China. In K. Jim and S. Dougherty, eds. Ageing and Fiscal Challenges across Levels of Government. OECD Fiscal Federalism Studies. Paris: Organisation for Economic Cooperation and Development.

World Bank. 2018. Fiscal Policies for Rebalancing. China Economic Update. December. Washington, DC.

- 2020. From Recovery to Rebalancing China's Economy in 2021. China Economic Update, Special Topic: Growing Together or Growing Apart? Regional Disparity and Convergence in China. December. Washington, DC.

- 2021. Beyond the Recovery. Charting a Green and Inclusive Growth Path. China Economic Update, Special Topic: Extreme Poverty Has Been Eliminated. What Comes Next? June. Washington, DC.

World Bank and DRC (Development Research Center of the State Council). 2019. Innovative China: New Drivers of Growth. Washington, DC.

Wu, Y., et al. 2017. Transfer Payment Structure and Local Government Fiscal Efficiency: Evidence from China. China Finance and Economic Review. 5 (12).

Xie, Y., and Y. Jin. 2015. Household Wealth in China. China Sociological Review. 47(3). pp. 203-229.

Xinhua. 2021. China to Pilot Property Tax Reforms. 23 October. http://www.news.cn/english/202110/23/c_1310264479.htm

Yu, S., and T. Mitchell. 2021. China's Demographic Challenge Looms Large. Financial Times. 17 May.

Yu, S., and Y. Yang. 2020. The Widening Wealth Gap. Financial Times. 19 August.

Zhang, P., L. Sun, and C. Zhang. 2020. Understanding the Role of Homeownership in Wealth Inequality: Evidence from Urban China (1990-2018). SSRN Reports. 9 October. https://ssrn.com/abstract=3707918.

Zhang, Q., and S. Li. 2017. Key Issues of Central and Local Government Finance in the People's Republic of China. In N. Yoshino and P. Morgan, eds. Central and Local Government Relations in Asia: Achieving Fiscal Sustainability. Cheltenham, United Kingdom: Edward Elgar Publishing.

Zhu, M., L. Zhang, and D. Peng. 2019. China's Productivity Convergence and Growth Potential-A Stocktaking and Sectoral Approach. IMF Working Paper. WP/19/263. Washington, DC: International Monetary Fund. 
Zhuang, J. and L. Shi. 2016. Understanding Recent Trends in Income Inequality in the People's Republic of China. ADB Economics Working Paper Series. No. 489. Manila: Asian Development Bank. 


\section{Reducing Inequality in the People's Republic of China through Tax and Fiscal Reforms}

Income inequality after redistribution is high in the People's Republic of China. Wealth inequality is much starker than it was 2 decades ago, and differences in gross regional product per capita between provinces remain sizable. This paper analyzes trends in and the drivers of inequality and identifies needed reforms in the tax system and central-local government fiscal relations to reduce inequality. Taking into account recent changes to the tax system and fiscal relations, the paper offers policy recommendations to reduce inequality by strengthening redistribution mechanisms.

\section{About the Asian Development Bank}

ADB is committed to achieving a prosperous, inclusive, resilient, and sustainable Asia and the Pacific, while sustaining its efforts to eradicate extreme poverty. Established in 1966, it is owned by 68 members -49 from the region. Its main instruments for helping its developing member countries are policy dialogue, loans, equity investments, guarantees, grants, and technical assistance. 